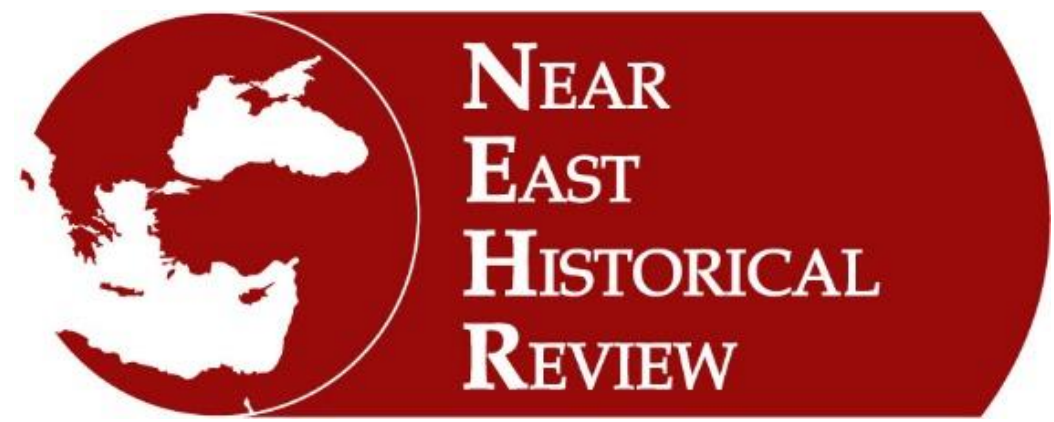

\title{
H. 1261/M. 1845 TARİHLİ NÜFUS SAYIMINA GÖRE KARAOSMANOĞLU YAKUP PAŞA YÖNETIMIINDE AYDIN GÜZELHISARI
}

Güzelhisar of Aydin Under The Administration of Karaosmanoğlu Yakup Passa According to The Census of 1845/1261

Dr. Öğr. Üyesi Mehmet Başaran - Doç. Dr. Aysun Sarıbey Haykıran Aydın Adnan Menderes Üniversitesi, Türkiye / Aydın Adnan Menderes Üniversitesi, Türkiye

e-mail: mbasaran@adu.edu.tr / aysunsaribey@gmail.com

ORCID ID: orcid.org/ 0000-0001-9178-7117 / orcid.org/ 0000-0002-1016-7707

Near East Historical Review

10/2, April - Nisan 2020

e-ISSN: 2717-6363 (Online)

www.nehrreview.com

\author{
Article Type-Makale Türü : Research Article/Araştırma Makalesi \\ Received Date - Geliş Tarihi : $\quad 30.02 .2020$ \\ Accepted Date - Kabul Tarihi : 15.04 .2020 \\ Pages - Sayfa : 59-128 \\ doi : http://dx.doi.org/10.29228/nehrreview.43002
}

\footnotetext{
Citation-Atuf : Mehmet Başaran - Aysun Sarıbey Haykıran, "H. 1261/M. 1845 Tarihli Nüfus Sayımına Göre Karaosmanoğlu Yakup Paşa Yönetiminde Aydın Güzelhisar1", Near East Historical Review, 10/2, April 2020, pp. 59-128
} 



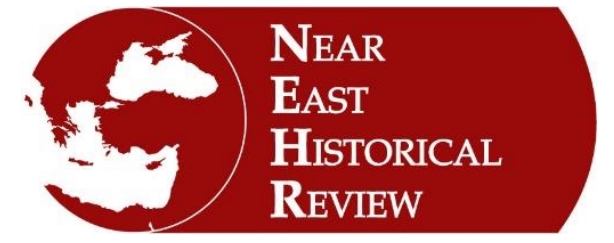

Near $\boldsymbol{E}$ ast $\boldsymbol{H}$ istorical Review

10/2, April - Nisan 2020

$59-128$

\title{
H. 1261/M. 1845 TARİHLİ NÜFUS SAYIMINA GÖRE KARAOSMANOĞLU YAKUP PAȘA YÖNETIMINDE AYDIN GÜZELHISARI
}

\author{
Güzelhisar of Aydın Under The Administration of Karaosmanoğlu Yakup Paşa According to \\ The Census of 1845/1261
}

\author{
Dr. Öğr. Üyesi Mehmet Başaran - Doç. Dr. Aysun Sarıbey Haykıran \\ Aydın Adnan Menderes Üniversitesi, Türkiye / Aydın Adnan Menderes Üniversitesi, Türkiye
}

\section{$\ddot{O} \mathbf{z}$}

Osmanlı İmparatorluğu'nda modern anlamda ilk nüfus sayımı, Yeniçeri Ocağı'nın kaldırılmasından sonra yerine kurulan yeni ordunun asker ihtiyacının karşılanması ve mali durumun tespitine temel oluşturmak amaciyla 1831 tarihinde II. Mahmut döneminde yapılmıştır. 1844, 1852, 1885 ve 1907 yılları başta olmak üzere belirli periyotlarla devam eden bu sayımlarla İmparatorluk coğrafyasındaki Müslim ve Gayrimüslim erkek nüfus kayıt altına alınmıştır.

$\mathrm{Bu}$ çalışmada, XIX. yüzyılın ilk yarısında Karaosmanoğlu Yakup Paşa'nın müşirliği sırasında tutulan ve Aydın Güzelhisar Kazası'na ait H. 1261/M. 1845 tarihinde yapılan nüfus sayımı sonuçlarını içeren Cumhurbaşkanlığı Devlet Arşivleri Osmanlı Arşivi’nde 3013 numara ile kayıtlı nüfus defterindeki veriler değerlendirilecektir. Diğer nüfus defterlerinden farklı olarak bu defterde, Karaosmanoğlu Yakup Paşa'nın mahiyetindeki kişilerle, Aydın Güzelhisarı defterdarı, hâkimi ve zabtiye teşkilatındaki süvari ve piyadegana ait olmak üzere Kaza idaresinde görevli idari, mali ve askeri kadrolarda görevli kişilerin sayımı yapılmıştır. Ayrıca defterde sayımın yapıldı $\breve{1}$ tarihte Aydın Güzelhisar Kazası'ndaki medreseler ve hanlarda kalan kişiler de kayıt altına alınmıştır. Yine defterin başka bir özelliği, Aydın Güzelhisar Kazası'ndaki kahve ve dükkânlar ile kazaya bağlı Hacı Ali Obası, Kürtler, Umurlu ve Serçe köylerindeki bekaran nüfusun nitelik ve niceliklerine ait verilerin de yer almasıdır. Tanzimat'ın hemen sonrasına ait bu nüfus defterinden elde edilecek veriler, Aydın Güzelhisar Kazası'nın idari, sosyo-ekonomik, askeri ve ilmi yönüne ilişkin birinci elden bilgilere ulaşma imkânı sunmaktadır.

Anahtar Kelimeler: Aydın Güzelhisarı, Karaosmanoğlu Yakup Paşa, Deftardar, Medrese, Han.

\begin{abstract}
The first census in the modern meaning in the history of the Ottoman Empire was in the reign of Mahmud II in 1831 following the abolishment of the Janissary army, in order to retain the fiscal situation of the state and to provide the need of warrior for the new army, established instead of the Janissaries. The Muslim and the non-Muslim men of the empire were officially registered by the census of 1844, 1852, 1885 and 1907.
\end{abstract}

In this study, the official registers in the Turkish Presidency State Archives, Department of Ottoman Archives, No. 3013 according to the census of 1845 in Aydin under the administration of Karaosmanoğlu Yakup Paşa are evaluated. Unlike the other boks, in this register those can be found as follows: The civil cervants who were on duty with Yakup Paşa, and the official administrative, financial and militarial servants of the Aydin governorate like Defterdar (Revenue Officier), Judge, Zabtiye (policemen) as süvari and piyadegana. Moreover, the people who were staying in the madrasha and the caravanserai in Aydın were also taken into registration. As another characteristics of the book, the single men in the villages like Hacı Ali Obası, Kürtler, Umurlu and Serçe were taken into registration. The data that would be collected from this registration book will be useful to reach new primary information about the socio-economic, cultural and military lives in Aydin at that period.

Keywords: Güzelhisar of Aydın, Karaosmanoğlu Yakup Paşa, Defterdar, Madrasha, Caravanserai 


\section{Giriş}

Dirlik dağıtımı ve vergilerin toplatılmasına yönelik XV. ve XVI. yüzyıllarda gerçekleştirilen arazi tahrirlerinin amacı dirlik sistemi içinde devlet görevlerine tahsis edilmiş olan gelirlerin tespit edilmesidir. $\mathrm{Bu}$ amaç doğrultusunda haslar, zeametler ve tımarlar başta olmak üzere tek tek bütün dirlikler tahsis edilmiş olan kişilerin isimleriyle ve hisseleriyle yazılmıştır. ${ }^{1} \mathrm{Bu}$ sayımların sonucunu içeren bilgilerin kaydedildiği tapu tahrir defterleri de Osmanlı sosyo-ekonomik yapısının ortaya çıkarılmasında geçmişten günümüze ulaşan birinci elden kaynak olma özelliği göstermektedir. XVI. yüzyılın sonlarında iki cepheli savaşlar ile Celali İsyanları ile birlikte başlayan süreçte Anadolu köylüsünün toprağını terk etmesisiniz neticesinde önemini kaybeden tımar sistemiyle birlikte klasik tahrir usulünden vazgeçilmiştir. Avarız vergisinin merkezi maliye açısından önem kazandığı bu yeni dönemde avarız tahrirleri yapılmaya başlamıştır. ${ }^{2}$ XVI. yüzyılın sonlarından XVIII. yüzyılın sonlarına kadar devam eden avarız tahrirlerinden sonra dünyanın birçok yerinde başlayan modern anlamdaki nüfus sayımlarının ilk uygulamalarına Osmanlı Devleti'nde II. Mahmut döneminde rastlanılmaktadır. 1831 y1lındaki modern anlamdaki ilk nüfus sayımdan sonra belirli aralıklarla devletin vergi kaynaklarının tespiti ve Yeniçeri Ocağı'nın kaldırılmasından sonra yeni kurulan ordunun asker ihtiyacının karşılanmasına yönelik olarak 1844, 1852, 1885 ve 1907 yılları başta olmak üzere ülke çapında nüfus sayımları gerçekleştirilmiştir. ${ }^{3}$

Osmanlı dönemi yerleşim birimlerinin sosyal, ekonomik ve etnik durumları hakkında önemli bilgiler içeren nüfus defterleri “T.C. Cumhurbaşkanlı̆̆ Devlet Arşivleri Başkanlığ ”"nda "nüfus defterleri" kataloğunda bulunmaktadır. İçerik olarak incelendiğinde nüfus defterlerinde nüfus sayımın yapıldığı yerleşim biriminin adıyla o yerleşim birimindeki kişilerin isimleri, lakapları, meslekleri, fiziksel özellikleri ve yaşlarına ilişkin bilgilerin yanı sıra genelde kırmızı mürekkep ile "tevellüd", "fevt" veya "reft" gibi notlar düşülerek kişilerin doğum, ölüm ve sürgün gibi özellikleri de belirtilmiştir.

Çalışmanın temelini oluşturan H.1261/M.1845 tarihli NFS.d.. 3013 numaralı Aydın Eyaleti'nin Aydın Sancăğ'nın merkezi konumunda olan Güzelhisar Kazası'nın Müslim defteri, diğer nüfus defterlerinden farklı özelliklere sahiptir. 25X69,5 ebatında ve 27 sayfadan oluşan nüfus defterinden, Güzelhisar Kazası dahilindeki erkek nüfusunun yerine XIX. yüzyılın ilk yarısında Aydın Eyaleti'nin yönetiminde önemli rol oynamış ve nüfus sayımın yapıldığı dönemde de Aydın müşiri unvanıyla Aydın'ın yönetici konumunda bulunan Karaosmanoğlu Yakup Paşa ve maiyeti ile Aydın Defterdarı ve Zaptiye çalışanları gibi resmi görevliler hakkında bilgi sahibi olunabilmektedir. Defterin ilk kısmında şehrin bürokratik yapılanmasını aydınlatıcı manada idari kadro hakkındaki bilgiler verildiği gibi Kaza dahilinde faal olan medreseler ile bunların müderris ve talebeleri ile bunun yanında mevcut hanların isimleri ve burada kalanların meslekleri, nereden ve niçin geldikleri ile detaylı bilgilere de ulaşılmaktadır. Bu nedenle 1845 tarihli nüfus sayımı sonuçlarını içeren nüfus defteri, Aydın Güzelhisar Kazası’nın idari yapısı, ilmi hareketliliği ile sosyo-ekonomik durumunu aydınlatan önemli bir kaynak olma özelliğini taşımaktadır.

\footnotetext{
${ }^{1}$ Ayrıntılı bilgi için bakınız. Ömer Lütfü Barkan, "Türkiye'de İmparatorluk Devirlerinin Nüfus ve Arazi Tahrirleri ve Hakana Mahsus İstatistik Defterleri", Ï̈̈ İktisat Fakültesi Mecmuast, 2/1, 1940-41, ss. 20-59; Mehmet Öz, "Tahrir ", DİA, c. 39, İstanbul 2010, ss. 425-429, Erhan Afyoncu, Osmanlı Devlet Teşkilatında Defterhane-i Amire (XVII- XVIII. Yüzyıllar, Ankara 2014,), Türk Tarih Kurumu, Ankara 2014; Hilal Ortaç, Tapu Tahrir Defterlerine Göre 16. Yüzyılda Güzelhisar, Aliağa Belediyesi Kültür Yayınları, Ankara 2018.

${ }^{2}$ Mehmet Öz, a.g.m. s. 428.

${ }^{3}$ Bu konuda daha geniş bilgi için bakınız: Enver Ziya Karal, Osmanlı Imparatorluğu'nda İlk Nüfus Sayımı 1831, Devlet İstatistik Enstitüsü, Ankara 1997; Cem Behar, “Osmanlı Nüfus İstatistikleri ve 1831 Sonras1 Modernleşmesi”, Osmanlı Devleti’nde Bilgi ve İstatistik, (Ed. H. İnalcık-Ş. Pamuk), Devlet İstatistik Enstitüsü, Ankara 2000.
}

Near East Historical Review www.nehrreview.com 


\section{Güzelhisar-1 Aydın}

Eskiçağların Tralles'i Aydınoğulları Beyliği'nin Güzelhisar'1 ve Osmanlı dönemindeki ismiyle Güzelhisar-1 Aydın Kazası sahip olduğu bereketli toprakları sayesinde tarihin her döneminde önemini korumuştur. Sahip olduğu yer altı ve yerüstü kaynaklarıyla çok sayıda medeniyete ev sahipliği yapmış olan Aydın Güzelhisarı tarih boyunca birçok saldırı ve işgale uğramıştır.

Aydınoğulları Beyliği zamanında Türklerin eline geçen kent, Osmanlı ile Aydınoğulları arasında el değiştirmesinin ardından II. Murat döneminde yeniden Osmanlı egemenliği altına girmiştir. ${ }^{4}$ Osmanlı yönetiminde XV. yüzyılın ortalarında yedi mahalleli bir kasaba görünümünde olan Güzelhisar Kazası, aynı yüzyılda Aydın Sancağı'nın çekim merkezi konumundaki Tire'nin gerisinde kalmıştır. ${ }^{5}$

Tarihsel süreçte giderek önem kazanan Güzelhisar, Evliya Çelebi’nin kazayı ziyaret ettiği dönem olan XVII. yüzyılın sonlarında canlı bir ticaret merkezi konumuna gelmişti. Evliya Çelebi'nin Seyahatnamesi'nde Güzelhisar'ın pazar ve çarşılarıyla hanlarından, bedestenlerinden pamuklu dokumalarından boyacılarından ve helvacı esnafindan uzun uzadıya bahsetmesi bu ticari canlılı̆̆ göstermesi bakımından önemlidir. ${ }^{6}$

XVIII. yüzyılla birlikte gelişimini devam ettiren Aydın Güzelhisarı bu dönemde vali ve muhassılların idari merkezi olmuştur. ${ }^{7}$ XVIII. yüzyıldan beri muhassıllar tarafindan yönetilen Aydın Sancağı, aynı yüzyılın sonlarından itibaren Cihanoğulları ve Karaosmanoğulları ayan ailelerinin nüfuzu altına girmiştir. Bu dönemde Manisa ve Aydın'da Karaosmanoğulları, Koçarlı ve Aydın'ın bir bölümünde Cihanoğulları, Söke ve Kuşadası'nda İlyaszadeler, Çine ve Menteşe'de Hasan Çavuşzadeler ayanlık döneminin önemli aileleriydi. ${ }^{8}$ II. Mahmut'un taşrayı merkeze bağlama çabaları sırasında ayanlara karşı yürüttügü politika, Karaosmanoğulları'ndan Hüseyin Ağa'nın 1816 yılında ölümünden sonra Aydın ve Saruhan sancaklarında bir dereceye kadar uygulama alanı bulmuştur. ${ }^{9}$ Karaosmanoğlu Hüseyin Ağa'nın ölümünden sonra merkezden atanan mutasarnıf paşalar tarafindan yönetilen Aydın, Yeniçeri Ocă̆ı'nın 1826 yılında kaldırılmasından sonra Anadolu Eyaleti’nde yapılan idari değişikliklerden de nasibini almıştır. Anadolu Eyaleti dörde bölünerek mutasarrıf paşalar veya onların atadığı mütesellimler tarafından yönetilmeye başlamıştır. İzmir, Aydın, Teke, Hamit, Saruhan ve Sığla sancaklarının birleştirilmesiyle oluşan yeni idari yapının başına Hasan Paşa getirilmiştir. ${ }^{10}$

\footnotetext{
${ }^{4}$ Himmet Akın, Aydınoğulları Tarihi Hakkında Bir Araştırma, Ankara Üniversitesi Basım Evi, Ankara 1968, s. 8182.

${ }^{5}$ Suraiya Faroqhi, "Sixteenth Century Periodic Markets in Various Anatolian Sancaks: İçel, Hamid, Karahisar-1 Sahib, Kütahya, Aydın, and Menteşe”, Journal of Economic and Social, History of the Orient, c. 22, S. 1, 1979, s. 61.

${ }^{6}$ Evliyâ Çelebi, Seyahatnâmesi, IX. Kitap, Yücel Dağlı, Seyit Ali Kahraman, Robert Dankoff, Yapı Kredi Yayınları İstanbul 2005, s. 78.; Olcay Pullukçuoğlu Yapucu, Modernleşme Sürecinde Bir Sancak Aydın, Kitap Yayınevi, İstanbul 2007, s. 45.

${ }^{7}$ Himmet Akın, a.g.e, 89. Ayrıca Aydın muhassıllığı için bkz. Bülent Çelik, Tanju Demir, Osmanlı Devleti'nde Birİdari- Mali Yeniden Yapılanma Örneği Aydın Muhassıllı̆̆ı (XVII. ve XVIII. Yüzyıllar), Adnan Menderes Üniversitesi Yayınları, Aydın 2010.

${ }^{8}$ Aysun Sarıbey Haykıran, Mehmet Başaran, "Modernleşme Sürecinde Aydın'da Yönetim Olgusu, Tarihsel Süreçte Aydın, Ed. Günver Güneş, Aydın Belediyesi Kültür Yayınları, Aydın 2012, s. 171.

Konuyla ilgili ayrıntılı bilgi için bkz. Aysun Sarıbey, XIX. Yüzyılın İlk Yarısında Aydın'da Yönetim, Yayımlanmamış Yüksek Lisans Tezi, Adnan Menderes Üniversitesi, Sosyal Bilimler Enstitüsü, Aydın 2006.

9 Aysun Sarıbey Haykıran, Ayten Can Tunalı, "XIX. Yüzyılda Aydın”, Aydın İl Tarihi, Aydın İl Kültür Müdürlüğü Yayınları, Aydın 2006, s. 125-126.

10 Tuncer Baykara, Anadolu'nun Tarihi Coğrafyasına Giriş, I Anadolu'nun İdari Taksimatı, Türk Kültürü Enstitüsü Yayınları, Ankara 1988, s.119-120; Aysun Sarıbey Haykıran, "1831 Tarihli Nüfus Sayımında Aydın Güzelhisar Kazas1 Cami-, Atik Mahallesi”, Yenifikir Uluslararası Hakemli Akademik Fikir Araştırma Dergisi, S. 22 (Temmuz 2019), s. 10.
} 
1828-1829 yıllarında Aydın ve dolaylarında meydana gelen Atçalı Kel Mehmet isyanında ${ }^{11}$ yönetimi Karaosmanoğlu ailesine verilen Aydın Güzelhisarı ve çevresi 1833 yılından itibaren Mısır Valisi Mehmet Ali Paşa'nın oğlu İbrahim Paşa'nın mütesellim olarak atadığı Süleyman Bey tarafından idare edilerek adeta II. Fetret dönemini yaşamıştır. ${ }^{12}$ Mısırlı mütesellimin ayrılmasından sonra Aydın Sancağı'na muhassıl olarak Karaosmanoğlu Yakup Paşa atanmıştır.

Bilindiği üzere II. Mahmut dönemi askeri alanda yapılan önemli değişikliklerden biri de Redif teşkilatının kurulmasıdır. Yeniçeri Ocağı'nın 1826 yılında kaldırılmasından sonra askeri alanda farklı gereksinimlerin karşılanması redif teşkilatı ile gerçekleştirilmeye çalışılmış, Redif askeri teşkilatının kurulmasını emreden ferman eyalet valilerinin eline geçer geçmez, Ankara, Çankırı ve Karahisar-1 Sahib sancakları Anadolu Eyaleti'nde redif taburlarını ilk tamamlayan sancaklar olmuşlardır. Daha sonra sırasıyla H. Zilkade 1250 (M. Mart 1835) tarihinde Aydın, Saruhan ve Hamit sancaklarının da kısa bir sürede birliklerini tamamlama yoluna gittiği görülmektedir. $\mathrm{Bu}$ ortam içerisinde yukarıda da belirttiğimiz üzere Aydın muhassılı olan Karaosmanoğlu Yakup Paşa hem Manisa'ya hem de İzmir'e giderek buralarda askere alım işlemlerini tamamlamıştır. ${ }^{13}$

Mısır valisi Mehmet Ali Paşa'nın birlikleri Anadolu'dan çekildikten sonra tekrar askeri nitelikli bir idari teşkilatlanma başlamıştır. Bir bakıma eski askeri nitelikte sancak ve beylerbeylikler canlandırılarak müşirlikler oluşturulmuş, müşirliklerin başına en yüksek rütbeli asker kişi olan müşirler atanırken bunun bir alt birimi sancak karşıllğı oluşturulan ferikliklerin başında da ferik rütbeli askerler bulunmaktadır. 1836 yılındaki değişiklikler ile birlikte Aydın, Saruhan, Sığla ve Menteşe sancakları müşirlik haline getirilip, Aydın Redif Müşirliği adıyla yönetimi Aydın muhassılı Yakup Paşa'ya verilmiştir. ${ }^{14}$ Böylece 1836 yılına kadar sancak merkezi olan şehir, bu tarihten Aydın Müşirliği'nin merkezi haline gelmiştir.

Karaosmanoğlu ailesinden 1806 senesinde vefat eden Polad Mehmet Ağa'nın oğlu Hac1 Eyüp Ağa'nın kardeşi olan Yakup Ağa, 1821 senesinde Mora ordusu nüzûl eminliğine tayin edilmiş olup 1826 senesinde ise kapıcıbaşılık unvanına nail olmuştur. 1828 yılına gelindiğinde ise Siroz ayanlığı da yapan Yakup Ağa 1830 senesinde vezirliğe yükseltilerek devlet erkânı zümresine girmiş ve paşa unvanını almıştır. Bu tarihten sonra 1831 yılında Preveze muhafızlığ görevinde bulunan Paşa'ya 1833 senesinde ise bu göreve ilaveten Aydın muhasılllı̆ı da verilmiştir. ${ }^{15}$ Yakup Paşa 1833 yılından itibaren Aydın Güzelhisarı'nın yönetimine 1833-1840, 1843-1845 ve 1847-1848 yılları arasında olmak üzere üç defa atanmıştır. ${ }^{16}$ Yakup Paşa müşirliği döneminde askeri ve mali sorunların da dışında bir belediye başkanı gibi Aydın halkının su ihtiyacının karşılanmasına yönelik olarak suyollarını tamir ettirip çeşmeler yaptırmıştır. Yakup Paşa, Kuyucak’a Kayran Deresi'nden su kemerleri ve suyolları ile su getirtmiştir. Bu getirttiği suyu çeşmelere dağıtarak Kuyucak halkının su ihtiyacının giderilmesini sağlamıştır. Yakup Paşa iyi bir devlet adamı olmasının yanı sıra İstanbul, Aydın ve Kuyucak’ta birçok eser yaptırmıştır. İstanbul'da Dülger-zade Camii, Aydın çarsısında kendi adıyla anılan Yakup Paşa Hanı ile Ramazan Paşa Mahallesi’nde yaptırdığı Yahudihanesini sayabiliriz. ${ }^{17}$

\footnotetext{
${ }^{11}$ Çağatay Uluçay, Atçalı Kel Memed, As Matbaası, İstanbul 1968; Mehmet Başaran, Aysun Sarıbey Haykıran, Ali Özçelik, Atçalı Kel Mehmed Efe, Batı Anadolu'da Eşkıyalık ve Zeybeklik, Kitap Yayınevi, İstanbul 2018.

12 İsmail Hakkı Uzunçarşı11, "Mısır Valisi Mehmet Ali Paşa Kuvvetleri Tarafından Saruhan, Aydın ve İzmir'in İşgaline Dair Belgeler”, Belleten, c. XLVII, S. 185, Ankara 1984, s. 6-7; Fatih Gencer, “İbrahim Paşa'nın Anadolu'yu İstilası, (1832-1833)”, Uluslararası Sosyal Araştırmalar Dergisi, c. 9, S. 42, Şubat 2016, s. 652.

13 Aysun Sarıbey, a.g.t, s. 84.

${ }^{14}$ Musa Çadırcı, "Anadolu'da Redif Askeri Teşkilâtının Kuruluşu”, Tarih Araştırmaları Dergisi, S. VIII- XII / 14-23 Sene 1970-1974 (1975), s. 71.

${ }^{15}$ Yuzo Nagata, Tarihte Ayânlar Karaosmanoğlu Üzerinde Bir İnceleme, Türk Tarih Kurumu, Ankara 1997, s. 55-56.

${ }^{16}$ Sinan Kuneralp, Son Dönem Erkân ve Ricali (1839-1922) Prosopografik Rehber, İSİS, İstanbul 1999, s. $26,125$.

${ }^{17}$ Mustafa Kenan Özkan, “Aydın Valisi Yakup Paşanın Kuyucak'da Yaptırdığı Eserler”, Cumhuriyetin 75. Yılı Milet Müzesi Yıllı̆̆, S. 1, Söke 1997, s. 22.
} 
Görüldüğü üzere defterimizde de önemli yer tutan Yakup Paşa'nın müşirliği sırasında 1843 yılından 1850 yılına kadar Güzelhisar merkez konumu sürmüş, Damad Halil Paşa'nın Aydın

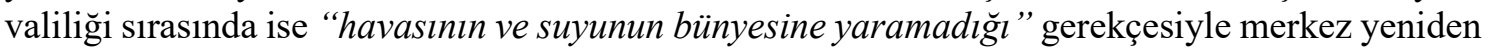
İzmir'e taşınmıştır. ${ }^{18}$

\section{Nüfus Sayımında Yakup Paşa ve Maiyeti}

Defterde “Aydın Eyaleti saye-i bahş atufetlü iclal olan devletlü fehametlï Yakup Paşa Hazretleri” başlığ ile ilk sayfada yer alan bilgiler bize Karaosmanoğlu Yakup Paşa ve maiyeti hakkında bilgi vermektedir. ${ }^{19}$

Yukarıda da belirttiğimiz üzere Aydın yönetim tarihinde önemli bir yer tutan Yakup Paşa'nın maiyetinde çeşitli dallarda 72 kişi bulunmaktaydı.

\begin{tabular}{|c|c|}
\hline Yakup Paşa'nın Maiyetinin Görevleri & Görevli Kişi Sayısı \\
\hline Asakir-i Nizamiye-i Şahanede maiyet-i müşiride Emir Çavuşu & 2 \\
\hline Divan-1 Hümayundan ve ketebe-i müşiriden & 2 \\
\hline Kavas & 16 \\
\hline Aşçı & 3 \\
\hline Duhanc1 & 2 \\
\hline Kahveci & 2 \\
\hline Ketebeden & 2 \\
\hline Mühürdar & 2 \\
\hline Peskir Ağas & 2 \\
\hline Çamaşır Ağas1 & 1 \\
\hline Divan Kâtibi hacegan divan-1 Hümayundan & 1 \\
\hline Dividdar & 1 \\
\hline Duhancı Baş1 & 1 \\
\hline Hazine Kâtibi & 1 \\
\hline İbrikdar & 1 \\
\hline Kahveci Yamağ 1 & 1 \\
\hline Kahvecibass & 1 \\
\hline Kalemde ketebe & 1 \\
\hline Kilerci & 1 \\
\hline Mirahor & 1 \\
\hline Ser kavasan hazret-i müsiri & 1 \\
\hline Seyis Bass & 1 \\
\hline Seyis Sakas & 1 \\
\hline Sofrac1 & 1 \\
\hline Sofracibaşı & 1 \\
\hline Şamdan Ağas 1 & 1 \\
\hline Seker Ağas & 1 \\
\hline Tatar ağas1 & 1 \\
\hline Vekilharc & 1 \\
\hline Tomruk Müdürü & 1 \\
\hline
\end{tabular}

${ }^{19}$ Devlet Arşivleri Başkanlığı Osmanlı Arşivi (BOA), Nüfus Defterleri (NFS.d.), Defter Kodu: 3013, s. 2-3. 
Yakup Paşa'nın yanında bulunan görevlilerin isimleri;

\begin{tabular}{|c|c|c|c|}
\hline Görevlilerin İsimleri & $\begin{array}{c}\text { İsimlere } \\
\text { Sahip } \\
\text { Olanların } \\
\text { Sayısı }\end{array}$ & $\begin{array}{c}\text { Görevlilerin } \\
\text { Babalarının İsimleri }\end{array}$ & $\begin{array}{c}\text { Babaların } \\
\text { sahip } \\
\text { oldukları } \\
\text { isimlerin } \\
\text { sayısı }\end{array}$ \\
\hline Hüseyin & 10 & Abdullah & 14 \\
\hline Mehmed & 9 & Mehmed & 10 \\
\hline Mustafa & 7 & İbrahim & 8 \\
\hline Osman & 7 & Mustafa & 7 \\
\hline Ahmed & 4 & Ahmed & 4 \\
\hline Hasan & 4 & Hasan & 4 \\
\hline İbrahim & 4 & Hüseyin & 4 \\
\hline Ali & 3 & Osman & 4 \\
\hline İsmail & 3 & Ali & 3 \\
\hline Ömer & 3 & Ömer & 3 \\
\hline Bekir & 2 & Yusuf & 3 \\
\hline Halil & 2 & Memiş & 2 \\
\hline 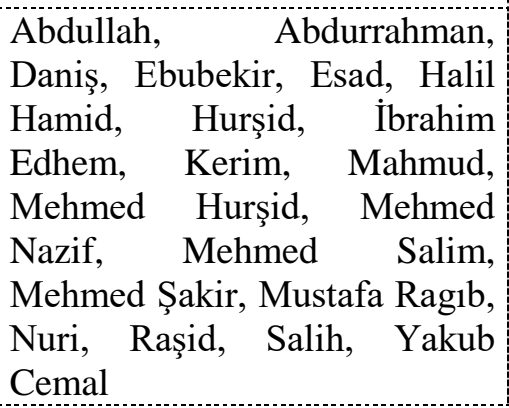 & 1'er & $\begin{array}{l}\text { Abdi, Behram, Ísmail, } \\
\text { Mahmud, Salih, Veli, } \\
\text { Yahya, Yakub }\end{array}$ & 1'er \\
\hline
\end{tabular}

Yukarıda verdiğimiz isimlerden kırk bir kişi Ağa, 7 kişi Efendi ve bir kişi Bey ve bir kişi de Arap ön eklerini kullanmaktaydılar.

Görevlilerin birbirleriyle ilişki derecelerine baktığımız zaman 15 görevlinin arkadaş, sekiz görevlinin tebaa, iki görevlinin yeğen, bir görevlinin oğul ve bir görevlinin de kayınbiraderlik ilişkisi içinde olduğu anlaşılmaktadır.

Yakup Paşa'nın maiyetinde yer alan bu kişilerin nereden geldiklerini nüfus defterinde yer alan bilgilerden öğrenmekteyiz.

Bunlar;

\begin{tabular}{|l|c|}
\hline \multicolumn{1}{|c|}{ Görevlilerin Geldikleri Yerler } & Sayllar \\
\hline Manisalı & 7 \\
\hline Manastırl1 & 6 \\
\hline Edirneli & 5 \\
\hline Tireli & 4 \\
\hline Bolulu & 3 \\
\hline Cerkez & 3 \\
\hline Eğinli & \\
\hline
\end{tabular}




\begin{tabular}{|l|c|}
\hline Eğribozlu & 3 \\
\hline Selanikli & 3 \\
\hline Asitaneli & 2 \\
\hline Kayserili & 2 \\
\hline Kemahlı & 2 \\
\hline Lofçalı & 2 \\
\hline Moral1 & 1 er \\
\hline Siroz (Serez) & \\
\hline Amasyal1, Darendeli, Erzurumlu, Filibeli, & \\
Foçal1, Gürcü, Harputlu, İslimiyeli, İşodralı, \\
Karpuzlulu, Kizılhisarl, Malatyalı, Misırl, \\
Nevşehirli, Nişli, Ödemişli, Pirlibeyli, Silivrili, \\
Vidinli, Yanyalı
\end{tabular}

Fiziksel özellikleri açısından ise görevliler orta boylu özelliği göstermektedirler. 39 kişi orta boylu, 20 kişi uzun boylu, 15 kişi uzunca boylu ve bir kişi ise kısa boyludur.

Görevliler gösterdiği bir başka fiziksel özellik ise bıyık ve sakal konumuyla ilgili olup, bıyıklı bir yapı sergilemektedirler.

İki kişi ise şabb-1 emred olarak kayıtlarda yer almaktadır.

Bu özellikler;

\begin{tabular}{|c|c|c|c|}
\hline Bıyık Özellikler & Biyıklı Sayısı & Sakal Özellikleri & Sakallı Sayısı \\
\hline Kumral Biyıklı & 25 & Kara Sakallı & 1 \\
\hline Kara Biylklı & 15 & Kir Sakallı & 1 \\
\hline Ter Kara Biyıkl1 & 7 & & \\
\hline Sar1 Biyıkl1 & 6 & & \\
\hline Ter Biylkl1 & 4 & & \\
\hline Kara Az B1y1kl1 & 3 & & \\
\hline Sar1 Kumral Biyıli & 3 & & \\
\hline Kumral Az B1yıkl1 & 2 & & \\
\hline Sarı Ter Biyıklı & 2 & & \\
\hline K1rca B1y1kl1 & 1 & & \\
\hline Kirca Kara Biyıkl & 1 & & \\
\hline Ter Kumral Biy1kl1 & 1 & & \\
\hline Ter Sarı Bıyıklı & 1 & & \\
\hline
\end{tabular}

Nüfus defterinden öğrendiğimiz önemli bir içerik yaşlardır. Defterde "sinn” diye geçen bu bilgiye göre Karaosmanoğlu Yakup Paşa'nın maiyetinde bulunanlar beş ile 55 yaş aralığında bulunmakta ve bu da 28 yaş ortalamasını vermektedir. 


\begin{tabular}{|c|c|c|c|c|c|c|c|}
\hline \multirow{21}{*}{ 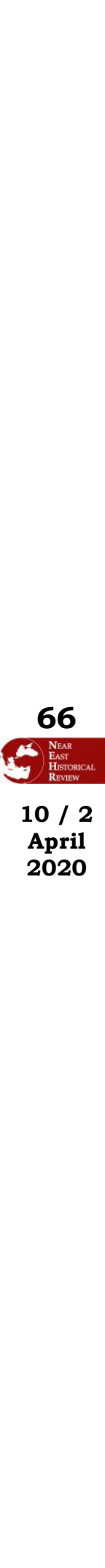 } & No & $\begin{array}{c}\text { Yakınlık } \\
\text { Derecesi ve } \\
\text { Maiyetinin } \\
\text { Niteliği }\end{array}$ & $\begin{array}{c}\text { Fiziksel } \\
\text { Özellikleri }\end{array}$ & $\begin{array}{l}\text { Maiyetinin } \\
\text { Mesleği }\end{array}$ & $\begin{array}{l}\text { Maiyetinin } \\
\text { Geldiği Yer }\end{array}$ & İsim & Yaş \\
\hline & 1 & & $\begin{array}{l}\text { Orta Boylu Kara } \\
\text { Sakallı }\end{array}$ & $\begin{array}{l}\text { Müşarünileyh } \\
\text { Hazretlerinin Divan } \\
\text { Kâtibi Hocagan } \\
\text { Divan-1 } \\
\text { Hümayundan }\end{array}$ & Edirneli & Esad Efendi & 35 \\
\hline & 2 & Tebaası & $\begin{array}{l}\text { Uzunca Boylu } \\
\text { Kara Biyıklı }\end{array}$ & & Edirneli & $\begin{array}{l}\text { Îsmail bin } \\
\text { Hüseyin }\end{array}$ & 23 \\
\hline & 3 & Tebaas & $\begin{array}{l}\text { Uzunca Boylu } \\
\text { Kara Byykl1 }\end{array}$ & & İslimiyeli & $\begin{array}{l}\text { Omer bin } \\
\text { Mehmed }\end{array}$ & 24 \\
\hline & 4 & & $\begin{array}{l}\text { Uzun Boylu Kara } \\
\text { Az Biyıkl }\end{array}$ & Ketebeden & Silivrili & $\begin{array}{l}\text { Osman Efendi } \\
\text { bin Hüseyin } \\
\text { Efendi }\end{array}$ & 24 \\
\hline & 5 & & $\begin{array}{l}\text { Uzun Boylu Sar } \\
\text { Ter Biyıkl }\end{array}$ & $\begin{array}{l}\text { Divan-1 } \\
\text { Hümayundan } \\
\text { ve Ketebe-i } \\
\text { Müsiriden }\end{array}$ & Edirneli & $\begin{array}{l}\text { Daniş Efendi } \\
\text { bin Ahmed } \\
\text { Efendi }\end{array}$ & 25 \\
\hline & 6 & Tebaası & $\begin{array}{l}\text { Orta Boylu } \\
\text { Kumral Az Biyıklı }\end{array}$ & & Nişli & $\begin{array}{l}\text { Mustafa bin } \\
\text { Yahya }\end{array}$ & 23 \\
\hline & 7 & & $\begin{array}{l}\text { Uzun Boylu Ter } \\
\text { Biyıkl1 }\end{array}$ & Hazine Kâtibi & Manisal1 & $\begin{array}{l}\text { İbrahim Efendi } \\
\text { bin el-Hacc } \\
\text { Mehmed Ağa }\end{array}$ & 26 \\
\hline & 8 & Oğlu & & & & Halil Hamid & 5 \\
\hline & 9 & Kaynı & Uzun Boylu & Ketebeden & Eğribozlu & $\begin{array}{l}\text { Osman Efendi } \\
\text { bin Ahmed }\end{array}$ & 25 \\
\hline & 10 & Yeğeni & $\begin{array}{l}\text { Uzunca Boylu Sar1 } \\
\text { Byyıkl1 }\end{array}$ & & & $\begin{array}{l}\text { Yakub Cemal } \\
\text { Bey bin } \\
\text { Mustafa }\end{array}$ & 26 \\
\hline & 11 & Tebaas & $\begin{array}{l}\text { Uzunca Boylu Ter } \\
\text { Kara Biykll. }\end{array}$ & & Tireli & $\begin{array}{l}\text { Hüseyin bin } \\
\text { Mustafa }\end{array}$ & 20 \\
\hline & 12 & Tebaası & & & & $\begin{array}{l}\text { Ahmed bin } \\
\text { Mustafa }\end{array}$ & 12 \\
\hline & 13 & Arkadaş1 & $\begin{array}{l}\text { Orta Boylu Kara } \\
\text { Biyıklı }\end{array}$ & Mühürdar & Çerkez & $\begin{array}{l}\text { Mehmed Salim } \\
\text { Efendi bin } \\
\text { Abdullah }\end{array}$ & 23 \\
\hline & 14 & Arkadaş1 & $\begin{array}{l}\text { Kisa Boylu } \\
\text { Kumral Biyıklı }\end{array}$ & Mühürdar & Çerkez & $\begin{array}{l}\text { Mustafa Ragib } \\
\text { bin Abdullah }\end{array}$ & 23 \\
\hline & 15 & & $\begin{array}{l}\text { Orta Boylu Kara } \\
\text { Biyıklı }\end{array}$ & Dividdar & Gürcü & $\begin{array}{l}\text { Rasid Efendi } \\
\text { bin Abdullah }\end{array}$ & 25 \\
\hline & 16 & Tebaas1 & $\begin{array}{l}\text { Orta Boylu Ter } \\
\text { Biyıkl1 }\end{array}$ & & Eğribozlu & $\begin{array}{l}\text { Mahmud bin } \\
\text { Mehmed }\end{array}$ & 16 \\
\hline & 17 & & $\begin{array}{l}\text { Uzun Boylu Kara } \\
\text { Biyıkl1 }\end{array}$ & Sofracıbaş1 & İşkodralı & $\begin{array}{l}\text { Mustafa Ağa } \\
\text { bin Mehmed }\end{array}$ & 27 \\
\hline & 18 & Arkadaș & $\begin{array}{l}\text { Orta Boylu } \\
\text { Kumral Biylkl }\end{array}$ & Sofrac1 & Cerkez & $\begin{array}{l}\text { Mustafa Aga } \\
\text { bin Abdullah }\end{array}$ & 27 \\
\hline & 19 & & $\begin{array}{l}\text { Uzun Boylu } \\
\text { Kumral Biyıklı }\end{array}$ & Vekilharç & & $\begin{array}{l}\text { Mehmed Şakir } \\
\text { Ağa bin } \\
\text { Mehmed }\end{array}$ & 27 \\
\hline & 20 & & $\begin{array}{l}\text { Uzun Boylu Kara } \\
\text { Biylkl1 }\end{array}$ & Peșkir Ağası & Edirneli & $\begin{array}{l}\text { Ismail Ağa bin } \\
\text { Hasan }\end{array}$ & 35 \\
\hline
\end{tabular}




\begin{tabular}{|c|c|c|c|c|c|c|}
\hline No & \begin{tabular}{|c} 
Yakınlık \\
Derecesi ve \\
Maiyetinin \\
Niteliği
\end{tabular} & $\begin{array}{l}\text { Fiziksel } \\
\text { Özellikleri }\end{array}$ & $\begin{array}{l}\text { Maiyetinin } \\
\text { Mesleği }\end{array}$ & $\begin{array}{l}\text { Maiyetinin } \\
\text { Geldiği Yer }\end{array}$ & İsim & Yaş \\
\hline 21 & Arkadaş1 & $\begin{array}{l}\text { Orta Boylu Kara } \\
\text { Az Bıyıklı }\end{array}$ & Peşkir Ağası & Asitaneli & $\begin{array}{l}\text { Halil Ağa bin } \\
\text { Mahmud }\end{array}$ & 22 \\
\hline 22 & & $\begin{array}{l}\text { Orta Boylu } \\
\text { Kumral Biyıkl1 }\end{array}$ & Şamdan Ağası & Lofçalı & $\begin{array}{l}\text { Hüseyin Ağa } \\
\text { bin Osman }\end{array}$ & 28 \\
\hline 23 & Arkadaș1 & $\begin{array}{l}\text { Orta Boylu } \\
\text { Kumral Biykl }\end{array}$ & Șeker Ağası & Selanikli & $\begin{array}{l}\text { Nuri Ağa bin } \\
\text { Abdullah }\end{array}$ & 30 \\
\hline 24 & & $\begin{array}{l}\text { Orta Boylu Kara } \\
\text { Biyıklı }\end{array}$ & Duhanc1 Baș1 & Manisal1 & $\begin{array}{l}\text { Kerim Ağa bin } \\
\text { Hacı Mehmed }\end{array}$ & 25 \\
\hline 25 & Yeğeni & $\begin{array}{l}\text { Orta Boylu Şabb-1 } \\
\text { Emred }\end{array}$ & Kalemde ketebe & Manisalı & $\begin{array}{l}\text { Mehmed bin } \\
\text { Hacı İbrahim }\end{array}$ & 18 \\
\hline 26 & Arkadaş1 & $\begin{array}{l}\text { Orta Boylu Ter } \\
\text { Kara Biyıklı }\end{array}$ & Duhanc1 & Manisalı & $\begin{array}{l}\text { Hüseyin Ağa } \\
\text { bin Osman }\end{array}$ & 22 \\
\hline 27 & Arkadaş1 & $\begin{array}{l}\text { Uzunca Boylu Ter } \\
\text { Kara Biyıkl }\end{array}$ & Duhanc1 & Eğinli & $\begin{array}{l}\text { Halil Ağa bin } \\
\text { Ali }\end{array}$ & 22 \\
\hline 28 & Arkadaş1 & $\begin{array}{l}\text { Orta Boylu Kara } \\
\text { Biyıkl1 }\end{array}$ & İbrikdar & Manastırl & $\begin{array}{l}\text { Hurşid Ağa bin } \\
\text { Abdullah }\end{array}$ & 25 \\
\hline 29 & & $\begin{array}{l}\text { Orta Boylu Sar1 } \\
\text { Biyıkl }\end{array}$ & Kahvecibaș & & $\begin{array}{l}\text { Mehmed Nazif } \\
\text { Ağa bin } \\
\text { Abdullah }\end{array}$ & 30 \\
\hline 30 & Tebaası & $\begin{array}{l}\text { Orta Boylu Ter } \\
\text { Kara Biyıkl }\end{array}$ & & Malatyalı & Ali bin Mustafa & 22 \\
\hline 31 & & $\begin{array}{l}\text { Uzunca Boylu } \\
\text { Kumral Biyıklı }\end{array}$ & Kahveci Yamağı & Erzurumlu & $\begin{array}{l}\text { Ahmed Ağa bin } \\
\text { Yakub }\end{array}$ & 37 \\
\hline 32 & Arkadaş1 & $\begin{array}{l}\text { Uzun Boylu Kara } \\
\text { Biyıkl1 }\end{array}$ & Kahveci & Selanikli & $\begin{array}{l}\text { Hüseyin Ağa } \\
\text { bin Salih }\end{array}$ & 28 \\
\hline 33 & Arkadaş1 & $\begin{array}{l}\text { Uzun Boylu Ter } \\
\text { Kara Biylklı }\end{array}$ & Kahveci & Manisalı & $\begin{array}{l}\text { Mehmed Ağa } \\
\text { bin Abdullah }\end{array}$ & 22 \\
\hline 34 & & $\begin{array}{l}\text { Uzun Boylu Ter } \\
\text { Sar1 Biyıklı }\end{array}$ & Çamaşır Ağası & Foçalı & $\begin{array}{l}\text { Ali Ağa bin } \\
\text { Abdullah }\end{array}$ & 20 \\
\hline 35 & & $\begin{array}{l}\text { Uzunca Boylu } \\
\text { kumral Biyıklı }\end{array}$ & Mirahor & Pirlibeyli & $\begin{array}{l}\text { Hüseyin Ağa } \\
\text { bin Behram }\end{array}$ & 30 \\
\hline 36 & & $\begin{array}{l}\text { Uzun Boylu } \\
\text { Kumral Biyıklı }\end{array}$ & & Yanyali & $\begin{array}{l}\text { Osman Ağa bin } \\
\text { Hasan }\end{array}$ & 30 \\
\hline 37 & Tebaası & $\begin{array}{l}\text { Uzun Boylu } \\
\text { Kumral az Biyıklı }\end{array}$ & & Manastırlı & $\begin{array}{l}\text { Mehmed bin } \\
\text { Ömer }\end{array}$ & 23 \\
\hline 38 & & $\begin{array}{l}\text { Uzun Boylu } \\
\text { Kumral Biyıklı }\end{array}$ & & Darendeli & $\begin{array}{l}\text { Salih Ağa bin } \\
\text { İbrahim }\end{array}$ & 27 \\
\hline 39 & & $\begin{array}{l}\text { Uzun Boylu Ter } \\
\text { Kumral Biyıkl }\end{array}$ & & & $\begin{array}{l}\text { Ibrahim Edhem } \\
\text { Ağa bin } \\
\text { Abdullah }\end{array}$ & 20 \\
\hline 40 & & $\begin{array}{l}\text { Uzun Boylu } \\
\text { Kumral Biyklı }\end{array}$ & & Moral1 & $\begin{array}{l}\text { Mehmed Ağa } \\
\text { bin Veli }\end{array}$ & 34 \\
\hline 41 & & $\begin{array}{l}\text { Uzunca Boylu } \\
\text { Kara Biyılkl }\end{array}$ & & Filibeli & $\begin{array}{l}\text { Mehmed Hurşid } \\
\text { Ağa bin } \\
\text { Abdullah }\end{array}$ & 22 \\
\hline 42 & Arkadaş1 & $\begin{array}{l}\text { Uzunca Boylu Sar1 } \\
\text { Biyıklı }\end{array}$ & Kilerci & Kizılhisarlı & $\begin{array}{l}\text { Ismail Ağa bin } \\
\text { Mustafa }\end{array}$ & 33 \\
\hline 43 & & $\begin{array}{l}\text { Orta Boylu Ter } \\
\text { Biylkl }\end{array}$ & & Tireli & $\begin{array}{l}\text { Hasan Ağa bin } \\
\text { Mehmed }\end{array}$ & 21 \\
\hline
\end{tabular}




\begin{tabular}{|c|c|c|c|c|c|c|}
\hline No & $\begin{array}{l}\text { Yakınlık } \\
\text { Derecesi ve } \\
\text { Maiyetinin } \\
\text { Niteliği }\end{array}$ & $\begin{array}{c}\text { Fiziksel } \\
\text { Özellikleri }\end{array}$ & $\begin{array}{l}\text { Maiyetinin } \\
\text { Mesleği }\end{array}$ & $\begin{array}{l}\text { Maiyetinin } \\
\text { Geldiği Yer }\end{array}$ & İsim & Yaş \\
\hline 44 & & $\begin{array}{l}\text { Uzun Boylu Ter } \\
\text { Kara Biykl }\end{array}$ & & Ödemişli & $\begin{array}{l}\text { Mehmed Ağa } \\
\text { bin Abdullah }\end{array}$ & 22 \\
\hline 45 & & $\begin{array}{l}\text { Uzun Boylu } \\
\text { Kumral Biyıklı }\end{array}$ & $\begin{array}{l}\text { Asakir-i Nizamiye-i } \\
\text { Şahanede Maiyet-i } \\
\text { Müşiride Emir } \\
\text { Çavuşu }\end{array}$ & Selanikli & $\begin{array}{l}\text { Mehmed Ağa } \\
\text { bin Hüseyin }\end{array}$ & 29 \\
\hline 46 & & $\begin{array}{l}\text { Uzunca Boylu } \\
\text { Kumral Bıyıklı }\end{array}$ & $\begin{array}{l}\text { Asakir-i Nizamiye-i } \\
\text { Şahanede Maiyet-i } \\
\text { Müşiride Emir } \\
\text { Çavuşu }\end{array}$ & Edirneli & $\begin{array}{l}\text { Ahmed bin } \\
\text { Mustafa }\end{array}$ & 27 \\
\hline 47 & & $\begin{array}{l}\text { Orta Boylu } \\
\text { Kumral Biylkl1 }\end{array}$ & Tatar ağas1 & Asitaneli & $\begin{array}{l}\text { Hasan Ağa bin } \\
\text { Hasan }\end{array}$ & 55 \\
\hline 48 & Arkadaş1 & $\begin{array}{l}\text { Orta Boylu } \\
\text { Kumral Biy1kl1 }\end{array}$ & & $\begin{array}{l}\text { Siroz } \\
\text { (Serez) }\end{array}$ & Osman Ağa bin & 30 \\
\hline 49 & & $\begin{array}{l}\text { Orta Boylu Kara } \\
\text { Biykl1 }\end{array}$ & Assçı Baş1 & Bolulu & $\begin{array}{l}\text { Mehmed Ağa } \\
\text { bin Hasan }\end{array}$ & 45 \\
\hline 50 & Arkadaş1 & $\begin{array}{l}\text { Orta Boylu } \\
\text { Kumral Biyıkl }\end{array}$ & Assce & Bolulu & $\begin{array}{l}\text { Osman bin } \\
\text { İbrahim }\end{array}$ & 30 \\
\hline 51 & Arkadaş1 & $\begin{array}{l}\text { Orta Boylu } \\
\text { Kumral Biy1kl1 }\end{array}$ & Assci & & $\begin{array}{l}\text { Ahmed bin } \\
\text { Ibrahim }\end{array}$ & 30 \\
\hline 52 & Arkadaş1 & $\begin{array}{l}\text { Orta Boylu Ter } \\
\text { Kara Biyıkli }\end{array}$ & Assç & Bolulu & $\begin{array}{l}\text { Mustafa bin } \\
\text { Ahmed }\end{array}$ & 20 \\
\hline 53 & & $\begin{array}{l}\text { Orta Boylu Kara } \\
\text { Biylkl1 }\end{array}$ & Seyis Sakas1 & Harputlu & $\begin{array}{l}\text { İbrahim bin } \\
\text { Mustafa }\end{array}$ & 45 \\
\hline 54 & & $\begin{array}{l}\text { Uzun Boylu Kara } \\
\text { Biyskl1 }\end{array}$ & Seyis Baş & Misirli & $\begin{array}{l}\text { Abdullah Arap } \\
\text { bin Ali }\end{array}$ & 29 \\
\hline 55 & & $\begin{array}{l}\text { Orta Boylu Sarı } \\
\text { Kumral Biyıklı }\end{array}$ & $\begin{array}{l}\text { Ser Kavasan } \\
\text { Hazret-i Müsiri }\end{array}$ & $\begin{array}{l}\text { Siroz } \\
\text { (Serez) }\end{array}$ & $\begin{array}{l}\text { Hüseyin Ağa } \\
\text { bin Abdullah }\end{array}$ & 35 \\
\hline 56 & & $\begin{array}{l}\text { Uzun Boylu } \\
\text { Kumral Biyıkl1 }\end{array}$ & & Edirneli & $\begin{array}{l}\text { Mehmed Ağa } \\
\text { bin Hüseyin }\end{array}$ & 33 \\
\hline 57 & & $\begin{array}{l}\text { Orta Boylu } \\
\text { Kumral Biy1kl1 }\end{array}$ & Kavas & Amasyalı & $\begin{array}{l}\text { Ömer Ağa bin } \\
\text { Ömer }\end{array}$ & 27 \\
\hline 58 & & $\begin{array}{l}\text { Orta Boylu Kara } \\
\text { Biylkl1 }\end{array}$ & Kavas & Kemahlı & $\begin{array}{l}\text { Hüseyin Ağa } \\
\text { bin İbrahim }\end{array}$ & 25 \\
\hline 59 & & $\begin{array}{l}\text { Orta Boylu Sarı } \\
\text { Kumral Biyıkl }\end{array}$ & Kavas & Lofçalı & $\begin{array}{l}\text { Hasan bin } \\
\text { Osman }\end{array}$ & 25 \\
\hline 60 & & $\begin{array}{l}\text { Orta Boylu } \\
\text { Kumral Biy1kl1 }\end{array}$ & Kavas & Manastırl1 & $\begin{array}{l}\text { Mustafa bin } \\
\text { Abdi }\end{array}$ & 27 \\
\hline 61 & & $\begin{array}{l}\text { Uzunca Boylu Sar1 } \\
\text { Kumral Biyıkl1 }\end{array}$ & Kavas & Manastırl1 & $\begin{array}{l}\text { Abdurrahman } \\
\text { Ağa bin İsmail }\end{array}$ & 35 \\
\hline 62 & & $\begin{array}{l}\text { Uzunca Boylu } \\
\text { Kumral Biy1kl1 }\end{array}$ & Kavas & Nevşehirli & $\begin{array}{l}\text { Ebubekir Ağa } \\
\text { bin Memis }\end{array}$ & 45 \\
\hline 63 & & $\begin{array}{l}\text { Orta Boylu } \\
\text { Kumral Biy1kl1 }\end{array}$ & Kavas & Eğinli & $\begin{array}{l}\text { Osman Ağa bin } \\
\text { Ahmed }\end{array}$ & 38 \\
\hline 64 & & $\begin{array}{l}\text { Orta Boylu Sarı } \\
\text { Biyıkl }\end{array}$ & Kavas & Eğinli & $\begin{array}{l}\text { Ibrahim Ağa bin } \\
\text { Ömer }\end{array}$ & 38 \\
\hline 65 & & $\begin{array}{l}\text { Uzun Boylu } \\
\text { Kumral Biyıkl1 }\end{array}$ & Kavas & & $\begin{array}{l}\text { Hüseyin Ağa } \\
\text { bin Yusuf }\end{array}$ & 29 \\
\hline 66 & & $\begin{array}{l}\text { Orta Boylu } \\
\text { Kumral Biyıkl }\end{array}$ & Kavas & Eğribozlu & $\begin{array}{l}\text { Mustafa Ağa } \\
\text { bin Yusuf }\end{array}$ & 34 \\
\hline
\end{tabular}




\begin{tabular}{|c|c|c|c|c|c|c|}
\hline No & \begin{tabular}{|c|} 
Yakınlık \\
Derecesi ve \\
Maiyetinin \\
Niteliği
\end{tabular} & $\begin{array}{c}\text { Fiziksel } \\
\text { Özellikleri }\end{array}$ & $\begin{array}{l}\text { Maiyetinin } \\
\text { Mesleği }\end{array}$ & $\begin{array}{l}\text { Maiyetinin } \\
\text { Geldiği Yer }\end{array}$ & İsim & Yaş \\
\hline 67 & & $\begin{array}{l}\text { Uzunca Boylu } \\
\text { Kara Biyıl1 }\end{array}$ & Kavas & Vidinli & $\begin{array}{l}\text { Bekir Ağa bin } \\
\text { Mehmed }\end{array}$ & 33 \\
\hline 68 & & $\begin{array}{l}\text { Orta Boylu Kara } \\
\text { Az Bıyıklı }\end{array}$ & Kavas & Karpuzlulu & $\begin{array}{l}\text { Mustafa bin } \\
\text { Mehmed }\end{array}$ & 24 \\
\hline 69 & & $\begin{array}{l}\text { Orta Boylu Kirca } \\
\text { Kara Biyıklı }\end{array}$ & Kavas & Manastırlı & $\begin{array}{l}\text { Osman bin } \\
\text { Yusuf }\end{array}$ & 32 \\
\hline 70 & & $\begin{array}{l}\text { Orta Boylu } \\
\text { Kumral Biyıklı }\end{array}$ & Kavas & Kayserili & $\begin{array}{l}\text { Omer bin } \\
\text { Osman }\end{array}$ & 35 \\
\hline 71 & & $\begin{array}{l}\text { Uzunca Boylu } \\
\text { Kirca Biyılk1 }\end{array}$ & Kavas & Kayserili & $\begin{array}{l}\text { Bekir bin } \\
\text { Memiş }\end{array}$ & 38 \\
\hline 72 & & $\begin{array}{l}\text { Orta Boylu } \\
\text { Kumral Biyıkl }\end{array}$ & Kavas & Kemahl1 & $\begin{array}{l}\text { Hüseyin bin } \\
\text { İbrahim }\end{array}$ & 22 \\
\hline 1 & & $\begin{array}{l}\text { Uzunca Boylu Kir } \\
\text { Sakallı }\end{array}$ & Tomruk Müdürü & Manisalı & $\begin{array}{l}\text { Mehmed Ağa } \\
\text { bin Ali }\end{array}$ & 50 \\
\hline 2 & Tebaası & $\begin{array}{l}\text { Orta Boylu Sarı } \\
\text { Biyıklı }\end{array}$ & & Moralı & $\begin{array}{l}\text { Hasan bin } \\
\text { İbrahim }\end{array}$ & 30 \\
\hline 3 & Tebaası & $\begin{array}{l}\text { Orta Boylu Ter } \\
\text { Biyıkl1 }\end{array}$ & & Manisalı & Ali bin Mehmed & 19 \\
\hline 4 & Tebaası & $\begin{array}{l}\text { Orta Boylu Sar } \\
\text { B1yıkl1 }\end{array}$ & & Tireli & $\begin{array}{l}\text { İbrahim bin } \\
\text { İbrahim }\end{array}$ & 28 \\
\hline 5 & Tebaası & $\begin{array}{l}\text { Orta Boylu Şabb-1 } \\
\text { Emred }\end{array}$ & & Tireli & $\begin{array}{l}\text { Hüseyin bin } \\
\text { Abdullah }\end{array}$ & 16 \\
\hline
\end{tabular}

\section{Nüfus Sayımında Aydın Defterdarı ve Maiyeti}

Defterde geçen başka bir konu Aydın Defterdarı ve maiyeti ile ilgili bilgilerdir. ${ }^{20}$

"Ecille-i Rical-i Devlet-i Aliyye Aydın defterdarı" başlı̆̆ını ile verilen bu bilgilerden "Raşid Bey Efendi Hazretleri"nin Aydın defterdarı olduğu anlaşılmaktadır. 1845 yılında "Asitane” yani İstanbul'dan geldiği, Orta Boylu, Kırca Seyrek Kumral Sakallı fiziksel özelliklere sahip olduğu ve yaşının 45 olduğu belirtilmekteydi.

Defterdarın aynı zamanda 14 kişiden oluşan "tebaası" bulunmaktaydı. Bunların üçü Asitane yani İstanbul, ikisi Üsküdar'dan, Amasya, Beyşehir, Edremid, İznikmid, Keban Maden ve Üsküp'den de birer kişi Aydın'a gelmekteydiler. 20 ile 55 yaş aralığında olup, ortalama yaşları ise 31,5 'dur.

Bu kişilerin genel listesi şöyledir:

\begin{tabular}{|c|c|c|c|c|c|}
\hline No & $\begin{array}{l}\text { Maiyetinin } \\
\text { Mesleği }\end{array}$ & Fiziksel Özellikleri & $\begin{array}{l}\text { Maiyetinin } \\
\text { Geldiği Yer }\end{array}$ & İsim & Yaş \\
\hline 1 & Tebaası & Orta Boylu Kır & $\begin{array}{l}\text { Asitaneli } \\
\text { Vürudu } 1262\end{array}$ & $\begin{array}{l}\text { Hac1 Mehmed Emin } \\
\text { Efendi bin Ömer } \\
\text { Efendi }\end{array}$ & 55 \\
\hline 2 & Tebaasi & Uzunca Boylu Kara Biyıklı & Aydınli & $\begin{array}{l}\text { Ahmed Ağa bin } \\
\text { Hüseyin }\end{array}$ & 35 \\
\hline
\end{tabular}

${ }^{20}$ BOA, NFS.d. 3013, s. 5. 


\begin{tabular}{|c|c|c|c|c|c|}
\hline No & $\begin{array}{l}\text { Maiyetinin } \\
\text { Mesleği }\end{array}$ & Fiziksel Özellikleri & $\begin{array}{l}\text { Maiyetinin } \\
\text { Geldiŏi Yer }\end{array}$ & İsim & Yaş \\
\hline 3 & Tebaası & Orta Boylu Ter Kara Bıyıkl & Asitaneli & $\begin{array}{l}\text { Hurşid Ağa bin } \\
\text { Abdullah }\end{array}$ & 25 \\
\hline 4 & Tebaas1 & Uzunca Boylu Kara Biyıklı & Ussküdarlı & Said Ağa bin Halil & 34 \\
\hline 5 & Tebaas1 & Uzun Boylu Sar1 Biyıl1 & Usküdarlı & $\begin{array}{l}\text { Islam Ağa bin } \\
\text { Mehmed }\end{array}$ & 32 \\
\hline 6 & Tebaas1 & Orta Boylu Kara Biyıklı & Asitaneli & Sabri Ağa bin Sadik & 35 \\
\hline 7 & Tebaas1 & Uzun Boylu Kumral Biyıklı & Úsküblü & $\begin{array}{l}\text { Abdullah Ağa bin } \\
\text { Osman }\end{array}$ & 35 \\
\hline 8 & Tebaas1 & $\begin{array}{l}\text { Uzunca Boylu Kumral } \\
\text { Biy1kl1 }\end{array}$ & & $\begin{array}{l}\text { Hüseyin Ağa bin } \\
\text { Selim }\end{array}$ & 31 \\
\hline 9 & Tebaas1 & Uzun Boylu Kumral Biyıklı & Beyşehirli & $\begin{array}{l}\text { Osman Ağa bin } \\
\text { Ömer Efendi }\end{array}$ & 26 \\
\hline 10 & Tebaas1 & Orta Boylu Sabb-1 Emred & Amasyalı & $\begin{array}{l}\text { Mehmed Ağa bin } \\
\text { Haci Mehmed }\end{array}$ & 20 \\
\hline 11 & Tebaas 1 & Orta Boylu Ter Kara Biyıklı & Keban Madenli & $\begin{array}{l}\text { Ahmed Ağa bin } \\
\text { Hasan }\end{array}$ & 25 \\
\hline 12 & Tebaas1 & Orta Boylu Sar1 Bıyıklı & & $\begin{array}{l}\text { Ali Osman Ağa bin } \\
\text { İbrahim }\end{array}$ & 35 \\
\hline 13 & Tebaas1 & Uzunca Boylu Kara Bıyıklı & İnnikmidli & $\begin{array}{l}\text { Ahmed Ağa bin } \\
\text { Ömer }\end{array}$ & 28 \\
\hline 14 & Tebaas1 & $\begin{array}{l}\text { Orta Boylu Kumral Az } \\
\text { Biyıkl1 }\end{array}$ & Edremidli & $\begin{array}{l}\text { Hacı Mustafa Ağa } \\
\text { bin İbrahim }\end{array}$ & 25 \\
\hline
\end{tabular}

Defter içinde yer alan bir başka bilgi ise Defterdarın maiyetinde bulunan "ketebe-i müstahdem" listesidir.

İlk sırada "Aydın Eyaleti Emval Başkâtibi" yer almaktadır. "Asitaneli" yani İstanbullu olup, 27 yaşında "Mustafa Faik Efendi bin Mehmed Emin” adını taşımaktadır. Fiziksel özellik olarak da Orta Boylu ve Sarı Sakallı'dır.

Maiyeti ise şu kişilerden oluşmaktadır:

\begin{tabular}{|c|c|c|c|c|c|}
\hline No & $\begin{array}{l}\text { Maiyetinin } \\
\text { Mesleği }\end{array}$ & Fiziksel Özellikleri & $\begin{array}{c}\text { Maiyetinin } \\
\text { Geldiği } \\
\text { Yer }\end{array}$ & İsim & Yaş \\
\hline 2 & Uşağ1 & Uzunca Boylu Ter Biyıkl1 & Çerkes & Hasan bin Osman & 22 \\
\hline 3 & $\begin{array}{l}\text { Emval } \\
\text { Kâtibi } \\
\text { Refiki }\end{array}$ & $\begin{array}{l}\text { Uzunca Boylu Kumral } \\
\text { Sakall1 }\end{array}$ & Asitaneli & $\begin{array}{l}\text { es-Seyyid Halil Hilmi } \\
\text { Efendi bin Mehmed } \\
\text { Hasib Efendi }\end{array}$ & 26 \\
\hline 4 & $\begin{array}{l}\text { Gulam1 } \\
\text { Zenci }\end{array}$ & & & Yaver bin Abdullah & 12 \\
\hline 5 & Uşağ1 & Orta Boylu Ter Kara Biyıkl & Bursal1 & Mehmed bin Abdullah & 25 \\
\hline 6 & Refiki & $\begin{array}{l}\text { Uzunca Boylu Kumral } \\
\text { Sakall }\end{array}$ & Asitaneli & $\begin{array}{l}\text { es-Seyyid Ahmed Raşid } \\
\text { Efendi bin el-Hacc es- } \\
\text { Seyyid Mehmed Ağa }\end{array}$ & 37 \\
\hline 7 & Refiki & $\begin{array}{l}\text { Orta Boylu Az Kumral } \\
\text { Sakall }\end{array}$ & Asitaneli & $\begin{array}{l}\text { Mustafa Şevki Efendi } \\
\text { bin Mustafa }\end{array}$ & 22 \\
\hline
\end{tabular}




\begin{tabular}{|c|c|c|c|c|c|}
\hline 8 & Gulamı & & & Selim bin Abdullah & 10 \\
\hline 9 & Refiki & Orta Boylu Kumral Biyıkli & Tokatli & Hasan Efendi bin Hasan & 28 \\
\hline 10 & Refiki & Kısa Boylu Müzellef Sakallı & Gördesli & $\begin{array}{l}\text { Nuh Necati Efendi bin } \\
\text { Mehmed }\end{array}$ & 25 \\
\hline 11 & Refiki & Orta Boylu Kumral Sakallı & Asitaneli & $\begin{array}{l}\text { Mehmed Şems Efendi } \\
\text { bin Mustafa Efendi }\end{array}$ & 33 \\
\hline 12 & Pederi & Orta Boylu Kır Sakallı & & $\begin{array}{l}\text { Mustafa Efendi bin } \\
\text { Hüseyin }\end{array}$ & 70 \\
\hline 13 & Biraderi & & & $\begin{array}{lll}\text { Hasan } & \text { Tahsin } & \text { bin } \\
\text { Mustafa } & & \end{array}$ & 11 \\
\hline 14 & Mahdumu & & & $\begin{array}{l}\text { Mehmed Galip bin } \\
\text { Mehmed Şems }\end{array}$ & 2 \\
\hline
\end{tabular}

Defter içinde yer alan bir başka bilgi ise Aydın Hâkimi ve maiyeti ile ilgili listedir. ${ }^{21}$

50 yaşında olan bu kişi “Çarşambalızade el-Hacc Said Efendi bin Mehmed Efendi" olup, Asitanelidir. Kısa Boylu ve Kır Sakallı olarak da fiziksel özellikleri verilmiştir.

Maiyeti ise şu kişilerden oluşmaktadır:

\begin{tabular}{|c|c|c|c|c|c|}
\hline No & Maiyetinin Mesleği & Fiziksel Özellikleri & $\begin{array}{c}\text { Maiyetinin } \\
\text { Geldiği } \\
\text { Yer }\end{array}$ & İsim & Yaş \\
\hline 2 & Kethüdası & Uzunca Boylu Kara Sakallı & Asitaneli & $\begin{array}{l}\text { Osman Efendi bin } \\
\text { Mustafa }\end{array}$ & 35 \\
\hline 3 & Hademesi & Orta Boylu Kara Biyıkl1 & Arapkirli & $\begin{array}{l}\text { Mustafa Ağa bin } \\
\text { İsmail }\end{array}$ & 33 \\
\hline 4 & Tebaas1 & Orta Boylu Kara Biy1kl1 & Malatyalı & Bekir bin Mehmed & 30 \\
\hline 5 & Tebaas1 & Orta Boylu Sarı Biyıklı & Rumelili & $\begin{array}{l}\text { Hacı Köylü } \\
\text { Mehmed bin } \\
\text { Mestan }\end{array}$ & 36 \\
\hline 6 & Tebaas1 & Orta Boylu Sarı Biylkl & Asitaneli & Ali bin İbrahim & 27 \\
\hline 7 & Tebaas1 & Orta Boylu Sabb-1 Emred & & $\begin{array}{l}\text { Zenci Bilal bin } \\
\text { Abdullah }\end{array}$ & 20 \\
\hline
\end{tabular}

Defter içinde yer alan bir başka bilgi ise Aydın'da bulunan "zabtiye hıdmetinde bulunan süvariyanın..." ve “piyadegan" isimlerini ve özelliklerini içeren listedir. ${ }^{22}$

Bu listede 52 süvari ve piyade zaptiyesi kayıtlı bulunmaktadır. 45 ve 25 yaş aralığında olup, 29 yaş ortalaması sahiptir. Fiziksel özellik açısından da daha çok bıyıklı olan zaptiyeler orta boy seviyesindedirler.

${ }^{21}$ BOA, NFS.d. 3013, s. 6.

22 BOA, NFS.d. 3013, s. 3-5. 
Genel fiziksel özellikleri şöyledir:

\begin{tabular}{|c|c|c|c|c|c|}
\hline Bıyık Ozellikleri & Biyıklı Sayısı & Sakal Ozellikleri & Sakallı Sayısı & $\begin{array}{c}\text { Boy } \\
\text { Özellikleri }\end{array}$ & $\begin{array}{c}\text { Boy } \\
\text { Sayıs! }\end{array}$ \\
\hline Kumral Biyıklı & 39 & Kirca Sakallı & 3 & Orta Boylu & 31 \\
\hline Kumral Az Biy1kl1 & 3 & Kumral Sakallı & 2 & $\begin{array}{l}\text { Uzunca } \\
\text { Boylu }\end{array}$ & 21 \\
\hline Kara Biyıkli & 2 & & & & \\
\hline Kırca Biyıkl1 & 2 & & & & \\
\hline Ter Biyıklı & 2 & & & & \\
\hline
\end{tabular}

Süvariyan Listesi ve Özellikleri

72

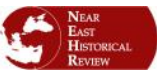

$10 / 2$

April 2020

\begin{tabular}{|c|c|c|c|c|}
\hline No & Fiziksel Özellikleri & Geldiği Yer & İsim & Yaș \\
\hline 1 & Orta Boylu Kumral Biyıklı & Moralı & Hasan bin İbrahim & 33 \\
\hline 2 & Uzunca Boylu Kumral Biyıkl1 & Antalyali & Perissan Ali bin Hasan & 35 \\
\hline 3 & Uzunca Boylu Kara Biy1kl1 & Tosyal1 & Ali bin Hüseyin & 30 \\
\hline 4 & Uzunca Boylu Kumral Sakalli & Balıkesirli & Ali bin Halil & 40 \\
\hline 5 & Uzunca Boylu Kumral Biyıkl1 & Karpuzlulu & Ali bin Yusuf & 24 \\
\hline 6 & Orta Boylu Kumral Sakalli & Kemahli & Mehmed bin Abdullah & 25 \\
\hline 7 & Orta Boylu Kumral Biy1kl1 & Manisal1 & İbrahim bin Mehmed & 24 \\
\hline 8 & Uzunca Boylu Kumral Az Biyıkli & Tosyal1 & Ahmed bin Hasan & 22 \\
\hline 9 & Orta Boylu Kumral Biyılk1 & Manisalı & Küçük Hasan bin Hacı Said & 25 \\
\hline 10 & Orta Boylu Kumral Biy1kl1 & Kayserili & Hüseyin bin Mehmed & 25 \\
\hline 11 & Uzunca Boylu Kumral Biyıkl1 & Tiranl1 & Bayram bin Hasan & 32 \\
\hline 12 & Orta Boylu Kumral Biysklı & Kuyucakli & Mustafa bin Mehmed & 28 \\
\hline 13 & Uzunca Boylu Kırca Sakallı & Manisalı & Bassıozuk Hüseyin bin Hasan & 45 \\
\hline 14 & Orta Boylu Kumral Biysklı & Denizlili & Ali bin Mustafa & 25 \\
\hline 15 & Orta Boylu Kumral Biylkl1 & Eğinli & Mahmud bin Abdullah & 35 \\
\hline 16 & Orta Boylu Kumral Az Biylkl & Manisal1 & Küçük Ali bin Mehmed & 25 \\
\hline 17 & Uzunca Boylu Kumral Biyıkl1 & Tosyal1 & Ali bin Bekir & 28 \\
\hline 19 & Orta Boylu Kumral Biyıkl1 & Ahiskali & Mehmed Serif bin Abdullah & 30 \\
\hline 18 & Orta Boylu Kumral Biy1kl1 & Alaiyeli & Bekir bin Ahmed & 24 \\
\hline 20 & Uzunca Boylu Kumral Biy1kl1 & Konyali & Mustafa bin Ali & 23 \\
\hline 21 & Orta Boylu Kara Biyıkl1 & Manastırl & Salih bin İbrahim & 40 \\
\hline 22 & Orta Boylu Kumral Bıyıklı & Giridli & Osman bin Mehmed & 30 \\
\hline 23 & Orta Boylu Kumral Biyskl1 & Kütahyalı & Tosun Mustafa bin Mehmed & 30 \\
\hline 24 & Uzunca Boylu Kumral Biy1kli & Alaşehirli & Ahmed bin Abdullah & 26 \\
\hline 25 & Uzunca Boylu Kumral Biy1kl & Manastırlı & Talib bin Süleyman & 35 \\
\hline 26 & Uzunca Boylu Kumral Biy1kl1 & Eğribozlu & Salih Raşid bin Abdullah & 35 \\
\hline 27 & Uzunca Boylu Kumral Biy1kl & Eğribozlu & İbrahim bin Veyis & 25 \\
\hline 28 & Orta Boylu Kumral Biyıklı & Moralı & Hasan bin Osman & 28 \\
\hline 29 & Orta Boylu Kumral Biyıklı & Kemahli & İbrahim bin Osman & 40 \\
\hline 30 & Uzunca Boylu Kumral Biy1kl1 & Manisal1 & Hüseyin bin Abdullah & 25 \\
\hline 31 & Orta Boylu Kumral Biyıklı & & Hacı Salih bin Hacı Nasuh & 25 \\
\hline
\end{tabular}




\section{Piyadegan Listesi ve Özellikleri}

\begin{tabular}{|c|c|c|c|c|}
\hline No & Fiziksel Özellikleri & Geldiği Yer & İsim & Yaş \\
\hline 1 & Orta Boylu Kırca Sakallı & Kemahli & Mustafa bin Hac1 İdris & 44 \\
\hline 2 & Orta Boylu Kirca Biyıkl1 & Atçal1 & Kasım bin Kasım & 45 \\
\hline 3 & Uzunca Boylu Kumral Biyıkl1 & Donduranl1 & İbrahim bin Mustafa & 25 \\
\hline 4 & Orta Boylu Kumral Biyıkl1 & Yenipazarl1 & Hüseyin bin Mustafa & 25 \\
\hline 5 & Uzunca Boylu Kumral Biyıkl1 & Atçal1 & Hasan bin Mustafa & 25 \\
\hline 6 & Orta Boylu Kumral Biyıklı & Koçakl1 & Ömer bin Hacı Abdurrahman & 26 \\
\hline 7 & Orta Boylu Kumral Biyıkl1 & Yenipazarl1 & Ahmed bin Mehmed & 25 \\
\hline 8 & Uzunca Boylu Kirca Sakalli & Manisal1 & Mehmed bin Mehmed & 45 \\
\hline 9 & Orta Boylu Kumral Bıyıkl & Üsküblü & Ali bin Hasan & 25 \\
\hline 10 & Orta Boylu Kumral Biyıkl1 & Manisali & Hüseyin bin Mehmed & 25 \\
\hline 11 & Uzunca Boylu Kumral Az Biyıkl & Yenipazarl1 & Ahmed bin Mustafa & 22 \\
\hline 12 & Uzunca Boylu Kumral Biyıkl1 & Sobiceli & Hasan bin Hacı Hasan & 35 \\
\hline 13 & Orta Boylu Ter Biy1kl1 & Sobiceli & Mustafa bin Hasan & 20 \\
\hline 14 & Uzunca Boylu Kumral Biyıkl1 & Manastirli & Mustafa bin Ali & 25 \\
\hline 15 & Uzunca Boylu Kumral Byykl1 & Balyal1 & Ali bin Ali & 30 \\
\hline 16 & Orta Boylu Kumral Biyıklı & Yenipazarl1 & Küçük Ali bin Mehmed & 30 \\
\hline 17 & Orta Boylu Kumral Biyıkl1 & Manisali & Mehmed Ali bin Süleyman & 25 \\
\hline 18 & Orta Boylu Kumral Biyıklı & Atçalı & İsmail oğlu Ali bin İsmail & 25 \\
\hline 19 & Orta Boylu Kumral Biyıl1 & Sarayköylü & Ali bin Abdullah & 25 \\
\hline 20 & Orta Boylu Ter Biyıkl1 & Donduranl1 & İbrahim bin Mustafa & 20 \\
\hline 21 & Orta Boylu Kumral Byyklı & Atçal1 & Hasan Ali bin Benli Hac1 Ahmed & 25 \\
\hline
\end{tabular}

\section{Medreseler}

İslâm dünyasında, eğitim-öğretim faaliyetleri. Hz. Muhammed (s.a.v.) döneminden beri, büyük ölçüde mescit veya ulema evlerinde yapılmaktaydı, ancak zaman içinde eğitim-öğretim işleri gereksinimler bağlamında yeni kurumların ortaya çıkmasına olanaklı kıldı. Bu gereksinim, yaklaşık X. ve XI. yüzyıllarda medreselerin doğmasına yol açtı. Bu konudaki en önemli gelişme Büyük Selçuklu Veziri Nizamü'l-Mülk'ün adıyla anılan medresedir. Kurucusuna izafeten Nizamiye Medreseleri adı verilen bu medreselerde öğrenimin parasız yapıldığı, muhtaç öğrencilere burs sağlandığı, okuyan öğrencilerin, barınma ihtiyaçlarının karşılandığ görülmektedir. ${ }^{23}$

$\mathrm{Bu}$ aşamalarla birlikte dönemin bilim adamlarının Aydınoğlu Mehmet Bey’in sarayında büyük itibar gördükleri de bilinmektedir. XIV. yüzyılın ilk yarısı içinde Aydınoğlu Beyliği'nin sarayını ziyaret eden ünlü Seyyah İbn Battûta, burada Mehmet Bey’in ilim adamlarına gösterdiği itibarı bizzat görmüştür. ${ }^{24}$

\footnotetext{
${ }^{23}$ Mefahil, Hızlı, "Kuruluşundan Osmanlılara Kadar Medreseler”, Uludă̆ Üniversitesi ilahiyat Fakültesi Dergisi, c. 2, S. 2, Bursa 1987, s. 275

${ }^{24}$ İbn Battûta Seyahatnamesi, c. I, Çev. A. Sait Aykut, Yapı Kredi Yayınları, İstanbul 2000, s. 420-421. Ayrıca bkz. Mehmet Şeker, İbn-i Batuta'ya Göre Anadolu'nun Sosyal- Kültürel ve İktisadî Hayatı ile Ahîlik, II. Baskı, Kültür Bakanlığı Yayınları, Ankara 2000, s. 44.
} 
Aydınoğlu Mehmet Bey zamanında başlayan kültür faaliyetleri Umur ve İsa Beyler zamanında da sürmüştür. Başta Aydınoğulları Beyliği'nin kurucusu Mehmet Bey olmak üzere diğer beylerin de ilim adamlarını himaye ettikleri gerek kendi himayelerine alarak gerekse dolaylı olarak onları destekledikleri açıç̧a görüldüğü gibi kurmuş oldukları medreselerle de ilmi faaliyetleri canlandırdıkları bilinmektedir. ${ }^{25}$ Aydıneli coğrafyasının Osmanlı hâkimiyetine geçtikten sonrada aynı ilmi canlılığın devam ettiği görülmektedir. Aydın ve çevresinde Aydınoğulları Beyliği döneminde sayıları hızla artan medreselerin varlığına modern eğitim kurumlarının sayısının arttığı XIX. yüzyılda da rastlanılması kültürel mirasının kuşaktan kuşağa aktarıldığının en büyük ispatıdır. ${ }^{26}$

\section{ve Sayısı}

Nüfus Defterinde İsmi Geçen Medreseler ve Buralarda Barınan Kişilerin Özellikleri

1845 tarihli nüfus sayımında Aydın Güzelhisar Kazası merkezinde ve kazaya bağlı bazı köylerde Cihanzade, Osmanzade nam-1 diğer Nasuh Paşa, Kocaavlu, İbrahim Ağa, Çiçekli, Veysi Paşa, Kubbeli Mescid, Cami-i Kebir, Dayızade, Alihan, Eski Yeni, Abacızade, Ramazan Paşa, Yukarı ve Aşağı Zeynzade, Bey, Zincirli nam-1 diğer Kozdibi, Çelik Paşa, Ağaçarası nam-1 diğer Ahmet Paşa, Çarıkçızade, Hacı Suhtezade, Cincinlizade, Çilingirzade, Ali Hoca, İhtisab, Yağıroğlu, Akmescid, Posacıoğlu, Dükkanönü, Zincirli nam-1 diğer Yarbaşı isimli olmak üzere 29 medresenin kaydı bulunmaktadır. Toplamda 250 kişinin yer aldığı, aşağıda listesini ayrıntılı olarak verdiğimiz bu medreselerde sekiz ve 85 yaş aralığında kişiler yer almaktadır. Bunların da 25 yaş ortalamasında olduğu anlaşılmaktadır.

Fiziksel özellik olarak da "orta boylu” ve "sakallı" kişilerle birlikte "şabb-ı emred" veya "ter bıyıklı" kişiler de önemli yer tutmaktadırlar.

İsimlerinin önünde "Molla" ekinin yaygın olarak kullanıldığı medrese öğrencilerinin çoğunluğu sırasıyla "Mehmed", "Mustafa", "Ali" ve "Ahmed" isimlerini kullanmaktaydılar.

$\mathrm{Bu}$ kişiler değişik yerlerden aşağıda isimlerini saydığımız ve ayrıntılı olarak verdiğimiz birçok yerleşim yerinden gelmekteydiler. Bu yerleşim yerleri de ağırlıklı olarak Çine, Karahayıt, Birgi, Mandalyat ve Sultanhisar'1 gibi yerler olmaktayd.

\section{Cihanzade Medresesi ${ }^{27}$}

Dedeköy Çarşısı'nda bulunan Cihanzade Medresesi'ni Cihanzade Abdülaziz Efendi yaptırmıştır. ${ }^{28}$

Defterde 12 kişinin kaydı bulunmaktadır. 14 ile 40 yaş aralığına sahip bu kişilerin ortalama yaş seviyesi 25'dir. Fiziksel özellik olarak da "Orta Boylu" ve "Sakallı" özellik göstermektedirler. Mehmed ve Mustafa ağırlıklı isimler "Molla" diye anılmaktadırlar.

\footnotetext{
${ }^{25}$ Mehmet Şeker, “Aydınoğullarının Kültür Hayatı ve Türkçeciliği”, Uluslararası Batı Anadolu Tarih Kültür ve Medeniyeti Sempozyumu I Aydınoğulları Tarihi Bildiriler, Ed. Prof. Dr. Mehmet Ersan, Prof. Dr. Mehmet Şeker, Prof. Dr. Cüneyt Kanat, Türk Tarih Kurumu, Ankara 2013, s. 370.

${ }^{26}$ Maarif salnamelerine göre, 1884'te Aydın Sancağı'nda 49 medrese bulunmaktadır. Ayrıntılı bilgi için bkz: Çiğdem Taş, Maârif Salnamelerine Göre 20. Yüzyıl Başlarında (1898-1904) Aydın Vilâyeti'nde Eğitim, Basılmamış Yüksek Lisans Tezi, Afyon Kocatepe Üniversitesi, Sosyal Bilimler Enstitüsü, Afyon 2006, s. 12.

${ }^{27}$ BOA, NFS.d. 3013, s. 6.

${ }^{28}$ Abdulhalim Durma, Evliyalar Şehri Aydın, s. 40.
} 


\begin{tabular}{|c|c|c|c|c|c|}
\hline $\begin{array}{l}\mathbf{N} \\
\mathbf{o}\end{array}$ & $\begin{array}{c}\text { Medresede Bulunan } \\
\text { Kişinin Geldiği Yer }\end{array}$ & \begin{tabular}{|c|} 
Yakınlık \\
Derecesi ve \\
Maiyetinin \\
Niteliği \\
\end{tabular} & $\begin{array}{c}\text { Fiziksel } \\
\text { Özellikleri }\end{array}$ & İsim & Yaş \\
\hline 1 & & & $\begin{array}{l}\text { Kısa Boylu Köse } \\
\text { Kumral Sakallı }\end{array}$ & $\begin{array}{l}\text { Ali Baba oğlu Hac1 } \\
\text { Molla Ahmed bin Ali }\end{array}$ & 40 \\
\hline 2 & \begin{tabular}{|l} 
Sivrihisar Kazas 1 \\
canibinden \\
gelmiştir Sene 58
\end{tabular} & & $\begin{array}{l}\text { Orta Boylu Kara } \\
\text { Sakallı }\end{array}$ & $\begin{array}{l}\text { Veli oğlu Abdullah } \\
\text { Efendi bin Mustafa }\end{array}$ & 40 \\
\hline 3 & $\begin{array}{l}\text { Koçak Kazası } \\
\text { Kuralarından } \\
\text { Akçe Karyesi (Tokat } \\
\text { Erbaa) Sene } 45\end{array}$ & & $\begin{array}{l}\text { Orta Boylu Kara } \\
\text { Sakallı }\end{array}$ & $\begin{array}{l}\text { Hatib oğlu Molla } \\
\text { Mustafa bin İbrahim }\end{array}$ & 33 \\
\hline 4 & $\begin{array}{l}\text { Atça Kazasından } \\
\text { gelmiştir Sene } 55\end{array}$ & & $\begin{array}{l}\text { Orta Boylu Kumral } \\
\text { Sakallı }\end{array}$ & $\begin{array}{l}\text { Cansız oğlu Molla } \\
\text { Mustafa bin Mustafa }\end{array}$ & 30 \\
\hline 5 & $\begin{array}{l}\text { Kara Tekeli } \\
\text { Aşiretinden... gelmiştir } \\
\text { Sene } 58\end{array}$ & & $\begin{array}{l}\text { Orta Boylu Kara } \\
\text { Sakallı }\end{array}$ & $\begin{array}{l}\text { Imam oğlu Molla } \\
\text { Mustafa Efendi bin } \\
\text { Mehmed }\end{array}$ & 25 \\
\hline 6 & $\begin{array}{l}\text { Kara Tekeli } \\
\text { Assiretinden gelmiştir } \\
\text { Sene } 58\end{array}$ & Çömezi & $\begin{array}{l}\text { Orta Boylu Taze } \\
\text { Sakallı }\end{array}$ & $\begin{array}{l}\text { Uzun Mustafa oğlu } \\
\text { Molla Ali bin Mustafa }\end{array}$ & 22 \\
\hline 7 & $\begin{array}{l}\text { Bolacal1 Aşiretinden } \\
\text { gelmiştir Sene } 58\end{array}$ & Çömezi & $\begin{array}{l}\text { Orta Boylu } \\
\text { Müzellef Sakallı }\end{array}$ & $\begin{array}{l}\text { Beşe oğlu Molla } \\
\text { İbrahim bin Mehmed }\end{array}$ & 21 \\
\hline 8 & $\begin{array}{l}\text { Bolacalı Aşiretinden } \\
\text { gelmiştir Sene } 58\end{array}$ & Çömezi & $\begin{array}{l}\text { Orta Boylu Şabb-1 } \\
\text { Emred }\end{array}$ & $\begin{array}{l}\text { Talha oglu Molla Talha } \\
\text { bin Mehmed }\end{array}$ & 20 \\
\hline 9 & $\begin{array}{l}\text { Kara Tekeli } \\
\text { Aşiretinden gelmiştir } \\
\text { Sene } 58\end{array}$ & Çömezi & $\begin{array}{l}\text { Orta Boylu Şabb-1 } \\
\text { Emred }\end{array}$ & $\begin{array}{l}\text { Halil oğlu Molla } \\
\text { Mehmed bin Ali }\end{array}$ & 19 \\
\hline 10 & $\begin{array}{l}\text { Antalya canibinden } \\
\text { gelmiştir Sene } 52\end{array}$ & & $\begin{array}{l}\text { Orta Boylu Köse } \\
\text { Kumral Sakallı }\end{array}$ & $\begin{array}{l}\text { Mahmud oğlu Hac1 } \\
\text { Ahmed Efendi bin } \\
\text { Mahmud }\end{array}$ & 19 \\
\hline 11 & $\begin{array}{l}\text { Birgi Kazasından } \\
\text { gelmiştir Sene } 60\end{array}$ & & $\begin{array}{l}\text { Uzun Boylu } \\
\text { Müzellef Sakallı }\end{array}$ & $\begin{array}{l}\text { Bıyı oğlu Hac1 } \\
\text { Mehmed Efendi bin } \\
\text { Hacı Halil }\end{array}$ & 15 \\
\hline 12 & $\begin{array}{l}\text { Sobice Kazasına tabi } \\
\text { Akpınar Karyesinden } \\
\text { gelmiştir Sene } 57\end{array}$ & & $\begin{array}{l}\text { Uzun Boylu Ter } \\
\text { Biyıkli }\end{array}$ & $\begin{array}{l}\text { Kurlı Bekir oğlu Molla } \\
\text { Bekir bin Veli }\end{array}$ & 14 \\
\hline
\end{tabular}

\section{Osmanzade nam-ı diğer Nasuh Paşa ${ }^{29}$}

Köprülü Mahallesi'nde bulunan külliye Nasuh Paşa tarafından H. 1120 / M. 1708 tarihlidir. Medrese ve medreseye ait bir mescit, han (Zincirli Han), hamamdan (Nasuh Paşa Hamamı) meydana gelen külliye büyük bir alana yayılmıştır. ${ }^{30}$ Köprülü Mahallesi'nde Osmanoğlu Nasuh Paşa tarafından yaptırılan medrese 1898 yılında Sarayköylü Mustafa Efendi’nin müderrisliğinde işlerliğini sürdürmekteydi. ${ }^{31}$

\footnotetext{
${ }^{29}$ BOA, NFS.d. 3013 , s. 7.

${ }^{30}$ Türkiye'de Vakıf Abideler ve Eski Eserler, Vakıflar Genel Müdürlüğü Yayınları, 2. Baskı, Ankara 1983, s. 669-673.

${ }^{31}$ Çiğdem Taş a.g.t., s. 83.
} 
Defterde Nasuh Paşa Medresesi'nde dokuz kişinin kaydı bulunmaktadır. 13 ile 50 yaş aralı̆̆ına sahip bu kişilerin ortalama yaş seviyesi 31'dir. Fiziksel özellik olarak da "Orta Boylu" ve "Sakallı" özellik göstermektedirler. Mehmed ağırlıklı isim olup, "Molla" öneki de bütün isimlerde kullanılmaktadır.

\begin{tabular}{|c|c|c|c|c|}
\hline $\begin{array}{l}\mathbf{N} \\
\mathbf{o}\end{array}$ & $\begin{array}{l}\text { Medresede Bulunan Kişinin } \\
\text { Geldiği Yer ve Görevi }\end{array}$ & Fiziksel Özellikleri & İsim & Yaş \\
\hline 1 & $\begin{array}{l}\text { Nasuh Paşa Cami-i Şerifi } \\
\text { Kayyumu }\end{array}$ & Orta Boylu Ak Sakallı & $\begin{array}{l}\text { Pirli Sar1 Molla Ahmed } \\
\text { bin Ali }\end{array}$ & 50 \\
\hline 2 & $\begin{array}{l}\text { Şahme Kazasından gelmiştir } \\
\text { Sene } 50 \\
\text { Gökyaka Karyeli }\end{array}$ & Orta Boylu Ter Bıyıklı & Molla Halil bin Hacı Ali & 20 \\
\hline 3 & & Orta Boylu Ak Sakallı & $\begin{array}{l}\text { Pirli Molla Hüseyin bin } \\
\text { Hüseyin }\end{array}$ & 85 \\
\hline 4 & $\begin{array}{l}\text { Şahme Kazasından gelmiştir } \\
\text { Sene } 60 \text { Saraçlar Karyeli }\end{array}$ & $\begin{array}{l}\text { Orta Boylu Kara } \\
\text { Sakall }\end{array}$ & $\begin{array}{l}\text { Hasan Kethüda oğlu } \\
\text { İdris bin Hasan }\end{array}$ & 25 \\
\hline 5 & $\begin{array}{l}\text { Çine Kazasından gelmiştir } \\
\text { Sene } 48 \text { Kabataş Karyeli }\end{array}$ & $\begin{array}{l}\text { Uzunca Boylu Müzellef } \\
\text { Kumral Sakalli }\end{array}$ & Molla Kadiri bin İbrahim & 25 \\
\hline 6 & $\begin{array}{l}\text { Karapınar Nahiyesinden } \\
\text { gelmiştir Sene } 60 \text { Sandıklı } \\
\text { Karyeli }\end{array}$ & $\begin{array}{l}\text { Orta Boylu Şabb-1 } \\
\text { Emred }\end{array}$ & $\begin{array}{l}\text { Molla Mehmed bin } \\
\text { İsmail }\end{array}$ & 15 \\
\hline 7 & $\begin{array}{l}\text { Koçak Kazasından gelmiştir } \\
\text { Sene } 54 \text { Akçe Karyeli }\end{array}$ & $\begin{array}{l}\text { Orta Boylu Kara } \\
\text { Sakall }\end{array}$ & $\begin{array}{l}\text { Molla Mehmed bin Hac1 } \\
\text { Mehmed }\end{array}$ & 31 \\
\hline 8 & $\begin{array}{l}\text { Şahme Kazasından gelmiştir } \\
\text { Sene 59 Saraçlar Karyeli }\end{array}$ & $\begin{array}{l}\text { Orta Boylu Şabb-1 } \\
\text { Emred }\end{array}$ & $\begin{array}{l}\text { Molla Mehmed Salih bin } \\
\text { Emin Efendi }\end{array}$ & 15 \\
\hline 9 & $\begin{array}{l}\text { Şahme Kazasından gelmiştir } \\
\text { Sene } 59\end{array}$ & & Karındaşı Molla Osman & 13 \\
\hline
\end{tabular}

\section{Kocahavlu Medresesi ${ }^{32}$}

Defterde 15 kişinin kaydının bulunduğu Kocaavlu Medresesi'nin kuruluş yeri tespit edilememiştir. 12 ile 30 yaş aralığına sahip bu kişilerin ortalama yaş seviyesi 21'dir. Fiziksel özellik olarak da "Orta Boylu" ve "Uzun Boylu" ve "Sakallı" özellikleri göstermektedirler. Ayrıca bir kişinin de "sağ ayağı topal" olduğu belirtilmiştir.

Mehmed ağırlıklı isim olup, "Molla” öneki de bütün isimlerde kullanılmaktadır.

\begin{tabular}{|c|c|c|c|c|c|}
\hline $\begin{array}{l}\mathbf{N} \\
\mathbf{o}\end{array}$ & $\begin{array}{l}\text { Medresede Bulunan } \\
\text { Kișinin Geldiŏi Yer }\end{array}$ & $\begin{array}{c}\text { Yakınlık Derecesi } \\
\text { ve Maiyetinin } \\
\text { Niteliği }\end{array}$ & $\begin{array}{c}\text { Fiziksel } \\
\text { Özelikleri }\end{array}$ & İsim & Yas \\
\hline 1 & $\begin{array}{l}\text { Arpaz Kazasindan } \\
\text { gelmistir Sene } 42\end{array}$ & & $\begin{array}{l}\text { Uzun Boylu } \\
\text { Kara Sakalli }\end{array}$ & $\begin{array}{l}\text { Mehmed Efendi bin } \\
\text { Hasan }\end{array}$ & 30 \\
\hline 2 & $\begin{array}{l}\text { Arpaz Kazasından } \\
\text { gelmiştir Sene } 47 \\
\text { Köteli }\end{array}$ & & $\begin{array}{l}\text { Orta Boylu Kara } \\
\text { Sakallı }\end{array}$ & $\begin{array}{l}\text { Molla Mehmed bin } \\
\text { Hasan }\end{array}$ & 30 \\
\hline 3 & $\begin{array}{l}\text { Bozdoğan Kazasindan } \\
\text { gelmiştir Sene } 55 \\
\text { Bozdoğanl }\end{array}$ & & $\begin{array}{l}\text { Kısa Boylu } \\
\text { Müzellef Sakallı }\end{array}$ & $\begin{array}{l}\text { Hafiz İbrahim bin } \\
\text { Berber İbrahim }\end{array}$ & 21 \\
\hline
\end{tabular}

${ }^{32}$ BOA, NFS.d. 3013, s. 7. 


\begin{tabular}{|c|c|c|c|c|c|}
\hline 4 & $\begin{array}{l}\text { Arpaz Kazasina tabi } \\
\text { Dutağaç Karyesinden } \\
\text { gelmistir Sene } 58\end{array}$ & & $\begin{array}{l}\text { Orta Boylu Kara } \\
\text { Sakallı }\end{array}$ & $\begin{array}{l}\text { Çamıkçı oğlu Molla } \\
\text { Hüseyin bin Hasan }\end{array}$ & 22 \\
\hline 5 & $\begin{array}{l}\text { Arpaz Kazasina tabi } \\
\text { Dutağaç Karyesinden } \\
\text { gelmiştir Sene } 53\end{array}$ & Çömezi & $\begin{array}{l}\text { Kısa Boylu } \\
\text { Müzellef Sakallı } \\
\text { Sağ ayağı topal }\end{array}$ & $\begin{array}{l}\text { Arap Ali oğlu Molla } \\
\text { Hüseyin bin } \\
\text { Hüseyin }\end{array}$ & 20 \\
\hline 6 & $\begin{array}{l}\text { Arpaz Kazasına tabi } \\
\text { Dutağaç Karyesinden } \\
\text { gelmiştir Sene } 51\end{array}$ & & $\begin{array}{l}\text { Uzun Boylu } \\
\text { Müzellef Sakallı }\end{array}$ & $\begin{array}{l}\text { Kara Ahmed oğlu } \\
\text { Molla Hasan bin } \\
\text { Kara Ahmed }\end{array}$ & 23 \\
\hline 7 & $\begin{array}{l}\text { Arpaz Kazasına tabi } \\
\text { Dutağaç Karyesinden } \\
\text { gelmiştir Sene } 53\end{array}$ & Çömezi & $\begin{array}{l}\text { Uzun Boylu Ter } \\
\text { Bıyıklı }\end{array}$ & $\begin{array}{l}\text { Koca İbrahim oğlu } \\
\text { Molla Hasan bin } \\
\text { İbrahim }\end{array}$ & 17 \\
\hline 8 & $\begin{array}{l}\text { Arpaz Kazasina tabi } \\
\text { Dutağaç Karyesinden } \\
\text { gelmistir Sene } 49\end{array}$ & & $\begin{array}{l}\text { Orta Boylu } \\
\text { Köse Kumral } \\
\text { Sakall1 }\end{array}$ & $\begin{array}{l}\text { Yalniz oğlu Molla } \\
\text { Mehmed bin } \\
\text { Hüseyin }\end{array}$ & 25 \\
\hline 9 & $\begin{array}{l}\text { Birgi Kazasina tabi } \\
\text { Mendegüme } \\
\text { karyesinden gelmiştir } \\
\text { Sene } 49\end{array}$ & & $\begin{array}{l}\text { Orta Boylu } \\
\text { Kumral Sakall1 }\end{array}$ & $\begin{array}{l}\text { Molla Ali oğlu } \\
\text { Molla İbrahim bin } \\
\text { Molla Ali }\end{array}$ & 28 \\
\hline 10 & $\begin{array}{l}\text { Birgi Kazasina tabi } \\
\text { Mendegüme } \\
\text { Karyesinden gelmiştir } \\
\text { Sene } 53\end{array}$ & Çömezi & $\begin{array}{l}\text { Orta Boylu Ter } \\
\text { Biyıkl1 }\end{array}$ & $\begin{array}{l}\text { Dedeli oğlu Molla } \\
\text { Mehmed bin Salih }\end{array}$ & 16 \\
\hline 11 & $\begin{array}{l}\text { Birgi Kazasına tabi } \\
\text { Mendegüme } \\
\text { Karyesinden gelmiştir } \\
\text { Sene } 57\end{array}$ & Çömezi & & $\begin{array}{l}\text { İbrahim oğlu Molla } \\
\text { İbrahim bin } \\
\text { Süleyman }\end{array}$ & 12 \\
\hline 12 & $\begin{array}{l}\text { Birgi Kazasına tabi } \\
\text { Mendegüme } \\
\text { Karyesinden gelmiştir } \\
\text { Sene } 57\end{array}$ & Çömezi & $\begin{array}{l}\text { K1sa Boylu Ter } \\
\text { Biyıkl1 }\end{array}$ & $\begin{array}{l}\text { Salih Efendi oğlu } \\
\text { Molla Mehmed bin } \\
\text { Salih }\end{array}$ & 17 \\
\hline 13 & $\begin{array}{l}\text { Birgi Kazasına tabi } \\
\text { Mendegüme } \\
\text { Karyesinden gelmiştir } \\
\text { Sene } 51\end{array}$ & & $\begin{array}{l}\text { Orta Boylu } \\
\text { Müzellef } \\
\text { Kumral Sakall }\end{array}$ & $\begin{array}{l}\text { Kadı oğlu Molla } \\
\text { Hüseyin bin } \\
\text { Mehmed Efendi }\end{array}$ & 22 \\
\hline 14 & $\begin{array}{l}\text { Birgi Kazasina tabi } \\
\text { Mendegüme } \\
\text { Karyesinden gelmiştir } \\
\text { Sene } 50\end{array}$ & & $\begin{array}{l}\text { Uzun Boylu } \\
\text { Müzellef } \\
\text { Kumral Sakall1 }\end{array}$ & $\begin{array}{l}\text { Hatib oğlu Molla } \\
\text { Yahya bin Mehmed } \\
\text { Efendi }\end{array}$ & 20 \\
\hline 15 & $\begin{array}{l}\text { Birgi Kazasına tabi } \\
\text { Mendegüme } \\
\text { Karyesinden gelmiştir } \\
\text { Sene 50 }\end{array}$ & Karındaş1 & $\begin{array}{l}\text { Uzun Boylu } \\
\text { Köse Kumral } \\
\text { Sakallı }\end{array}$ & Molla Mehmed & 18 \\
\hline
\end{tabular}




\section{İbrahim Ağa Medresesi ${ }^{33}$}

Çıksorut Mahallesi'nde bulunan İbrahim Ağa Medresesi'nin banisi İbrahim Ağa'dır. Müderris Eyüp Efendi'nin 1898 yılında 17 talebesi varken bu sayı 1899-1903 yılları arasında 19'a ulaşır. ${ }^{34}$

Defterde dört kişinin kaydı bulunmaktadır. 15 ile 60 yaş aralığına sahip bu kişilerin ortalama yaş seviyesi 34,5'dur. Fiziksel özellik olarak da "Orta Boylu”, "Sakallı" ve "Şabb-ı Emred" özellikleri göstermektedirler.

Mustafa ağırlıklı isim olup, "Molla" ve "Derviş" öneki de bütün isimlerde kullanılmaktadır.

\begin{tabular}{|c|c|c|c|c|c|c|c|}
\hline & \multicolumn{2}{|c|}{$\begin{array}{l}\text { Medresede Bulunan Kişinin } \\
\text { Geldiği Yer }\end{array}$} & \multicolumn{3}{|c|}{ Fiziksel Özellikleri } & \multirow{2}{*}{$\begin{array}{l}\text { İsim } \\
\text { Pirli Derviş Mustafa bin } \\
\text { Mustafa }\end{array}$} & \multirow{2}{*}{$\begin{array}{l}\text { Yas } \\
60\end{array}$} \\
\hline 1 & & & $\begin{array}{l}\text { Uzun } \\
\text { Sakallı }\end{array}$ & Boylu & Kir & & \\
\hline 2 & & & $\begin{array}{l}\text { Orta } \\
\text { Sakall1 }\end{array}$ & Boylu & Köse & $\begin{array}{l}\text { Pirli Molla Mustafa bin } \\
\text { Mehmed }\end{array}$ & 45 \\
\hline 3 & & & $\begin{array}{l}\text { Orta } \\
\text { Emred }\end{array}$ & Boylu & Şabb-1 & $\begin{array}{l}\text { Pirli Molla Ahmed bin } \\
\text { Hac1 Ahmed }\end{array}$ & 18 \\
\hline & $\begin{array}{l}\text { Aydın'a tabi } \\
\text { Karyesinden gelmiştir } \\
\text { Sene } 61\end{array}$ & Serçe & $\begin{array}{l}\text { Orta } \\
\text { Emred }\end{array}$ & Boylu & Şabb-1 & $\begin{array}{l}\text { Molla Süleyman bin } \\
\text { Mehmed }\end{array}$ & 15 \\
\hline
\end{tabular}

\section{Çiçekli Medrese ${ }^{35}$}

Hisar Mahallesi'nde Mehmet Efendi tarafından yaptırılmış olan Çiçekli Medresesi'nin müderrisi Aydınlı Hafız Efendi'nin 1898 ve 1899 yıllarında 30 talebesi bulunmaktadır. Müderris Mehmet Efendi'nin 1900'deki müderrisliği surasında 32 talebesi yer alırken, 1901 ve 1903 yıllarında medresede yine 32 talebe eğitim görmektedir. ${ }^{36}$

Defterde iki kişinin kaydı bulunmaktadır. 22 ile 35 yaş aralığına sahip bu kişilerin ortalama yaş seviyesi 28,5'dur. Fiziksel özellik olarak da "Orta ve Kısa Boylu" ve "Sakallı" özellikleri göstermektedirler.

Ahmed ve Mehmed isimleri olup, "Molla” öneki de bütün isimlerde kullanılmaktadır.

\section{No Kișinin Geldiği Yer}

1 Atça Kazasından gelmiştir

Sene 48 Üzümovalı

2 Bozdoğan Kazasından gelmiştir Sene 52 Çoban İsa Karyeli

\section{Fiziksel Özellikleri}

Kisa Boylu Kumral

Sakallı

Orta Boylu Kumral

Sakallı
İsim

Hüseyin Dayı oğlu Molla Ahmed bin Hüseyin

Ak Mehmed oğlu Molla

Ali bin Mehmed

Yaş

${ }^{33}$ BOA, NFS.d. 3013, s. 7-8.

${ }^{34}$ Çiğdem taş, a.g.t., s. 81 .

35 BOA, NFS.d. 3013, s. 8.

${ }^{36}$ Çiğdem Taş, a.g.t., 77; Abdulhalim Durma, a.g.e., s. 41. 


\section{Veysi Paşa Medresesi ${ }^{37}$}

Veysi Paşa tarafindan yaptırılan Veysi Paşa Medresesi'nin 1898, 1899, 1900, 1901 ve 1903 yıllarında müderrisliğini Hüseyin Efendi yapmaktadır. Hisar Mahallesi'nde bulunan bu medresenin talebe sayıs $1898^{\prime}$ de beş, 1899 'da yedi olup, 1900 yılında sekiz talebesi bulunmaktadır. Talebe sayılarının 1901'de on iki 1903 'de on bir olduğu görülmektedir. ${ }^{38}$

Defterde Veysi Paşa Medresesi'nde altı kişinin kaydı bulunmaktadır. Sekiz ile 38 yaş aralığına sahip bu kişilerin ortalama yaş seviyesi 18,5' dir. Fiziksel özellik olarak da "Orta Boylu" ve "Şabb-ı Emred” özellikleri göstermektedirler.

“Molla” öneki de bütün isimlerde kullanılmaktadır.

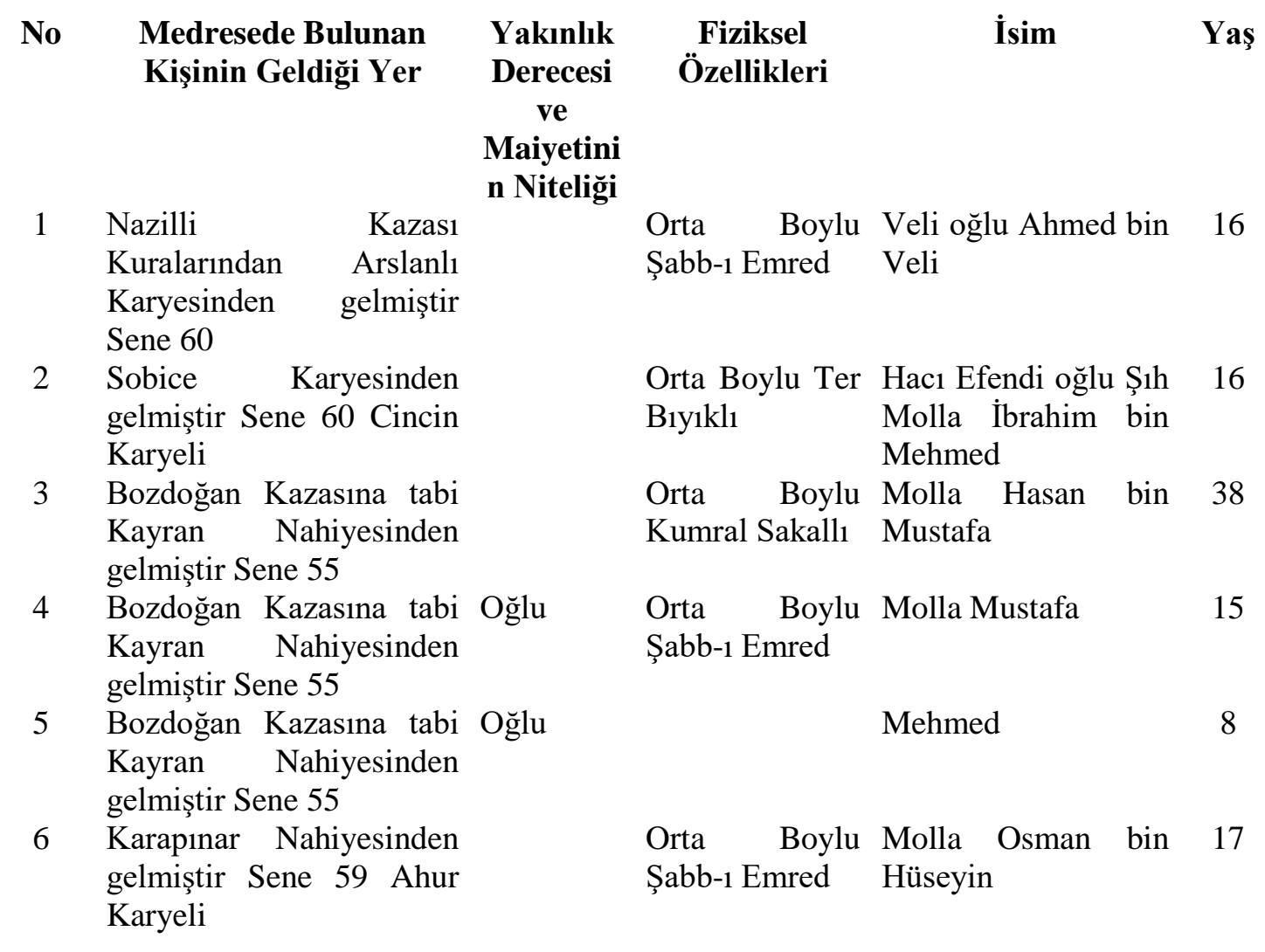

\section{Kubbeli Mescid Medresesi ${ }^{39}$}

Defterde sekiz kişinin kaydı bulunmaktadır. 26 ve 15 yaş aralığına sahip bu kişilerin ortalama yaş seviyesi 19'dur. Fiziksel özellik olarak da "Orta ve Uzun Boylu" ve "Sakallı ve Şabb-ı Emred" özellikleri göstermektedirler.

"Molla" öneki de bütün isimlerde kullanılmaktadır.

\footnotetext{
${ }^{37}$ BOA, NFS.d. 3013, s. 8.

38 Çiğdem Taş, a.g.t., s. 77;. Abdulhalim Durma, a.g.e. s. 41.

${ }^{39}$ BOA, NFS.d. 3013, s. 8.
} 
Medresede Bulunan Kişinin Geldiği Yer

$\mathbf{N}$

o

Kuyucak Kazasından

1 gelmiştir Sene 52

Kuyucak Kazasindan

gelmiştir Sene 56

2 Nazillili

Kuyucak Kazasından

3 gelmiştir Sene 56

Nazilli Kazasından gelmiştir Sene 59 Kestel

4 Karyeli

Nazilli Kazasından

5 gelmiştir Sene 59

Karacasu Kazasindan

gelmiștir Sene 58 Pirbey

6 Karyeli

Karacasu Kazasindan

7 gelmiş̧ir Sene $58 \quad$ Refiki

Karacasu Kazasindan

8 gelmiştir Sene 58
Yakınlık

Derecesi ve

Maiyetinin

Niteliği

Karındaşı

\section{Fiziksel}

Özellikleri

Uzun Boylu Kara

Sakallı

Molla Mustafa bin Ali

25

Uzun Boylu Kara

Sakalli

Molla Halil bin Mehmed

Uzun Boylu Kara

Sakall1

Molla Ahmed bin Osman

26

Orta Boylu Ter Molla Mustafa bin $\begin{array}{lll}\text { Biyıklı Mustafa } & 19\end{array}$

Orta Boylu Şabb-1

Emred Molla Ali

Şabb-1 Emred Mustafa 16

Orta Boylu Şabb-1 Ali Kethüda oğlu Molla

Emred

Ali bin Ali

Orta Boylu Şabb-1 Doğanc1 oğlu Molla

Emred

Ahmed bin İbrahim

16

\section{Cami-i Kebir Medresesi ${ }^{40}$}

Defterimizde dört kişinin kaydı bulunmaktadır. 25 ile 50 yaş aralığına sahip bu kişilerin ortalama yaş seviyesi 31'dir. Fiziksel özellik olarak da "Orta Boylu” ve "Sakallı" özellikleri göstermektedirler. "Molla” öneki de bütün isimlerde kullanılmaktadır.

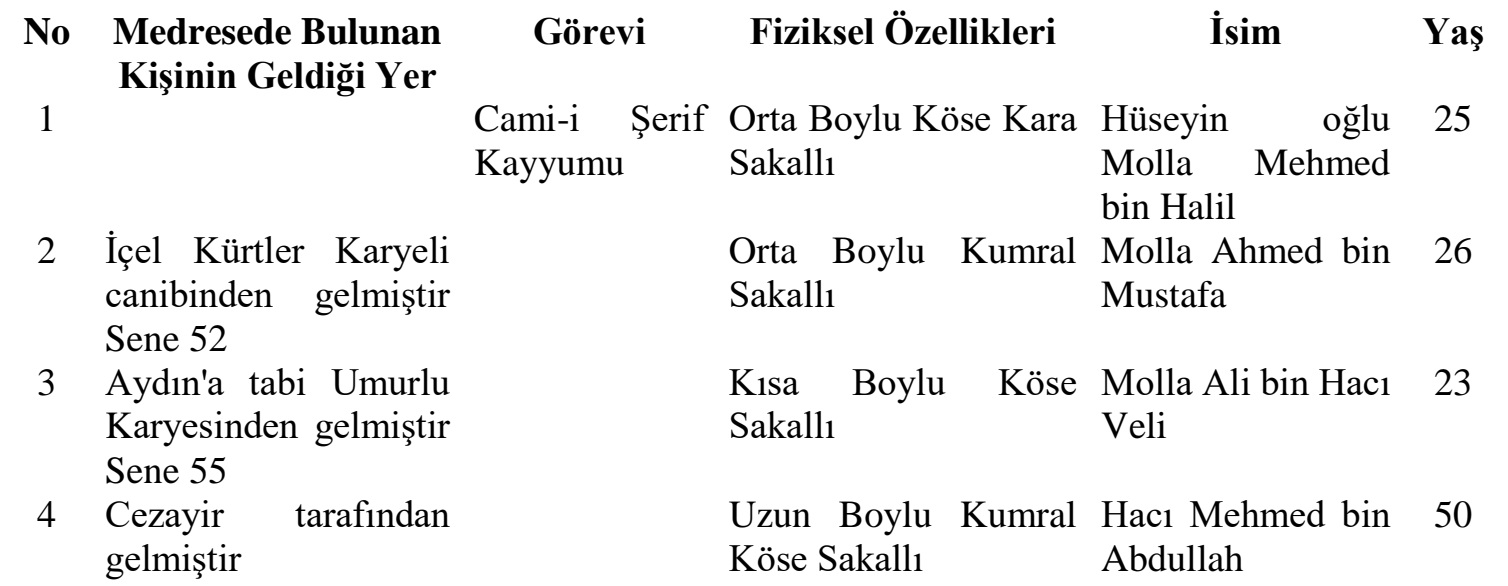

${ }^{40}$ BOA, NFS.d. 3013, s. 9. 


\section{Dayızade Medresesi ${ }^{41}$}

Dayızade Süleyman Ağa tarafından Kapalı Mescit Mahallesi'nde yaptırılmış olan Dayığlu Medresesi'nin, Müftü Hafız Mehmet Emin Efendi'nin müderrisliğinde XX. yüzyılın başlarında talebe sayıs1 20 civarındadır. ${ }^{42}$

Defterde 22 kişinin kaydı bulunmaktadır. 9 ile 30 yaş aralığına sahip bu kişilerin ortalama yaş seviyesi 18'dir. Fiziksel özellik olarak da "Orta Boylu" ve "Sakallı ve Şabb-ı Emred" özellikleri göstermektedirler.

"Mehmed" ismi ağırlıklı olarak kullanılmış ve "Molla" öneki de bütün isimlerde kullanılmaktadır.

\section{No}

\section{Yakınlık \\ Derecesi ve \\ Maiyetinin \\ Niteliği ve \\ Görevi}

\begin{tabular}{|c|c|c|}
\hline & $\begin{array}{l}\text { Konya'ya tabi } \\
\text { Hadimli } \\
\text { Kazasından } \\
\text { gelmiştir Sene } 56\end{array}$ & $\begin{array}{l}\text { Müderris } \\
\text { Vekili }\end{array}$ \\
\hline & $\begin{array}{l}\text { Çine Kazasından } \\
\text { gelmiştir Sene } 59\end{array}$ & Çömezi \\
\hline & $\begin{array}{l}\text { Konya'ya tabi } \\
\text { Hadim Kazasından } \\
\text { gelmiştir Sene } 56\end{array}$ & Çömezi \\
\hline & $\begin{array}{lr}\text { Konya'ya } & \text { tabi } \\
\text { Hadimli } & \text { Kazas1 } \\
\text { canibinden } & \\
\text { gelmiştir Sene } 60\end{array}$ & \\
\hline & $\begin{array}{lr}\begin{array}{l}\text { Konya'ya } \\
\text { Hadimli }\end{array} & \text { tabi } \\
\text { canibinden } & \\
\text { gelmiştir Sene } 60\end{array}$ & \\
\hline & $\begin{array}{lr}\begin{array}{l}\text { Konya'ya } \\
\text { Hadimli }\end{array} & \text { tabi } \\
\text { canibinden } & \\
\text { gelmiştir Sene } 60\end{array}$ & \\
\hline t & $\begin{array}{lr}\begin{array}{l}\text { Konya'ya } \\
\text { Hadimli }\end{array} & \text { tabi } \\
\text { canibinden } & \\
\text { gelmiştir Sene } 60\end{array}$ & \\
\hline & $\begin{array}{l}\text { Konya'ya } \quad \text { tabi } \\
\text { Hadimli } \\
\text { canibinden } \\
\text { gelmiștir Sene } 60\end{array}$ & \\
\hline
\end{tabular}

\section{Fiziksel Özellikleri}

İsim

Yaş

Orta Boylu Abdullah Efendi bin 30

Kumral Sakallı Ahmed

Orta Boylu Kara Berber oğlu Molla Ali bin 22

Sakallı İsmail

81

Orta Boylu Ter Ömer oğlu Molla Mustafa 20

Biyıklı bin Mehmed

Orta Boylu Ter Kalfa oğlu Molla Mehmed 19

Biylklı bin Ahmed

$10 / 2$

April

2020

Orta Boylu Ter Vezir İsmail Efendi oğlu 17 Biyıkl1 Molla Mehmed bin İsmail

Orta Boylu Hacı Abdullah Efendi oğlu 15 Şabb-1 Emred Mehmed bin Abdullah

Orta Boylu Ter Kethüda Hasan oğlu Molla 19

Bıyıklı Hasan bin Hasan

Kısa Boylu Çukadar oğlu Molla Hasan 14

Şabb-1 Emred bin Abdullah

\footnotetext{
${ }^{41}$ BOA, NFS.d. 3013, s. 9.

${ }^{42}$ Çiğdem Taş, a.g.t., s. 78; Abdulhalim Durma, Evliyalar Şehri Aydın, s. 42.
} 


\section{No

Medresede
Bulunan Kişinin
Geldiŏi Yer

Yakınlık

Derecesi ve

Maiyetinin

Niteliği ve

Görevi
82

$10 / 2$

April 2020

\begin{tabular}{|c|c|c|}
\hline 9 & $\begin{array}{lr}\begin{array}{l}\text { Konya'ya } \\
\text { Hadimli }\end{array} & \text { tabi } \\
\text { canibinden } & \\
\text { gelmiştir Sene } 60\end{array}$ & \\
\hline 10 & $\begin{array}{l}\text { Kara Tekeli } \\
\text { Aşiretinden } \\
\text { gelmiștir Sene } 58\end{array}$ & Çömezi \\
\hline 11 & $\begin{array}{l}\text { Kara Tekeli } \\
\text { Aşiretinden } \\
\text { gelmiştir Sene } 58\end{array}$ & Çömezi \\
\hline 12 & $\begin{array}{l}\text { Kara Tekeli } \\
\text { Aşiretinden } \\
\text { gelmiştir Sene } 58\end{array}$ & Çömezi \\
\hline 13 & $\begin{array}{l}\text { Kara Tekeli } \\
\text { Aşiretinden } \\
\text { gelmiştir Sene } 58\end{array}$ & Çömezi \\
\hline 14 & $\begin{array}{l}\text { Kara Tekeli } \\
\text { Aşiretinden } \\
\text { gelmiştir Sene } 58\end{array}$ & Çömezi \\
\hline 15 & $\begin{array}{l}\text { Kara Tekeli } \\
\text { Aşiretinden } \\
\text { gelmiştir Sene } 58\end{array}$ & Çömezi \\
\hline 16 & $\begin{array}{l}\text { Konya'ya } \\
\text { Hadimli } \\
\text { canibinden } \\
\text { gelmiștir Sene } 60\end{array}$ & \\
\hline 17 & $\begin{array}{l}\text { Konya canibinden } \\
\text { gelmiştir Sene } 58\end{array}$ & \\
\hline 18 & $\begin{array}{l}\text { Konya canibinden } \\
\text { gelmiştir Sene } 58\end{array}$ & Karındaşı \\
\hline 19 & $\begin{array}{l}\text { Mazon } \quad \text { Kazasi }^{43} \\
\text { Kesir } \\
\text { gelmiştir }\end{array}$ & \\
\hline 20 & $\begin{array}{l}\text { Mazon Kazasından } \\
\text { gelmiştir Sene } 52\end{array}$ & Refiki \\
\hline 21 & $\begin{array}{l}\text { Bozkır Kazası } \\
\text { canibinden } \\
\text { gelmiştir Sene } 59\end{array}$ & \\
\hline & $\begin{array}{l}\text { İçel canibinden } \\
\text { gelmiştir Sene } 59\end{array}$ & \\
\hline
\end{tabular}

\section{Fiziksel \\ Özellikleri}

İsim

Yaş

Orta Boylu Kara Demirci oğlu Molla 26

Sakallı Mehmed Emin bin

Mehmed

Orta Boylu Ter Hacı Halil oğlu Molla 16 Bıyıklı Mehmed bin Halil

Hac1 Mehmed oğlu Molla 13

Hasan bin Mehmed

Hacı Hasan oğlu Molla 12

Hüseyin bin Hasan

Hac1 Musa oğlu Molla 11

Mehmed bin Hacı Kerim

Deli Yusuf oğlu Molla 10

Hüseyin bin Mahmud

... oğlu Molla İbrahim bin 9

Mehmed Ali

Orta Boylu ... oğlu Molla Mehmed bin 24

Kumral Sakallı Mustafa

Uzunca Boylu Semerci oğlu Molla 20

Kumral Sakallı Mustafa bin Abdulbaki

Uzunca Boylu Molla Mahmud 22

Ter Bıyıklı

Orta Boylu Ter Molla Hasan bin Mehmed 22 Biyıkl1

Orta Boylu Molla Hüseyin bin Hüseyin 16

Şabb-1 Emred

Orta Boylu İsa oğlu Molla Mehmed bin 23

Kumral Sakallı İsa

Orta Boylu Mehmed Efendi oğlu Molla 23

Köse Sakallı Ali bin Mehmed

\footnotetext{
${ }^{43}$ Mazon, Koçarlı (Bafa gölünün kuzeybatısında).
} 


\section{Alihan Medresesi ${ }^{44}$}

Pir Hüsnü Mahallesi'ndeki Alihan-1 Kebir Medresesi Muhiddin Efendi tarafindan yaptırılmıştır. Ahmet Efendi'nin müderrislik yaptığ 1898 yılında medresede 40 talebe bulunurken 1899 yılına ait salnamede bu sayı 45'e yükselir. Ahmet Efendi'nin müderrisliğinin devam ettiği 1900 yllında 30 talebe, 1901 ve 1903'te de 34'er talebe medresede eğitim görmektedir. ${ }^{45}$

Defterimizde dört kişinin kaydı bulunmaktadır. 16 ile 35 yaş aralığına sahip bu kişilerin ortalama yaş seviyesi 23'dür. Fiziksel özellik olarak da "Orta Boylu" ve "Müzellef ve Şabb-l Emred" özellikleri göstermektedirler.

"Mustafa" ismi ağırlıklı olarak kullanılmış ve "Molla ve Hacl” öneki de bütün isimlerde kullanilmaktadır.

\begin{tabular}{|c|c|c|c|}
\hline No & $\begin{array}{l}\text { Medresede Bulunan Kişinin } \\
\text { Geldiği Yer }\end{array}$ & Fiziksel özellikler & m \\
\hline 1 & $\begin{array}{l}\text { Mandalyad Kazası canibinden } \\
\text { gelmiştir Sene } 57\end{array}$ & $\begin{array}{l}\text { Orta Boylu Kumral } \\
\text { Sakallı }\end{array}$ & $\begin{array}{l}\text { Mustafa } \\
\text { Mehmed }\end{array}$ \\
\hline 2 & $\begin{array}{l}\text { Mazon Kazasından gelmiştir } \\
\text { Sene } 50\end{array}$ & $\begin{array}{l}\text { Orta Boylu Müzellef } \\
\text { Sakallı }\end{array}$ & Molla Mustafa bin Mehmed \\
\hline 3 & $\begin{array}{l}\text { Mazon Kazasına tabi Kesir } \\
\text { Karyesinden gelmiştir Sene } 57\end{array}$ & $\begin{array}{l}\text { Orta Boylu Ter } \\
\text { Biyıklı }\end{array}$ & $\begin{array}{l}\text { Hacı İmam oğlu Molla } \\
\text { Osman bin Mehmed }\end{array}$ \\
\hline 4 & $\begin{array}{lrr}\text { Bodrum } & \text { Kazasına tabi } \\
\text { Sandırma } & \text { (Sandıma) } \\
\text { Karyesinden } & \text { gelmiştir Sene } 57\end{array}$ & $\begin{array}{l}\text { Orta Boylu Şabb-1 } \\
\text { Emred }\end{array}$ & $\begin{array}{l}\text { Hatib Haci } r \text { Bekir } \\
\text { Efendizade } \\
\text { bin Bekir }\end{array}$ \\
\hline
\end{tabular}

\section{Eski Yeni Medresesii ${ }^{46}$}

Aydın Güzelhisarı'nın en eski ve soylu ailelerinden Mevlana Kadı Nazır Muhiddin Çelebi'nin oğulları Üveys, Ramazan ve Hasan Çelebiler Güzelhisar'da önemli eserler bırakmışlardır. ${ }^{47}$ Eski Yeni Medresesi 1585 yılında Üveys Paşa'nın kardeşi Hasan Çelebi tarafından yaptırılmıştır. Hasan Efendi Mahallesi'nde bulunmaktadır.

Defterde Eski Yeni Medrese'ye ait yedi kişinin kaydı bulunmaktadır. 18 ile 65 yaş aralığına sahip bu kişilerin ortalama yaş seviyesi 39'dur. Fiziksel özellik olarak da "Orta Boylu” ve "Sakallı" özellikleri göstermektedirler.

"Molla ve Hacl” öneki de bütün isimlerde kullanılmaktadır.

\footnotetext{
${ }^{44}$ BOA, NFS.d. 3013, s. 9.

${ }^{45}$ Çiğdem Taş, a.g.t., s. 77; Abdulhalim Durma, a.g.e. s. 41.

46 BOA, NFS.d. 3013, s. 10.

47 Üveys Paşa ailesi hakkında ayrıntılı bilgi için bkz. M. Tayyib Gökbilgin, "Kara Üveys Paşa'nın Budin Beylerbeyliği (1578-1580)", Tarih Dergisi, c. II, S. 3-4, İstanbul 1952, ss. 17-34.
} 


\begin{tabular}{|c|c|c|c|}
\hline No & $\begin{array}{c}\text { Medresede } \\
\text { Bulunan Kişinin } \\
\text { Geldiği Yer } \\
\text { Mücavir Rumeli }\end{array}$ & Fiziksel Özellikler & İsim \\
\hline 1 & $\begin{array}{l}\text { Zağralı } \\
\text { Alaiye Canibinden }\end{array}$ & Orta Boylu Sarı Kır Sakallı & Hacı Ahmed Efendi bin Abdullah \\
\hline 2 & $\begin{array}{l}\text { gelmiştir Sene } 50 \\
\text { Mücavir }\end{array}$ & Orta Boylu Kır Sakallı & Hacı Hasan Efendi bin Mehmed \\
\hline 3 & Köşkdereli & Orta Boylu Ak sakallı & Hacı Molla Mehmed bin Mehmed \\
\hline 4 & $\begin{array}{l}\text { Isparta Kazası } \\
\text { canibinden gelmiş }\end{array}$ & Orta Boylu Sarı Sakallı & Pirli Molla Bekir bin Süleyman \\
\hline 5 & $\begin{array}{l}\text { Sene } 59 \\
\text { Isparta Kazas1 } \\
\text { canibinden gelmiş }\end{array}$ & Orta Boylu Ter Bıyıklı & Hafız Mustafa bin Mehmed \\
\hline 6 & $\begin{array}{l}\text { Sene } 59 \\
\text { Birgi Kazasına tabi } \\
\text { Bademiye } \\
\text { Karyesinden }\end{array}$ & Orta Boylu Kara Sakallı & Hafiz Osman bin Mustafa \\
\hline
\end{tabular}

\section{$84 \quad$ Abacizade Medresesi ${ }^{48}$}

Çarşiç̧i Mahallesi'nde bulunan Abacıoğlu Medresesi Abacızade Hacı Mustafa Ağa tarafından yaptırılmıştır. Müftizade Mustafa Efendi'nin müderrisliği dönemindeki 1898 ve 1899 yıllarında talebe sayısı 30'dur. Mustafa Efendi'nin 32 olan talebe sayısı, 1901 ve 1903 yıllarında 36'ya yükselmiştir. ${ }^{49}$

Defterde 22 kişinin kaydı bulunmaktadır. 13 ile 53 yaş aralığına sahip bu kişilerin ortalama yaş seviyesi 23,5'dur. Fiziksel özellik olarak da "Orta Boylu” ve "Sakallı" özellikleri göstermektedirler.

"Mehmed ve Mustafa" isimleri ağıllıkta olup, "Molla" öneki ile birlikte isimlerden sonra "Efendi" de sonek olarak kullanılmaktadır.

Bu medreseye gelenlerde Sultanhisar ve Çine kaynaklıdırlar.

\footnotetext{
${ }^{48}$ BOA, NFS.d. 3013, s. 10.

${ }^{49}$ Çiğdem Taş, a.g.t., s. 81; Abdulhalim Durma, a.g.e, s. 46.
} 


\section{No Medresede Bulunan Kişinin Geldiği Yer}

2 Sultanhisarı Kazasından gelmiştir Sene 57

Eskihisarlı

3 Sultanhisarı Kazasından gelmiştir Sene 60

Eskihisarlı

4 Sultanhisarı Kazasından gelmiştir Sene 60

Eskihisarl1

5 Sultanhisarı Kazasından gelmiştir Sene 60 Kavaklı Karyeli

6 Sultanhisarı Kazasından gelmiştir Sene 60 Kavaklı Karyeli

7 Sultanhisarı Kazasından Karındaşı gelmiştir Sene 60

8 Akçaabad Kazası canibinden gelmiștir Sene 60

9 Sultanhisarı Kazasından gelmiştir Sene 60 Kavaklı Karyeli

10 Yenipazar Kazasından gelmiştir Sene 60

11 Yenipazar Kazasindan gelmiştir Sene 60

12 Sultanhisarı Kazasından gelmiştir Sene 61 Eskihisarlı

13 Çine Kazasından gelmiştir Sene 54

14 Cine Kazasına tabi Akçaabad'dan gelmiștir Sene 57

15 Çine Kazasına tabi Akçaabad'dan gelmiştir Sene 57

Refiki

Karındaşı

\section{Yakınlık \\ Derecesi ve \\ Maiyetinin \\ Niteliği ve \\ Görevi \\ Özellikler}

İsim

Ya

ş

Orta Boylu Ak

Sakallı

Orta Boylu Kır

Sakallı

Orta Boylu Ter

Biyıkl1

Orta Boylu Ter

Biyıklı

Orta Boylu Ter

Biyıklı

Orta Boylu Ter

Bıyıklı

Orta Boylu

Şabb-1 Emred

Orta Boylu Ter

Biyıklı

Orta Boylu

Sabb-1 Emred

Pirli Kayyum

Molla Ahmed bin

Süleyman

Ali Efendi bin

50

Arap Hasan

Molla Mehmed

bin Ahmed

Köse oğlu Molla

Ahmed bin

Süleyman

Pehlivan oğlu

Molla Yusuf bin

Halil

Ali oğlu Molla

Mehmed bin Ali

Mustafa bin Ali

Molla Mehmed

bin Mahmud

Molla Bayram bin

14

Halil

Orta Boylu

Müzellef sarı

Molla Hüseyin bin

Hüseyin

Sakallı

Orta Boylu

Molla Hasan

Şabb-1 Emred

Orta Boylu Ter

Kumral Bıyıklı

Molla Hüseyin bin 23

Mustafa

Uzun Boylu

Arabacı oğlu

Köse Kumral

Mehmed Efendi

Sakalli

bin Süleyman

Orta Boylu Kara

Sakallı

Müftü zade

Abdullah Efendi

bin Mustafa

Orta Boylu

Molla Mustafa
85

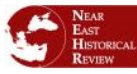

$10 / 2$

April 2020 
No Medresede Bulunan Kişinin Geldiği Yer

\section{Yakınlık \\ Derecesi ve \\ Maiyetinin \\ Niteliği ve \\ Görevi}

16 Çine Kazasına tabi

Kahraman Karyesinden

gelmiştir Sene 57

17 Çine Kazasına tabi Ancin

Karyesinden gelmiştir

Sene 57

18 Çine Kazasına tabi

Bölüntü Karyesinden gelmiştir Sene 54

19 Çine Kazasına tabi Dereli Karyesinden gelmiştir Sene 52

20 Seferli olup ba-tezkere der-aliyyeden gelmiştir Sene 60

21 Çine Kazasından gelmişstir Sene 60

22 Sultanhisarı Kazasından gelmiştir Sene 60
Fiziksel

Özellikler

İsim

Ya

Ş

\begin{tabular}{|c|c|}
\hline $\begin{array}{l}\text { Orta Boylu } \\
\text { Kumral sakallı }\end{array}$ & $\begin{array}{l}\text { Yusuf Ali oğlu Ali } \\
\text { Efendi bin Hasan }\end{array}$ \\
\hline Orta Boylu & Molla Mustafa bin \\
\hline $\begin{array}{l}\text { Müzellef Kumral } \\
\text { Sakallı }\end{array}$ & Ali \\
\hline Uzun Boylu & Hacı Ali oğlu \\
\hline Müzellef Sakallı & $\begin{array}{l}\text { Molla Mehmed } \\
\text { bin Ali }\end{array}$ \\
\hline Kisa Boylu & Mehmed oğlu \\
\hline Müzellef Kumral & Molla Mehmed \\
\hline Sakallı & bin Mehmed \\
\hline Uzunca Boylu & Ali Efendi bin \\
\hline Köse Kara & Sadi \\
\hline $\begin{array}{l}\text { Sakalli } \\
\text { Orta Boylu }\end{array}$ & Molla Mu \\
\hline $\begin{array}{l}\text { Müzellef Kumral } \\
\text { Sakallı }\end{array}$ & Ali \\
\hline Orta Boylu Ter & Molla Hasan bin \\
\hline Kara Biyıklı & Halil \\
\hline
\end{tabular}

\section{Ramazan Paşa Medresesi ${ }^{50}$}

Üveys Paşa'nın kardeşi Ramazan Paşa tarafından yaptırılan Ramazan Paşa Medresesi ismini aldığı Ramazan Paşa Mahallesi'nde bulunmaktadır. Aydınlı Hilmi Efendi'nin müderrisliği zamanında 15 talebesi olan medresenin 1899 y1lna ait Maarif Salnamesi'nde 12 talebesi bulunduğundan söz edilmektedir. 1900, 1901 ve 1903 yıllarında ise 14 talebesi bulunmaktadır. ${ }^{51}$

Defterde 6 kişinin kaydı bulunmaktadır. 22 ile 60 yaş aralığına sahip bu kişilerin ortalama yaş seviyesi 35'dir. Fiziksel özellik olarak da "Orta Boylu" ve "Sakallı" özellikleri göstermektedirler.

"Mehmed" ismi ağırlıkta olup, "Molla" öneki isimlerde kullanılmaktadır.

\section{No Medresede Bulunan Kişinin Geldiği Yer \\ 1 \\ 2 Aydınlı \\ Köşkdereli Kazasından \\ 3 gelmiştir Sene 56}

Fiziksel Özellikler

11

\section{İsim}

Pirli Kayyum Mehmed

Orta Boylu Kır Sakallı Efendi bin Süleyman Orta Boylu Kara

Sakalli

Orta Boylu Kara

Sakallı
Mehmed Efendi bin Ali

Molla Halil bin Mehmed
Ya

${ }^{50}$ BOA, NFS.d. 3013, s. 11.

51 Çiğdem Taş, a.g.t., s. 84; Abdulhalim Durma, a.g.e., s. 7. 


\section{No Medresede Bulunan Kişinin Geldiği Yer \\ 4 Mücavir Köşkdereli \\ 5 Aydinlı \\ Rumeli Yenişehir Kazası \\ 6 canibinden gelmiştir}

Fiziksel Özellikler

Orta Boylu Kara

Sakallı

Orta Boylu Köse

Sakall1

Orta Boylu Sarı Köse

Sakallı
İsim

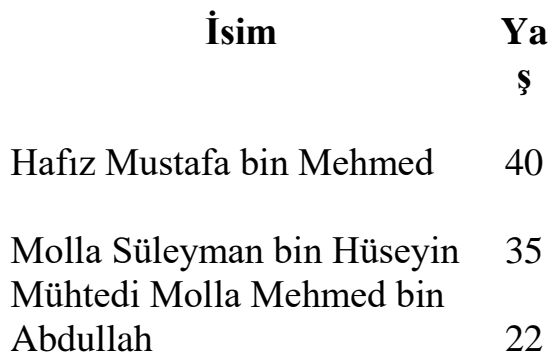

40

35

22

\section{Yukarı ve Aşağı Zeynzade Medresesi ${ }^{52}$}

Osmanlı medreselerinde okutulan nahiv klasiklerinden el-Avamil, İzharü'l-esrar ve elKafiye'ye yazdığı mu'rib kitaplarıyla tanınan Arap dili âlimi Zeynizade Hüseyin Efendi XVIII. yüzyılın başlarında İzmir Tire'de dünyaya gelmiştir (Ö.1759). Zeynizade lakabıyla tanınır. İlk eğitimini Tire'de alır. Tahsilini ilerletmek için dönemin ilim merkezlerinden olan, günümüzde Aydın'ın bir mahallesi durumundaki Güzelhisar kasabasına yerleşir. Bunun yanında Aydın'ın Koçarlı ilçesine üç km. mesafedeki Sobuca Kasabası'nda da öğrenim görür. Zeynizade "hocamız, üstadımız, şeyhimiz" olarak nitelediği Sobucalı (Sobicevi) Mehmed Efendi'den çok faydalanmıştır. Güzelhisar'da müderrislik yapmıştır. ${ }^{53}$

Defterde Zeynzade Medresesi'ne ait dördü yukarı medrese ve üçü de aşağı medresede olmak üzere 7 kişinin kaydı bulunmaktadır. 12 ile 65 yaş aralığına sahip bu kişilerin ortalama yaş seviyesi 30'dur. Fiziksel özellik olarak da "Orta Boylu" ve "Sakallı" özellikleri göstermektedirler.

“Mehmed" ismi ağırlıkta olup, "Molla" öneki isimlerde kullanılmaktadır.

\section{No Medresede Bulunan Kişinin Geldiği Yer}

\section{Fiziksel \\ Özellikler}

İsim

Derecesi ve

Maiyetinin

Niteliği ve

Görevi
1 Mücavir Koçak

Kazasindan

2 Koçak Kazasından Çömezi gelmiştir Sene 60

Kavakl1 Karyeli

3 Aydinlı

4 Mücavir Moralı
Orta Boylu Kara Kara Molla Mehmed 43

Sakallı bin Mehmed

Molla Mehmed bin 12

Mehmed

Orta Boylu Pirli Molla Ömer bin 22

Müzellef Sakallı Abdulah

Orta Boylu Sar1 Molla Salih bin 22

Sakallı

Osman

Kısa Boylu Ak Pirli Molla İbrahim 65 bin Mustafa

\footnotetext{
52 BOA, NFS.d. 3013, s. 11.

${ }^{53}$ Abdulhalim Durma, a.g.e., s. 19.
} 


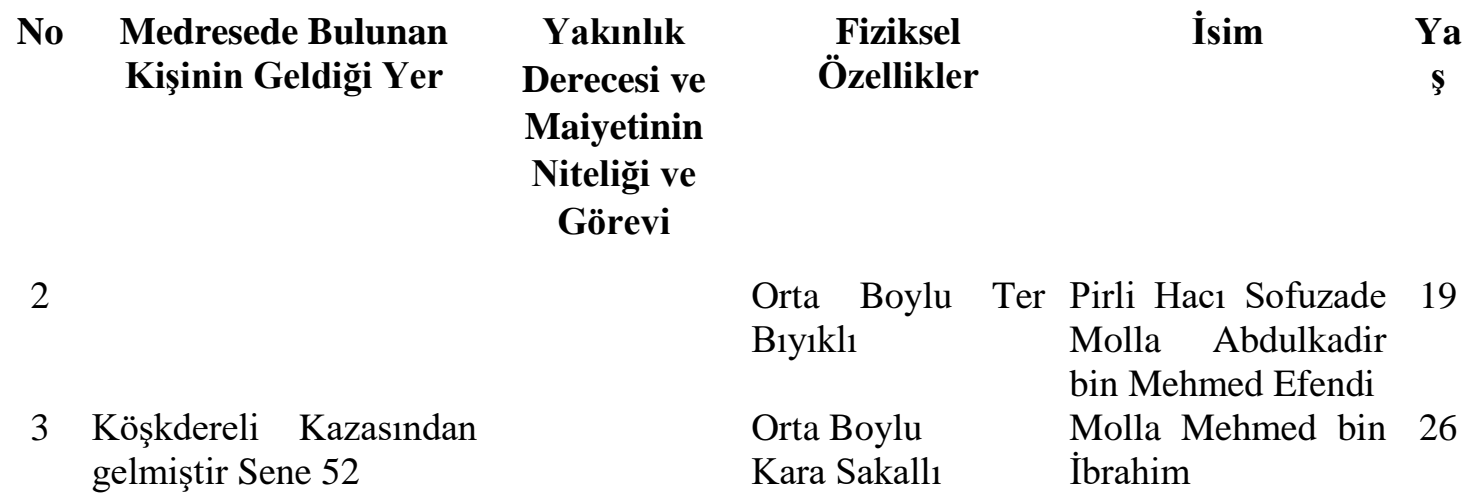

\section{Bey Medresesi ${ }^{54}$}

Defterde 20 kişinin kaydı bulunmaktadır. Sekiz ile 60 yaş aralığına sahip bu kişilerin ortalama yaş seviyesi 29'dur. Fiziksel özellik olarak da "Orta Boylu” ve "Sakallı" özellikleri göstermektedirler.

“Mehmed, Hüseyin, Ali” ismi ağırlıkta olup, "Molla” öneki ile birlikte isimlerden sonra "Efendi" de sonek olarak kullanılmaktadır.

\section{8}

No Medresede Bulunan Kişinin Geldiği Yer

10 / 2

April

2020

1 Aydınl
2 Nazilli Kazasından gelmiştir Sene 60

3 Kibris canibinden gelip Aydın'da mücavir kalmıştır Sene 53

4 Isparta canibinden gelip Aydın'da mücavir kalmıştır Sene 35

5

6

7 Sultanhisarı Kazasından gelmiştir Sene 58 Salavatl1 Karyeli

8 Manisa canibinden gelmiştir Sene 56 Kasabalı

\section{Yakınlık \\ Derecesi ve \\ Maiyetinin \\ Niteliği ve \\ Görevi \\ Müderris}

Vekili

Fiziksel Özellikleri

İsim

Yaş

\section{Ozelikleri}

Orta Boylu

Kır Sakallı

Orta Boylu

Kır Sakallı

Orta Boylu

Ak Sakallı

Uzun Boylu

Kır Sakallı

Orta Boylu

Kara Sakallı

Orta Boylu

Kumral Sakallı

Orta Boylu

Müzellef

Sakall1

Orta Boylu

Müzellef

Sakallı
Berber oğlu
Mustafa Efendi bin Mehmed

Veliüddin Efendi 42

bin Ali

Hac1 Mehmed

Efendi bin

Abdullah

Hac1 Molla

Hüseyin bin Osman

Pirli Hafiz İbrahim

45

Efendi bin Hac1

Mehmed

Müezzin Pirli Hac1 34

Hüseyin bin Ali

Molla Mehmed bin 25

Ahmed

Hacı Veli oğlu Hacı

Mehmed bin Hac1

Osman

\footnotetext{
${ }^{54}$ BOA, NFS.d. 3013, s. 12.
} 
9 Çine Kazasına tabi Kara oğullar Karyesinden gelmişdir Sene 52

10 Çine Kazasına tabi Kara oğullar Karyesinden gelmişdir Sene 52

12 Milas Kazası canibinden gelmiş Sene 58

13 Karpuzlu Kazasından gelmiştir Sene 57

14 Karpuzlu Kazasından Refiki gelmiştir Sene 57

15 Çine Kazasından gelmiştir Sene 50

16 Çine Kazasından Biraderzadesi gelmiştirS 50

17 Karahayit Kazasina tabi ... Karyesinden gelmiştir Sene 60

18 Karahayit Kazasına tabi ... Karyesinden gelmiştir Sene 60

19 Karahayit Kazasina tabi ... Karyesinden gelmiştir Sene 60

20 Nefs-i Karahayit Refiki

Kazasından gelmiştir Sene 60

Çömezi

\section{Uzun Boylu \\ Kara Sakallı \\ Uzun Boylu \\ Kara Sakallı}

Aydınlı

oğlu

Mehmed Emin

Efendi bin Mehmed

Ali Efendi

Molla Mehmed bin Yusuf

Kisa Boylu

Müzellef

Sakalli

Kisa Boylu

Müzellef

Sakallı

Kisa Boylu

Ter Bıyıklı

Orta Boylu

Kirca Sakallı

Tokadi oğlu Fettah

bin Hüseyin

Küçük Osman oğlu

Molla Ali bin

Osman

Hacı İmam oğlu

Molla Hüseyin bin

İbrahim

Sarı Ahmed oğlu

Molla Osman

Efendi bin İsmail

Molla İbrahim bin 9

Mehmed

Orta Boylu

Deli oğlu Mustafa 36

89

Kara Sakallı

Efendi bin Ali

Molla Ali bin 11

Hüseyin

$10 / 2$

Ahmed bin Hüseyin $\quad 8$

April

2020

\section{Zincirli nam-ı diğer Kozdibi Medresesi ${ }^{55}$}

Kozdibi Mahallesi'nde bulunan Aşağı Zincirli Medresesi iane ile yapılmıştır. Şükrü Efendi'nin müderrisliği döneminde sekiz talebesi olan medresenin 1899 yılına ait salnamede 20 talebesi bulunmaktadır. 1900'de 10, 1901 ve 1903 'de 16 talebe eğitim görmektedir. ${ }^{56}$

Defterde dört kişinin kaydı bulunmaktadır. 18 ile 75 yaş aralığına sahip bu kişilerin ortalama yaş seviyesi 34,5'dur. Fiziksel özellik olarak da "Orta Boylu” ve "Sakallı" özellikleri göstermektedirler.

"Mehmed" ismi ağırlıkta olup, "Molla” öneki ile birlikte kullanılmaktadır.

\footnotetext{
55 BOA, NFS.d. 3013, s. 12

${ }^{56}$ Abdulhalim Durma, a.g.e., s. 44.
} 


\begin{tabular}{clllc} 
No & \multicolumn{1}{c}{$\begin{array}{c}\text { Medresede Bulunan } \\
\text { Kişinin Geldiği Yer }\end{array}$} & Fiziksel Özellikleri & \multicolumn{1}{c}{ İsim } & $\begin{array}{c}\text { Ya } \\
\text { ş }\end{array}$ \\
1 & $\begin{array}{l}\text { Sobice Kazasından gelip } \\
\text { Aydın'da mücavir } \\
\text { kalmış Sene 35 }\end{array}$ & Orta Boylu Ak Sakallı & $\begin{array}{l}\text { Hacı Mehmed Efendi bin } \\
\text { Hüseyin }\end{array}$ & 75 \\
2 & Orta Boylu Ter Bıyıklı & Pirli Kara Ali oğlu Molla \\
Mehmed bin Halil & 20 \\
3 & $\begin{array}{l}\text { Şahme Kazasından } \\
\text { gelmiştir Sene 59 }\end{array}$ & $\begin{array}{l}\text { Orta Boylu Müzellef } \\
\text { sakallı }\end{array}$ & Molla Hüseyin bin Süleyman & 25 \\
4 & $\begin{array}{l}\text { Şahme Kazasından } \\
\text { gelmiştir Sene 56 }\end{array}$ & $\begin{array}{l}\text { Orta Boylu Şabb-1 } \\
\text { Emred }\end{array}$ & Molla Mustafa Ali bin Mehmed & 18
\end{tabular}

\section{Çelik Paşa Medresesi ${ }^{57}$}

Terziler Mahallesi'nde bulunan Çelik PaşA Medresesi Halil Paşa tarafından yaptırılmıştır. 1898 ve 1899 yıllarında müderris Mehmet Efendi döneminde 12 talebeye sahip olan medresenin, 1900, 1901 ve 1903 yılları arasında Müderris Memiş Efendi zamanında 18 talebesi bulunmaktadir..$^{58}$

Defterde dokuz kișinin kaydı bulunmaktadır. 18 ile 75 yaş aralığına sahip bu kișilerin ortalama yaş seviyesi 32,5'dur. Fiziksel özellik olarak da "Orta Boylu" ve "Sakallı" özellikleri göstermektedirler.

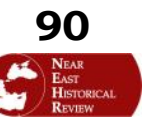

$10 / 2$ April 2020

"Mehmed" ismi ağırlıkta olup, "Molla" öneki ile birlikte kullanılmaktadır.

\begin{tabular}{|c|c|c|c|}
\hline No & $\begin{array}{l}\text { Medresede Bulunan } \\
\text { Kişinin Geldiği Yer }\end{array}$ & Fiziksel Özellikleri & İsim \\
\hline 1 & $\begin{array}{l}\text { Karahayıt Kazasından } \\
\text { gelmiștir Sene } 52\end{array}$ & $\begin{array}{l}\text { Orta Boylu } \\
\text { Kara Sakallı }\end{array}$ & $\begin{array}{l}\text { Pehlivan oğlu Mehmed Efendi } \\
\text { bin Hasan }\end{array}$ \\
\hline 2 & $\begin{array}{l}\text { Mandalyad Kazasindan } \\
\text { Sene } 57\end{array}$ & $\begin{array}{l}\text { Orta Boylu } \\
\text { Kir Sakallı }\end{array}$ & $\begin{array}{l}\text { Osman oğlu Molla Mehmed Ali } \\
\text { bin Mustafa }\end{array}$ \\
\hline 3 & $\begin{array}{l}\text { Birgi Kazasina tabi } \\
\text { Mendime Karyesinden } \\
\text { gelmiştir Sene } 55\end{array}$ & $\begin{array}{l}\text { Orta Boylu Kumral } \\
\text { Sakall } 1\end{array}$ & $\begin{array}{l}\text { Hacı İsmail oğlu Molla Hüseyin } \\
\text { bin İsmail }\end{array}$ \\
\hline 4 & $\begin{array}{l}\text { Mandalyad Kazasindan } \\
\text { Sene } 54\end{array}$ & Kisa Boylu Ak Sakallı & $\begin{array}{l}\text { Hac1 Abdurrahman Efendi bin } \\
\text { Mehmed }\end{array}$ \\
\hline 5 & $\begin{array}{lr}\text { Koçak } & \text { Nahiyesinden } \\
\text { gelmiştir } & \text { Sene } \\
\text { Eğrikavaklı } & \end{array}$ & $\begin{array}{l}\text { Orta Boylu Müzellef } \\
\text { Kara Sakallı }\end{array}$ & Hatibzade Molla Ali bin Mustafa \\
\hline 6 & $\begin{array}{l}\text { Koçak Nahiyesinden } \\
\text { gelmiştir Sene } 54\end{array}$ & $\begin{array}{l}\text { Orta Boylu Müzellef } \\
\text { Kara Sakallı }\end{array}$ & $\begin{array}{l}\text { Sülek oğlu Molla Mehmed bin } \\
\text { Hasan }\end{array}$ \\
\hline 7 & ... gelmiştir Sene 55 & $\begin{array}{l}\text { Orta Boylu Şabb-1 } \\
\text { Emred }\end{array}$ & $\begin{array}{l}\text { Hatib oğlu Molla Halil bin } \\
\text { Hüseyin }\end{array}$ \\
\hline 8 & ... gelmiştir Sene 56 & $\begin{array}{l}\text { Orta Boylu Müzellef } \\
\text { Kumral Sakallı }\end{array}$ & $\begin{array}{l}\text { Kocabaş oğlu Molla Ahmed bin } \\
\text { Mehmed }\end{array}$ \\
\hline 9 & $\begin{array}{ll}\text { Aydın'a tabi } & \text { Tekeli } \\
\text { Karyesinden } & \text { gelmiş } \\
\text { Sene 60 } & \end{array}$ & $\begin{array}{l}\text { Orta Boylu Kara } \\
\text { Sakallı }\end{array}$ & $\begin{array}{l}\text { Hacı Hasan oğlu Molla Ömer bin } \\
\text { Hasan }\end{array}$ \\
\hline
\end{tabular}

\footnotetext{
${ }^{57}$ BOA, NFS.d. 3013, s. 13.

${ }^{58}$ Çiğdem Taş, a.g.t., s. 79; Abdulhalim Durma, a.g.e., s. 44.
} 


\section{Ăgaçarası nam-ı diğer Ahmed Paşa Medresesi ${ }^{59}$}

1659 tarihli Ağaçarası Camii, Büyük Menderes Caddesinde olup, Ahmet Şemsi Paşa tarafından yaptırılmıştır. Ağaçarası Camii'nin minaresi kırmızı tuğladan yapıldığı için Kırmızı Minareli Cami adını da almıştır. Caminin avlusunda daha önceki dönemlerde medrese odaları ve mektep bulunmaktayken büyük Aydın depreminde medrese odaları ve mektep yanmış, yanık duvarların daha sonra yıkılması ile birlikte de kitabesi kaybolmuştur. Dönemin müderrisi olan Mehmet Bey'in 1898 yılında dokuz talebesi bulunurken, 1899'da bu sayı sekize inmiştir. 1900, 1901 ve 1903 yıllarında Müderris Salih Efendi'nin sekiz talebesi vardır. ${ }^{60}$

Defterde 15 kişinin kaydı bulunmaktadır. 15 ile 32 yaş aralığına sahip bu kişilerin ortalama yaş seviyesi 21'dir. Fiziksel özellik olarak da "Orta Boylu" ve "Sakallı" özellikleri göstermektedirler.

"Mustafa" ismi ağırlıkta olup, "Molla" öneki ile birlikte kullanılmaktadır.

No

Medresede Bulunan
Kişinin Geldiği Yer

Kişinin Geldiği Yer

Yakınlık

Derecesi

ve

Maiyetinin

Niteliği ve

Görevi

\section{Fiziksel \\ Özellikleri}

İsim Ya Ş
1 Balad Abad Kazasindan gelmiştir Sene 55 Bağarası Karyeli

2 Sobice Kazasından gelmiştir Sene 58

3 Çine Abad Kazasıdan gelmiştir Sene 54 Kırk 1şıklı Karyeli

4 Sobice Kazasından gelmiştir Sene 59 Madran Dereli

5 Koçak Nahiyesinden gelmiştir Sene 55 Bey Karyeli

6 Koçak Nahiyesinden gelmiştir Sene 54 Yukarı Koçaklı

7 Şahme Kazasından gelmiştir Sene 61 Sarban Dereli

8 Koçak Nahiyesinden gelmiştir Sene 58 Kuyucular Karyeli
Orta Boylu Şabb-1 Molla İbrahim bin 15 Emred Hizır

Sarayköylü Orta Boylu Şabb-1 Hüseyin Ağa oğlu 16 Mehmed Emred Molla Mehmed Ali Efendi bin Süleyman

Çömezi

Orta Boylu Hacı Hasan oğlu 20

Müzellef Sakallı Molla Ali bin Hasan

Orta Boylu Ter Bekir oğlu Molla 19

Biyıkl1 Ahmed bin Bekir

Orta Boylu Köse Molla Mustafa bin 25 Kumral Sakallı Ahmed

Orta Boylu Köse Molla Mustafa bin 28 Kumral Sakallı Ahmed

Uzunca Boylu Molla Abdurrahman 32 Kara Sakallı bin Mehmed

Uzun Boylu Şabb-1 Molla Mustafa bin Ali 18 Emred

${ }^{59}$ BOA, NFS.d. 3013, s. 13.

${ }^{60}$ Gürgen İlknur, XV-XVI. Yüzyıllarda Güzelhisar Kazası, Basılmamış Yüksek Lisans Tezi, Celal Bayar Üniversitesi, Sosyal Bilimler Enstitüsü, Manisa 2015, s. 19; Çiğdem Taş, a.g.e., s. 82; Abdulhalim Durma, a.g.e., s. 10. 


\section{No \\ Medresede Bulunan} Kişinin Geldiği Yer

Yakınlık

Derecesi

ve

\section{Maiyetinin}

Niteliği ve

Görevi
9 Koçak Nahiyesinden gelmiştir Sene 58 Kuyucular Karyeli

10 Balad Abad Kazasından gelmiştir Sene 58 Bağaras1 Karyeli

11 Balad Abad Kazasından gelmiştir Sene 57 Bağarası Karyeli

12 Çine abad Kazasıdan gelmiştir Sene 55 Kırk 1ş1klı Karyeli

13 Çine abad Kazasıdan gelmiștir Sene 59 Çaltı karyeli
14 Çine abad Kazasıdan gelmiştir Sene 59 Kırk 1şıklı Karyeli

15 Çine abad Kazasıdan gelmiştir Sene 59 Çaltı karyeli

\section{Fiziksel Özellikleri}

Ya

Ş

Orta Boylu Şabb-1 Molla Mustafa bin 18

Emred Hüseyin

Uzunca Boylu Ter Molla Halil bin Hac1 22

Biyıklı Mehmed

Orta Boylu Ter Molla Mustafa bin 20

Biylklı Mehmed

Orta Boylu Molla Halil bin 28

Müzellef Sarı Mehmed

Sakallı

Orta Boylu Şabb-1 Molla Ali bin 18

Emred Mehmed

Orta Boylu Şabb-1 Molla İbrahim bin 18 Emred İsmail

Orta Boylu Şabb-1 Molla Mustafa bin Ali 15 Emred

\section{Çarıkçızade Medresesi ${ }^{61}$}

Cuma Mahallesi'nde bulunan Çarıklıŏlu Medresesi, Çarıkçızade Hacı Mehmet Ağa tarafından yaptırılmıştır. Medresenin müderrisi Hasan Efendi’nin 1898 ve 1899 yıllarında talebe say1s1 sekizdir. ${ }^{62}$

Defterimizde 6 kișinin kaydı bulunmaktadır. 15 ile 28 yaş aralığına sahip bu kișilerin ortalama yaş seviyesi 21,5'dur. Fiziksel özellik olarak da "Orta Boylu" ve "Sakallı" özellikleri göstermektedirler.

"Mustafa" ismi ağırlıkta olup, "Molla" öneki ile birlikte kullanılmaktadır.

${ }^{61}$ BOA, NFS.d. 3013, s. 13-14.

${ }^{62}$ Çiğdem Taş, a.g.t., s. 80; Abdulhalim Durma, a.g.e., s. 44. 


\section{No Medresede Bulunan Kişinin Geldiği Yer}

1 Arpaz Kazasindan gelmiştir Sene 45 Köte Karyeli $^{63}$

2 Arpaz Kazasından Karındaşı gelmiştir Sene 45

3 Karahayıt Kazasindan gelmiştir Sene 57 Kasar Karyeli

4 Karahayıt Kazasindan gelmiştir Sene 57 Kasar Karyeli

5 Çine abad Kazasından gelmiştir Sene 57 Çaltı Karyeli

6 Şahme Kazasından gelmiştir Sene 59 Sarban dereli

\section{Yakınlık \\ Derecesi ve \\ Maiyetinin \\ Niteliği ve}

Görevi

Orta Boylu Kumral Molla Osman bin 25 Biyıklı

İbrahim

$\begin{array}{llll}\text { Orta Boylu Ter Molla Mustafa } & 19\end{array}$

Biyıklı

Orta Boylu Kara Nalband oğlu Molla 26

Sakallı Mustafa bin Hac1 Mustafa

Orta Boylu Şabb-1 Hac1 İmam oğlu 16

Emred Molla Ali bin Hac1

Ali

Orta Boylu Şabb-1 Molla Hüseyin oğlu 15

Emred

Molla Mehmed bin

Halil

Uzun Boylu Taze Tosun oğlu Molla 28

Kumral Sakallı
Abdurrahman bin

Mehmed

\section{Hacı Suhtezade Medresesi ${ }^{64}$}

Yağlı Mahallesi'nde bulunan Hacı Suhteoğlu Medresesi'ni, Hacı Suhtezade yaptırmıştır. Yüzyıl başlarında Aydınlı Mustafa Efendi'nin müderrisliğini yaptı̆̆ı medresede 1898 ve 1899 yıllarında talebe sayıs1 17'dir. 1900'de Müderris Mustafa Efendi'nin 22 talebesi bulunurken, 1901 ve 1903 y1llarında medresede 27 talebe eğitim görmektedir. ${ }^{65}$

Defterde üç kişinin kaydı bulunmaktadır. 16 ile 38 yaş aralığına sahip bu kişilerin ortalama yaş seviyesi 28'dir. Fiziksel özellik olarak da "Orta Boylu" ve "Sakallı" özellikleri göstermektedirler.

"Mehmed" ismi ağırlıkta olup, "Molla" öneki ile birlikte kullanılmaktadır.

No Medresede Bulunan

Kişinin Geldiği Yer

1 Teke Kazasina tabi ... Karyesinden gelmiştir Sene 52

2 Karpuzlu Kazasına tabi Çömezi Çobanisa Karyesinden gelmiştir Sene 59

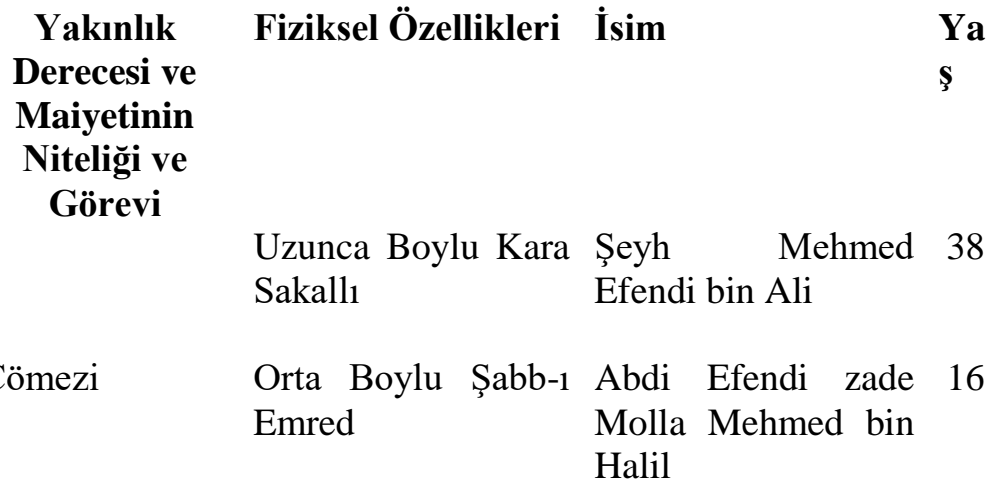

${ }^{63}$ Yenice, Aydın İli’nin Bozdoğan İlçesi’ne bağlı bir köydür. Yenice Köyü’nün eski adı Köte idi. 1955 ’te Yenice olarak değiştirilmiştir.

${ }^{64}$ BOA, NFS.d. 3013, s. 14.

${ }^{65}$ Çiğdem Taş, a.g.t., s. 80; Abdulhalim Durma, a.g.e., s. 45. 


\section{No Medresede Bulunan Kişinin Geldiği Yer \\ 3 Burdur Kazasina tabi Gölhisar Kazasindan gelmiştir Sene 50}

\section{Yakınlık \\ Derecesi ve \\ Maiyetinin \\ Niteliği ve \\ Görevi}

\section{Cincinlizade Medresesi ${ }^{66}$}

Cuma Mahallesi'nde bulunan Cincinoğlu Medresesini Cincinoğlu yaptırmıştır. Medresenin müderrisi Hüsnü Efendi zamanında üç talebesi bulunurken 1899 yılına ait salnamede bu say1 dokuza yükselmiştir. 1900 yılında üç talebesi bulunan medresenin 1901 ve 1903 yıllarında dokuz talebe eğitim görmektedir. ${ }^{67}$

Defterde 10 kişinin kaydı bulunmaktadır. Sekiz ile 56 yaş aralığına sahip bu kişilerin ortalama yaş seviyesi 21 'dir. Fiziksel özellik olarak da "Orta Boylu” ve "Sakalll” özellikleri göstermektedirler.

"Mustafa" ismi ağırlıkta olup, "Molla" öneki ile birlikte kullanılmaktadır.

\section{4}

$10 / 2$

April

2020
No

Medresede Bulunan
Kișinin Geldiği Yer
1 Mandalyad Kazasına tabi Derince Karyesinden gelmiştir Sene 55

2 Mandalyad Kazasına tabi Derince Karyesinden gelmiştir Sene 59

3 Mandalyad Kazasına tabi Derince Karyesinden gelmiştir Sene 59

4 Mandalyad Kazasına tabi Derince Karyesinden gelmiştir Sene 58

5 Mandalyad Kazasına tabi Derince Karyesinden gelmiştir Sene 58

6 Kuşadası canibinden gelmiştir Sene 59

7 Kuşadası canibinden gelmiştir Sene 59

Yakın
Dereces
ve
Maiyeti
Niteliği
Göre
Çömezi

\section{Fiziksel \\ Özellikleri}

İsim Ya ş
Orta Boylu Kumral Mehmed Hoca oğlu 28

Sakallı Mustafa Efendi bin Mehmed

Orta Boylu Şabb-1 Hacı Camusçu oğlu 15 Emred Molla Mustafa bin Mustafa

Orta Boylu Ter Camusçu oğlu Molla 18 Biyıklı Mustafa bin Mehmed

Orta Boylu Ter Hacı Karaca oğlu 18 Bıyıklı Molla Mehmed bin Mehmed

Orta Boylu Ter Kürt oğlu Molla 19 Bıyıklı Hüseyin bin Mehmed

Orta Boylu Hatib oğlu Molla 18 Müzellef Sakallı Ahmed bin Mehmed Kısa Boylu Ter Hacı İmam oğlu 17 Biylklı Molla Hüseyin bin Mustafa

${ }^{66}$ BOA, NFS.d. 3013, s. 14

${ }^{67}$ Çiğdem Taş, a.g.t., s. 80; Abdulhalim Durma, a.g.e., s. 44. 


\begin{tabular}{|c|c|c|c|c|c|}
\hline No & $\begin{array}{l}\text { Medresede Bulunan } \\
\text { Kişinin Geldiği Yer }\end{array}$ & $\begin{array}{c}\text { Yakınlık } \\
\text { Derecesi } \\
\text { ve } \\
\text { Maiyetinin } \\
\text { Niteliği ve } \\
\text { Görevi }\end{array}$ & $\begin{array}{l}\text { Fiziksel } \\
\text { Özellikleri }\end{array}$ & İsim & $\begin{array}{c}\text { Ya } \\
\text { ş }\end{array}$ \\
\hline 1 & $\begin{array}{l}\text { Mandalyad Kazasına tabi } \\
\text { Derince Karyesinden } \\
\text { gelmiştir Sene } 55\end{array}$ & & $\begin{array}{l}\text { Orta Boylu Kumral } \\
\text { Sakallı }\end{array}$ & $\begin{array}{l}\text { Mehmed Hoca oğlu } \\
\text { Mustafa Efendi bin } \\
\text { Mehmed }\end{array}$ & 28 \\
\hline 8 & $\begin{array}{l}\text { Kuşadas1 canibinden } \\
\text { gelmiştir Sene } 60\end{array}$ & & $\begin{array}{l}\text { Uzunca Boylu Ter } \\
\text { Biyıklı }\end{array}$ & $\begin{array}{l}\text { Dereli Hüseyin oğlu } \\
\text { Molla Mehmed bin } \\
\text { Hüseyin }\end{array}$ & 17 \\
\hline 9 & $\begin{array}{l}\text { Mandalyad } \quad \text { Kazasından } \\
\text { gelmiștir Sene } 59\end{array}$ & & $\begin{array}{l}\text { Orta Boylu Ak } \\
\text { Sakall }\end{array}$ & $\begin{array}{l}\text { Molla Ahmed bin } \\
\text { Mehmed }\end{array}$ & 56 \\
\hline 10 & $\begin{array}{l}\text { Mandalyad Kazasından } \\
\text { gelmiştir Sene } 59\end{array}$ & Oğlu & & Molla Ali & 8 \\
\hline
\end{tabular}

\section{Çilingirzade Medresesi ${ }^{68}$}

Defterde iki kişinin kaydı bulunmaktadır. 40 ile 50 yaş aralığına sahip bu kişilerin ortalama yaş seviyesi 45'dir. Fiziksel özellik olarak da "Orta Boylu" ve "Sakallı" özellikleri göstermektedirler.

"Mustafa ve Osman" isimlerine sahip olunup, "Efendi ve Hacl” öneki ile birlikte kullanılmaktadır.

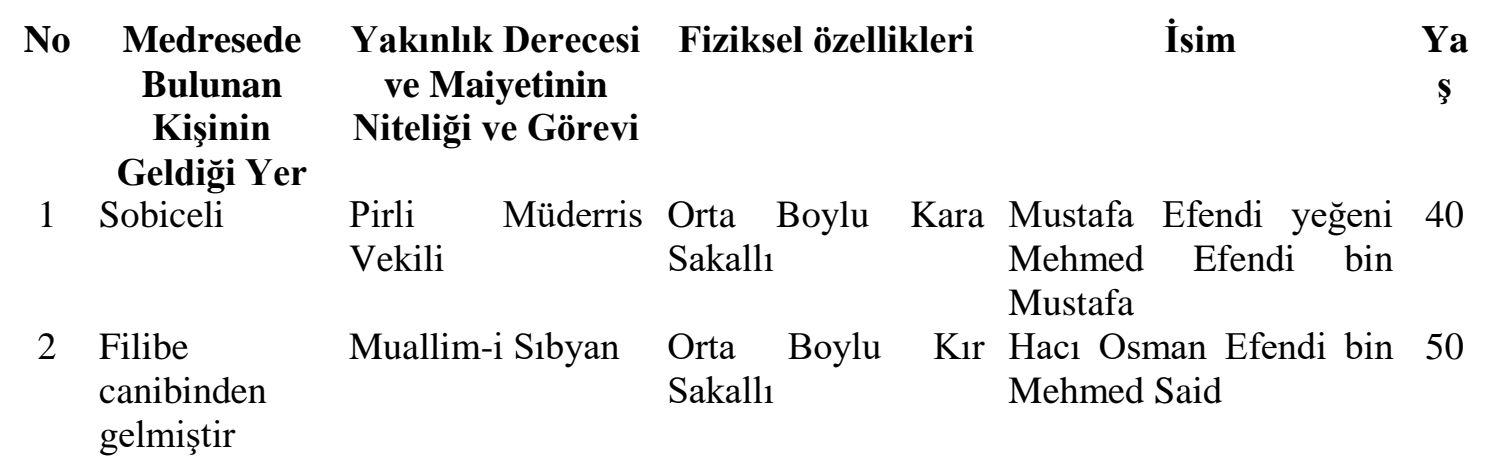

\section{Ali Hoca Medresesi ${ }^{69}$}

Defterde beş kişinin kaydı bulunmaktadır. Dokuz ile 58 yaş aralığına sahip bu kişilerin ortalama yaş seviyesi 27'dir. Fiziksel özellik olarak da "Orta Boylu” ve "Sakalll” özellikleri göstermektedirler.

"Mehmed" ismi ağırlıkta olup, "Molla" öneki ile birlikte, isimlerden sonra "Efendi" de sonek olarak kullanılmaktadır.

\footnotetext{
${ }^{68}$ BOA, NFS.d. 3013, s. 14.

${ }^{69}$ BOA, NFS.d. 3013, s. 15 .
} 


\begin{tabular}{|c|c|c|c|c|c|}
\hline No & $\begin{array}{l}\text { Medresede Bulunan } \\
\text { Kişinin Geldiği Yer }\end{array}$ & $\begin{array}{c}\text { Yakınlık } \\
\text { Derecesi } \\
\text { ve } \\
\text { Maiyetinin } \\
\text { Niteliği ve } \\
\text { Görevi }\end{array}$ & $\begin{array}{l}\text { Fiziksel } \\
\text { Özellikleri }\end{array}$ & İsim & Yaş \\
\hline 1 & $\begin{array}{l}\text { Yenipazar Kazasından } \\
\text { gelmiştir sene } 41\end{array}$ & & $\begin{array}{l}\text { Orta Boylu } \\
\text { Kır Sakallı }\end{array}$ & $\begin{array}{l}\text { Molla İbrahim bin } \\
\text { Hasan }\end{array}$ & 58 \\
\hline 2 & $\begin{array}{l}\text { Karahayit Kazasına tabi } \\
\text { Armud karyesinden } \\
\text { gelmiştir sene } 57\end{array}$ & Çömezi & $\begin{array}{l}\text { Uzunca } \\
\text { Boylu } \\
\text { Ter Blyıkl1 }\end{array}$ & $\begin{array}{l}\text { Kör Hasan oğlu Molla } \\
\text { Ali bin Hasan }\end{array}$ & 18 \\
\hline 3 & $\begin{array}{l}\text { Karahayit Kazasına tabi } \\
\text { Armud karyesinden } \\
\text { gelmiştir sene } 57\end{array}$ & Çömezi & & $\begin{array}{l}\text { Pehlivan oğlu Molla } \\
\text { Süleyman bin Hüseyin }\end{array}$ & 12 \\
\hline 4 & $\begin{array}{l}\text { Karahayit Kazasına tabi } \\
\text { Armud karyesinden } \\
\text { gelmiştir sene } 57\end{array}$ & Çömezi & & $\begin{array}{l}\text { Molla Mustafa oğlu } \\
\text { Mehmed bin Mustafa }\end{array}$ & 9 \\
\hline 5 & $\begin{array}{l}\text { Konya'ya tabi Bozkır } \\
\text { Kazasından gelmiştir sene } \\
48\end{array}$ & Merkebçi & $\begin{array}{l}\text { Orta Boylu } \\
\text { Kara Sakallı }\end{array}$ & $\begin{array}{l}\text { Mehmed Efendi bin } \\
\text { Mehmed }\end{array}$ & 38 \\
\hline
\end{tabular}

\section{İhtisab Medresesi ${ }^{70}$}

Defterde altı kişinin kaydı bulunmaktadır. 12 ile 60 yaş aralığına sahip bu kişilerin ortalama yaş seviyesi 29'dur. Fiziksel özellik olarak da "Orta Boylu" ve "Sakall" özellikleri göstermektedirler.

"Mehmed" ismi ağırlıkta olup, "Molla" öneki ile birlikte, isimlerden sonra "Efendi" de sonek olarak kullanılmaktadır.

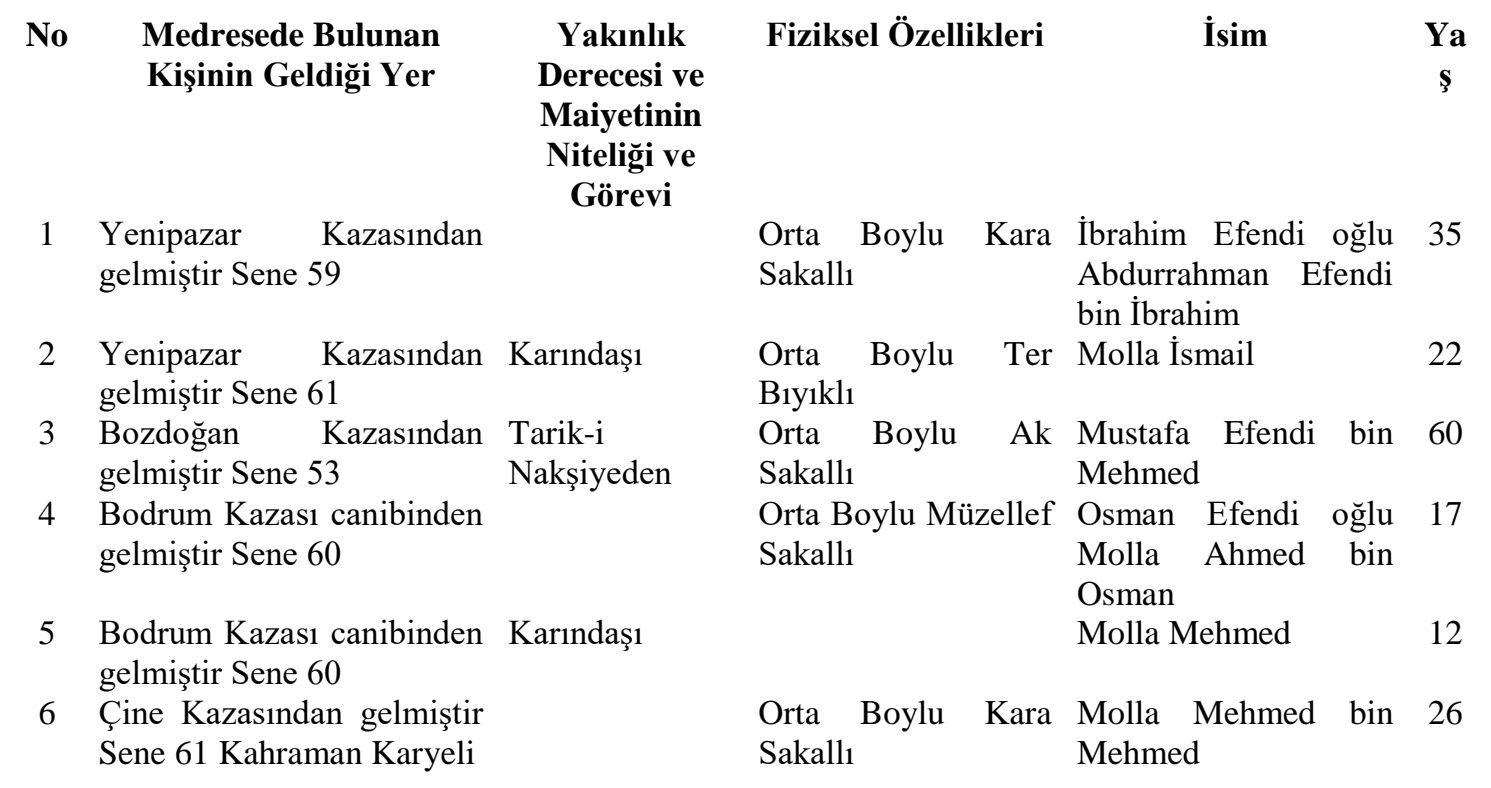

\footnotetext{
${ }^{70}$ BOA, NFS.d. 3013, s. 15.
} 


\section{Yağır oğlu Medresesi ${ }^{71}$}

Defterde altı kişinin kaydı bulunmaktadır. Dokuz ile 28 yaş aralığına sahip bu kişilerin ortalama yaş seviyesi 19'dur. Fiziksel özellik olarak da "Orta Boylu” ve "Sakallı" özellikleri göstermektedirler.

"Ali" ismi ağırlıkta olup, "Molla" öneki ile birlikte, isimlerden sonra "Efendi" de sonek olarak kullanılmaktadır.

\begin{tabular}{|c|c|c|c|c|}
\hline No & $\begin{array}{l}\text { Medresede Bulunan } \\
\text { Kişinin Geldiği Yer }\end{array}$ & $\begin{array}{c}\text { Yakınlık } \\
\text { Derecesi ve } \\
\text { Maiyetinin } \\
\text { Niteliği ve } \\
\text { Görevi }\end{array}$ & $\begin{array}{c}\text { Fiziksel } \\
\text { özellikleri }\end{array}$ & İsim \\
\hline 1 & $\begin{array}{l}\text { Bozdoğan Kazasina tabi ... } \\
\text { gelmistir Sene } 50\end{array}$ & Müderris & $\begin{array}{l}\text { Orta Boylu } \\
\text { Kumral Sakallı }\end{array}$ & $\begin{array}{l}\text { Mehmed Efendi bin } \\
\text { Mustafa }\end{array}$ \\
\hline 2 & & Çömezi & & $\begin{array}{l}\text { Hacı SSeyh oğlu Molla } \\
\text { Ali bin Mehmed }\end{array}$ \\
\hline 3 & $\begin{array}{l}\text { Koçak Kazasına tabi Eğri } \\
\text { kavak Karyesinden } \\
\text { gelmiştir Sene } 58\end{array}$ & & $\begin{array}{l}\text { Orta Boylu } \\
\text { Taze Kara } \\
\text { Sakallı }\end{array}$ & $\begin{array}{l}\text { Hacı İmam oğlu } \\
\text { Molla Ali bin } \\
\text { Mehmed }\end{array}$ \\
\hline 4 & & & $\begin{array}{l}\text { Orta Boylu } \\
\text { Müzellef Sakallı }\end{array}$ & $\begin{array}{l}\text { Pirli Nalband oğlu } \\
\text { Molla Ahmed bin } \\
\text { Hac1 Mehmed }\end{array}$ \\
\hline 5 & $\begin{array}{l}\text { Sobice Kazasına tabi } \\
\text { Çakırbeyli Karyesinden } \\
\text { gelmiştir Sene } 58\end{array}$ & & $\begin{array}{l}\text { Uzunca Boylu } \\
\text { Ter Biyıklı }\end{array}$ & $\begin{array}{l}\text { Ahmed oğlu Molla } \\
\text { İbrahim bin Ahmed }\end{array}$ \\
\hline 6 & $\begin{array}{l}\text { Sobice Kazasına tabi } \\
\text { Çakırbeyli Karyesinden } \\
\text { gelmiştir Sene } 58\end{array}$ & & $\begin{array}{l}\text { Orta Boylu } \\
\text { Ter Biyıklı }\end{array}$ & $\begin{array}{l}\text { Arab oğlan oğlu } \\
\text { Molla Salih bin } \\
\text { Mustafa }\end{array}$ \\
\hline
\end{tabular}

Ya

Defterde altı kişinin kaydı bulunmaktadır. Dokuz ile 55 yaş aralığına sahip bu kişilerin ortalama yaş seviyesi 28'dir. Fiziksel özellik olarak da "Orta ve Uzun Boylu" ve "Sakallı" özellikleri göstermektedirler.

"Ahmed" ismi ağırlıkta olup, "Molla ve Hacl” öneki ile birlikte, isimlerden sonra "Efendi" de sonek olarak kullanılmaktadır.

\section{No Medresede Bulunan Kişinin Geldiği Yer \\ 1 Çine Kazasından gelmiştir Sene 59 Soğancılar Karyeli \\ 2 Karahayıt Kazasina tabi Kasar Karyesinden gelmiştir Sene 56}

\begin{tabular}{cllc}
$\begin{array}{c}\text { Yakınlık } \\
\text { Derecesi ve } \\
\text { Maiyetinin } \\
\text { Niteliği ve } \\
\text { Görevi }\end{array}$ & \multicolumn{1}{c}{$\begin{array}{c}\text { Fiziksel } \\
\text { özellikleri }\end{array}$} & \multicolumn{1}{c}{ İsim } & $\begin{array}{c}\text { Ya } \\
\text { ş }\end{array}$ \\
& & & \\
& Uzun Boylu & $\begin{array}{l}\text { Molla İbrahim bin } \\
\text { Kara Sakallı }\end{array}$ & İbrahim \\
& Uzun Boylu & Sarı Yusuf oğlu 28 \\
& Kumral Sakallı & $\begin{array}{l}\text { Yusuf Efendi bin } \\
\text { Yusuf }\end{array}$ &
\end{tabular}

\footnotetext{
${ }^{71}$ BOA, NFS.d. 3013, s. 15.

${ }^{72}$ BOA, NFS.d. 3013, s. 15-16.
} 


\section{No Medresede Bulunan Kişinin Geldiği Yer}

\section{Yakınlık \\ Derecesi ve \\ Maiyetinin \\ Niteliği ve \\ Görevi}

3 Karahayıt Kazasına tabi Çömezi

Kasar Karyesinden

gelmiştir Sene 58

4 Karahayıt Kazasına tabi Çömezi

Kasar Karyesinden

gelmiştir Sene 59

5 Karahayitlı

6
Fiziksel

özellikleri
Ya

ş
Orta Boylu

Kumral Sakallı

Orta Boylu

Köse Kır Sakallı
Çulha oğlu 11

Mehmed bin Ali

Kethüda oğlu 9

Molla Salih bin

Mehmed

Ahmed Efendi bin 35

Mehmed Efendi

Pirli Hac1 Molla 55

Ahmed bin

Mehmed

\section{Posacıoğlu Medresesi ${ }^{73}$}

Posacızade Hacı Mustafa Ağa tarafından yaptırılan medrese Köprülü Mahallesi’nde bulunmaktadır. 1898 ve 1899 yıllarına ait Maarif Salnamesi'ne göre bu yıllarda medresenin müderrisi olan Ali Efendi zamanında medresede sekiz talebe eğitim görmektedir. Müderris Hacı Mehmet Ağa'nın vazife yaptığ 1900 yılında 13 talebe bulunmaktadır. 1901 ve 1903 yıllarında talebe sayısı 18 iken müderris olarak ise Hacı Mehmet Ağa vazifeye devam etmektedir.

Bunun dışında Terziler Mahallesi'nde de Posacızade Hacı Mustafa Ağa tarafından yaptırılan aynı adla bir medrese daha bulunmaktadır. 1898 ve 1899 yıllarında medresenin müderrisi Çineli Ahmet Efendi' dir. Ahmet Efendi'nin 1898 yılındaki müderrisliği sırasında talebe sayıs 30 iken, 1900, 1901 ve 1903'te yine Ahmet Efendi'nin 38 talebesi bulunmaktadır. ${ }^{74}$

Defterde yedi kişinin kaydı bulunmaktadır. 22 ile 43 yaş aralığına sahip bu kişilerin ortalama yaş seviyesi 29'dur. Fiziksel özellik olarak da "Orta Boylu” ve "Sakallı" özellikleri göstermektedirler.

"Mustafa" ismi ağırlıkta olup, "Molla ve Hacl" öneki ile birlikte, isimlerden sonra "Efendi" de sonek olarak kullanılmaktadır.

\begin{tabular}{|c|c|c|c|c|}
\hline No & $\begin{array}{l}\text { Medresede Bulunan } \\
\text { Kișinin Geldiği Yer }\end{array}$ & Fiziksel Özellikleri & İsim & $\begin{array}{c}\text { Ya } \\
\mathbf{s}\end{array}$ \\
\hline 1 & Umurlu Karyeli & $\begin{array}{l}\text { Orta Boylu } \\
\text { Sakallı }\end{array}$ & $\begin{array}{l}\text { Mühtedi Molla Mustafa bin } \\
\text { Abdullah }\end{array}$ & 28 \\
\hline 2 & $\begin{array}{l}\text { Karahayit Kazasindan } \\
\text { gelmistir Sene } 54\end{array}$ & $\begin{array}{l}\text { Orta Boylu Müzellef } \\
\text { Kara Sakallı }\end{array}$ & $\begin{array}{l}\text { Molla Mehmed bin Karagöz } \\
\text { Mehmed }\end{array}$ & 23 \\
\hline 3 & & $\begin{array}{l}\text { Orta Boylu Kumral } \\
\text { sakallı }\end{array}$ & Pirli Molla Halil bin Mustafa & 39 \\
\hline 4 & $\begin{array}{l}\text { Atça Kazasından gelmiştir } \\
\text { Sene } 52 \text { Dereköylü }\end{array}$ & $\begin{array}{l}\text { Orta Boylu } \\
\text { Sakallı }\end{array}$ & Hafiz Mustafa bin Hacı Mustafa & 25 \\
\hline 5 & & $\begin{array}{l}\text { Orta Boylu Kırca } \\
\text { Kara Sakallı }\end{array}$ & $\begin{array}{l}\text { Pirli Hafiz Hasan Efendi bin } \\
\text { Ahmed }\end{array}$ & 43 \\
\hline
\end{tabular}

\footnotetext{
${ }^{73}$ BOA, NFS.d. 3013, s. 16.

${ }^{74}$ Çiğdem Taş, a.g.t., s. 76-77; Abdulhalim Durma, a.g.e., s. 40-41.
} 


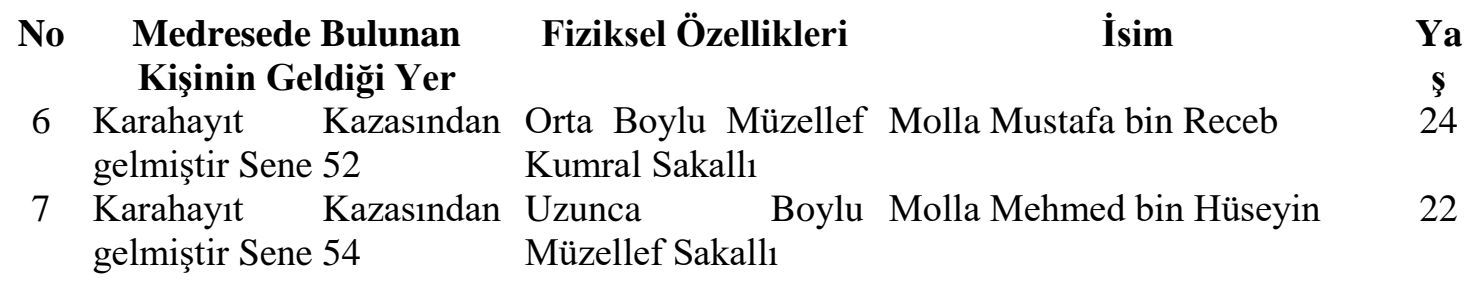

\section{Dükkanönü Medresesi ${ }^{75}$}

Dükkanönü Medresesi, Cuma Mahallesi'ndeki medreselerden biridir. Taceddin Efendi tarafından yaptırıldığı bilinen medresenin müderrisi Sarayköylü Mustafa Efendi'nin 1898 ve 1899 yıllarında talebe sayısı 42'dir. 1900, 1901 ve 1903 yıllarında bu sayı 45'e ulaşır. ${ }^{76}$

Defterde dokuz kişinin kaydı bulunmaktadır. 17 ile 60 yaş aralığına sahip bu kişilerin ortalama yaş seviyesi 29'dur. Fiziksel özellik olarak da "Orta Boylu" ve "Sakallı" özellikleri göstermektedirler.

"Mehmed" ismi ağırlıkta olup, "Molla ve Hacl” öneki ile birlikte, isimlerden sonra "Efendi" de sonek olarak kullanılmaktadır.
No
Medresede
Bulunan Kişinin Geldiği Yer

1

2 Aydın'a tabi

Umurlu

Karyesinden

gelmiş̧ir Sene 45

3

4

5 Şahme Kazasından Çömezi gelmiş̧ir Sene 53

6 Sobice Kazasina tabi Haydarl

Karyesinden gelmiş̧tir Sene 54

7

8

9 hatibi

Yakınlık
Derecesi ve
Maiyetinin
Niteliği ve
Görevi

Fiziksel Özellikleri

İsim Ya s

Orta Boylu Kumral Pirli Molla Mehmed bin 25 Sakallı

Orta Boylu Kumral Molla Ahmed bin 35

Sakallı

Abdullah

Uzunca Boylu Ter Pirli Arpacı Ahmed oğlu 20

Bıyıklı Molla Kadir bin Ahmed

Uzunca Boylu Pirli Hac1 Veli zade 25

Kumral Sakallı Mehmed Efendi bin

Hasan

Orta Boylu Ter Sarı Ömer oğlu Molla 17

Biyıklı Mustafa bin Ömer

Kısa Boylu Köse Emir Ali oğlu Molla 19

Ter Biyıklı Mehmed bin Ahmed

Ba-berat-1 alişan Orta Boylu Kumral Pirli Hacı İbrahim oğlu 40 cami-i şerif Sakallı Hafız Mehmed Efendi bin Hac1 İbrahim

Orta Boylu Ak Pirli Hacı zade Ahmed 60 Sakallı Efendi bin Hacı Veli Efendi

Orta Boylu Şabb-1 Pirli Molla Ali bin Hasan 18 Emred

\footnotetext{
${ }^{75}$ BOA, NFS.d. 3013, s. 16.

${ }^{76}$ Çiğdem Taş, a.g.t., s. 79; Abdulhalim Durma, a.g.e., s. 44.
} 


\section{Zincirli nam-ı diğer Yarbaşı Medresesi ${ }^{77}$}

Yarbaşı Mahallesi'nde bulunan Zincirli Medrese iane ile yaptırılmıştır. 1898 yılına ait verilere göre Müderris Mustafa Efendi'nin 18 talebesi bulunurken, 1899 ve 1900 yıllarında 21, 1901 ve 1903 y1llarında ise 28 talebenin olduğu görülmektedir. ${ }^{78}$

Defterde 14 kişinin kaydı bulunmaktadır. Sekiz ile 25 yaş aralığına sahip bu kişilerin ortalama yaş seviyesi 17'dir. Fiziksel özellik olarak da "Orta ve Uzun Boylu" ve "Sakallı" özellikleri göstermektedirler.

"Mehmed, Mustafa ve Ali" ismi ağırlıkta olup, "Molla ve Hafiz" öneki ile birlikte, isimlerden sonra "Efendi" de sonek olarak kullanılmaktadır.

\section{No Medresede Bulunan Kişinin Geldiği Yer}

2 Aydın'a tabi Kuyucak Karyesinden gelmiş Sene 55

3 Köşk Kazassına tabi Musluca Karyesinden gelmiştir Sene 55

4 Kuyucak Nahiyesine tabi Bey Karyesinden gelmiştir Sene 54

5 Kuyucak Nahiyesine tabi Bey Karyesinden gelmiştir Sene 54

6 Kuyucak Nahiyesine tabi Bey Karyesinden gelmiştir Sene 52

7 Kuyucak Nahiyesine tabi Yeğeni Bey Karyesinden gelmiştir Sene 52

8 Davliye Çiftliğinden Çömezi gelmiştir Sene 53

9 Kuyucak Nahiyesine tabi Çömezi Bey Karyesinden gelmiştir Sene 53

10 Kuyucak Nahiyesine tabi Çömezi Bey Karyesinden gelmiştir Sene 53

\section{Yakınlık \\ Derecesi ve \\ Maiyetinin \\ Niteliği ve \\ Görevi}

İsim Ya

ş

Uzun Boylu Pirli Hafiz İsa bin 22

Köse Kara Veliüddin

Sakall1

Orta Boylu Kosto oğlu Molla 19

Müzellef

Sakallı

Orta Boylu Sarı Hoca oğlu Ali bin 16

Şabb-1 Emred Mehmed Efendi

Uzun Boylu Karagöz oğlu Molla 17

Ter Biyıklı Mustafa bin Mehmed

Uzunca Boylu Molla Veli oğlu Molla 18

Ter Bıyıklı Ali bin Mehmed

Uzunca Boylu Halil Usta oğlu Ali 25

Kara Sakallı Efendi bin Halil

Pabuççu oğlu 9

Mehmed bin Mehmed

Uzunca Boylu Tüysüz Nalband oğlu 20

Molla Osman bin

İsmail

Orta Boylu Zeybek Hoca oğlu 14

Şabb-1 Emred Molla Hasan Hüseyin

bin Mustafa

Ahmed oğlu Molla 12

Mehmed bin Ahmed

\footnotetext{
${ }^{77}$ BOA, NFS.d. 3013, s. 17.

${ }^{78}$ Çiğdem Taş, a.g.t., s. 81, Abdulhalim Durma, a.g.e., s. 45-46.
} 


\section{No Medresede Bulunan Kişinin Geldiği Yer}

11 Çine abad Kazasından gelmiştir Sene 58 Sarı oluk (Sarı Oğlan) Karyeli

12 Çine abad Kazasından Çömezi gelmiştir Sene 58

13 Çine Kazasına tabi Kavşid Karyesinden gelmiştir Sene 57

14 Çine Kazasına tabi Yeğeni Kavşid Karyesinden gelmiştir Sene 59

\section{Eş-şeyh Mevlevii ${ }^{79}$}

Yakınlık
Derecesi ve
Maiyetinin
Niteliği ve
Görevi

Fiziksel
Özellikleri

İsim

Ya

ş

$\begin{array}{llll}\text { Orta Boylu } & \text { Molla Ahmed oğlu } & 25 \\ \text { Kumral Sakallı } & \begin{array}{l}\text { Molla Mustafa bin } \\ \text { Ahmed }\end{array} & \\ \text { Orta Boylu } & \text { Mehmed oğlu Molla } & 17 \\ \text { Ter Biyıklı } & \begin{array}{l}\text { Mehmed bin Osman } \\ \text { Uzunca Boylu }\end{array} & \text { Hacı İmam oğlu } & 20 \\ \text { Köse Kara } & \text { Molla Ali bin İsmail } & \\ \text { Sakallı } & & \text { Musa bin Koca } & 8 \\ & \text { Mehmed }\end{array}$

25 17 0

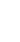

\section{No Kişinin Geldiği Yer}

\section{Yakınlık Derecesi ve Maiyetinin Niteliği ve \\ Görevi}

1 Konya canibinden gelmiştir Sene 61

2 Konya canibinden Müridi gelmiştir Sene 61

\author{
Fiziksel Özellikleri
}

İsim Ya ş

Orta Boylu Kumral Şeyh Mehmed Said 30 Sakallı Efendi bin hafiz Hüseyin

Uzunca Boylu Kara Derviş Ali bin Hasan 25

\section{Han, Kahvehane, Dükkân ve Çeşitli Köylerde Kalan Bekâr Nüfus}

Aydın ve Aydın'a bağlı yerleşim yerlerinde birçok bekâr nüfus kalmaktaydı. Bu gelen kişiler Balcı oğlu Hanı, Cihanzade Hanı, Deliler Hanı, Hacı Ali Efendi Hanı, Hacı Mustafa Efendi Hanı, İnce Bayraktar Han, Köprübaşı Hanı, Kör Keçiler Han1, Körük = Gödek Hanı, Kurşunlu Han, Mimar Han, Mustafa Paşa Hanı, Osmanzade Hanı, Şamlı oğlu Hanı, Yakup Paşa Hanı ve Muytab Hanı gibi yerlerde kalırken, aynı zamanda Tekke Odası, Kahvehane ve dükkânlarda ya da çevre köylerde konaklamaktaydılar.

$\mathrm{Bu}$ gelen kişiler ya iş için gelip yerleşmekteler ya da perakende yani gelip geçici olarak iş peşinde koşmak için gelmekteydiler.

İş için ya da kervanlarla gelip geçici olarak gelenler han ve yukarıda belirttiğimiz yerlere gelerek alış veriş, takas yaparlar veya mesleklerini Aydın ve çevresinde icra etmek için gelip yerleşirler ya da kervanlarıyla tekrar yola koyulurlardı.

1830'larda bölgede seyahat eden Arundell "halk kervansarayı" olarak nitelediği hanları, "mobilyasız ve aynı odanın içinde tek gözlü barınaklar" şeklinde tarif eder. Bu hanlarda yolcular içeride uyurken develer ve deveciler de hanın dişında açık havada uyurlardı. Hanlarda mallar,

\footnotetext{
${ }^{79}$ BOA, NFS.d. 3013, s. 17.
} 
hana gelen perakendeci tüccarlara verilir ve hatta bazen üreticiler doğrudan, tüketicilere mallarını satabilirlerdi, zaman zaman kahvehaneler de bu rolü üstlenebiliyorlard1. ${ }^{80}$

Han, kahvehane ve dükkânlarda kalanlara baktığımızda 232 kişinin çoğunun Buldan'dan geldiği görülmektedir. Bunun yanında Kadı Karyeli 12 kişi, Yalvaşlı 11 kişi çoğunluğu oluşturmaktadır. Mısırlı, Şamlı, Rodoslu, Mekke, Asitane yani İstanbul'dan da gelip yerleşenler veya ticari faaliyet yürütenler görülmektedir.

Bu kişiler, ekmekçi, hamal, hanc1, kahveci, muytab, yemenici mesleklerini icra ederlerken, Girit ve Rodos'tan gelenler Bahçıvanlık, Buldan ve Yalvaç'tan gelenler Culha, Sarayköy ve Uluborlu'dan gelenler Helvacı, Mısır, Şam ve Mekke'den gelenler ise Şekercilik mesleğini yürütmekteydiler.

İsimlerini baktı̆̆ımız zaman;

102

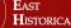

$10 / 2$

April

2020

\section{En Çok Kullanılan İsimler}

Mehmed

Ali

Mustafa

Ahmed

Hasan

İbrahim

Hüseyin

İsmail

Osman

Süleyman

\section{Sayısı}

Fiziksel Özellikleri;

$$
\begin{gathered}
\text { Orta Boylu } \\
\text { Uzunca } \\
\text { Boylu }
\end{gathered}
$$

Kisa Boylu
174

46

\footnotetext{
80 Olcay Pullukçuoğlu Yapucu, Cihan Özgün, "Batı Anadolu'nun Yol Ağı Araştırmaları III, İzmir'in Ardalanında
} Kervan Yolları", Tarih Incelemeleri Dergisi, c. XXVI, S. 2 Aralık 2011, s. 527-549. 
Hacı Mustafa Efendi Hanı ${ }^{81}$

\begin{tabular}{|c|c|c|c|c|c|c|}
\hline No & Kişinin Geldiği Yer & $\begin{array}{l}\text { Yakınlık } \\
\text { Derecesi } \\
\text { ve } \\
\text { Maiyetini } \\
\text { n Niteliği } \\
\text { ve Görevi }\end{array}$ & Mesleği & $\begin{array}{l}\text { Fiziksel } \\
\text { Özellikleri }\end{array}$ & İsim & $\begin{array}{c}\mathbf{Y a} \\
\mathbf{s}\end{array}$ \\
\hline 1 & $\begin{array}{l}\text { Karacasu Kazasından } \\
\text { gelmiştir Sene } 60\end{array}$ & & $\begin{array}{l}\text { Çulha } \\
\text { Esnafi }\end{array}$ & $\begin{array}{l}\text { Orta Boylu } \\
\text { Kara Sakallı }\end{array}$ & $\begin{array}{l}\text { Yolcu oğlu Osman } \\
\text { bin Mehmed }\end{array}$ & 30 \\
\hline 2 & $\begin{array}{l}\text { Isparta canibinden } \\
\text { gelmiştir Sene } 56 \\
\text { Eğirdir Kazasından }\end{array}$ & & $\begin{array}{l}\text { Çulha } \\
\text { Esnafi }\end{array}$ & $\begin{array}{l}\text { Orta Boylu } \\
\text { Kumral } \\
\text { Biyıklı }\end{array}$ & $\begin{array}{l}\text { Topal Hasan oğlu } \\
\text { Musa bin Ahmed }\end{array}$ & 25 \\
\hline 3 & $\begin{array}{l}\text { Alaşehir Kazasından } \\
\text { gelmiştir Sene } 50 \\
\text { Alemşahlı Karyeli }\end{array}$ & & $\begin{array}{l}\text { Çulha } \\
\text { Esnafi }\end{array}$ & $\begin{array}{l}\text { Orta Boylu } \\
\text { Kir Biy1klı }\end{array}$ & Halil bin Mustafa & 50 \\
\hline 4 & $\begin{array}{l}\text { Denizli Kazas1 } \\
\text { canibinden gelmiştir } \\
\text { Sene } 59 \text { Kadı Karyeli }\end{array}$ & & $\begin{array}{l}\text { Çulha } \\
\text { Esnafi }\end{array}$ & $\begin{array}{l}\text { Orta Boylu } \\
\text { Kir Sakallı }\end{array}$ & $\begin{array}{l}\text { Koca Yiğit oğlu } \\
\text { Salih bin İbrahim }\end{array}$ & 63 \\
\hline 5 & $\begin{array}{l}\text { Denizli Kazası } \\
\text { canibinden gelmiştir } \\
\text { Sene } 59\end{array}$ & Oğlu & $\begin{array}{l}\text { Çulha } \\
\text { Çırağı }\end{array}$ & $\begin{array}{l}\text { Orta Boylu } \\
\text { Ter Biyıklı }\end{array}$ & Cafer & 17 \\
\hline 6 & $\begin{array}{lr}\begin{array}{l}\text { Denizli } \\
\text { canibinden }\end{array} & \begin{array}{r}\text { Kazas1 } \\
\text { gelmisstir }\end{array} \\
\text { Sene 59 Kad1 Karyeli }\end{array}$ & & $\begin{array}{l}\text { Çulha } \\
\text { Tarakçısı }\end{array}$ & $\begin{array}{l}\text { Orta Boylu } \\
\text { Kumral } \\
\text { Sakallı }\end{array}$ & $\begin{array}{l}\text { Ali Beşe oğlu } \\
\text { Mustafa bin Osman }\end{array}$ & 45 \\
\hline 7 & $\begin{array}{lr}\text { Denizli } & \text { Kazas1 } \\
\text { canibinden } & \text { gelmisstir } \\
\text { Sene 60 Kad1 Karyeli }\end{array}$ & & $\begin{array}{l}\text { Çulha } \\
\text { Esnafi }\end{array}$ & $\begin{array}{l}\text { Uzunca } \\
\text { Boylu } \\
\text { Kara Sakallı }\end{array}$ & $\begin{array}{l}\text { Osman Ağa oğlu } \\
\text { Ahmed bin Osman }\end{array}$ & 32 \\
\hline 8 & $\begin{array}{lr}\begin{array}{l}\text { Denizli } \\
\text { canibinden }\end{array} & \text { Kazas1 } \\
\text { Sene 55 } & \text { gelmiştir }\end{array}$ & & $\begin{array}{l}\text { Çulha } \\
\text { Esnafi }\end{array}$ & $\begin{array}{l}\text { Orta Boylu } \\
\text { Kir Sakallı }\end{array}$ & $\begin{array}{lr}\text { Ahmed } & \text { oğlu } \\
\text { Süleyman } & \text { bin } \\
\text { Ahmed } & \end{array}$ & 55 \\
\hline 9 & $\begin{array}{l}\text { Karacasu Kazasından } \\
\text { gelmiştir Sene } 60\end{array}$ & & $\begin{array}{l}\text { Çulha } \\
\text { Esnafi }\end{array}$ & $\begin{array}{l}\text { Kisa Boylu } \\
\text { Kumral } \\
\text { Biyıklı }\end{array}$ & $\begin{array}{lr}\text { Odabaş1 } & \text { oğlu } \\
\text { Hüseyin } & \text { bin } \\
\text { Mehmed } & \end{array}$ & 40 \\
\hline 10 & $\begin{array}{l}\text { Tavaz } \\
\text { canibinden } \\
\text { Kelmişasir } \\
\text { Sene } 60 \text { Yarangüme } \\
\text { Karyeli } \\
\text { Cihanzade Hanı }^{\mathbf{8 2}}\end{array}$ & & $\begin{array}{l}\text { Çulha } \\
\text { Esnafi }\end{array}$ & $\begin{array}{l}\text { Orta Boylu } \\
\text { Ter Kara } \\
\text { Biyıklı }\end{array}$ & $\begin{array}{l}\text { Memiş bin Kara } \\
\text { Ahmed }\end{array}$ & 18 \\
\hline 1 & $\begin{array}{l}\text { Muğla canibinden } \\
\text { gelmiştir Sene } 55\end{array}$ & & $\begin{array}{l}\text { Han } \\
\text { Odabaşıs1 }\end{array}$ & $\begin{array}{l}\text { Orta Boylu } \\
\text { Kara Biyıklı }\end{array}$ & $\begin{array}{lr}\text { Murtaza } & \text { oğlu } \\
\text { Süleyman } & \text { bin } \\
\text { İbrahim } & \end{array}$ & 25 \\
\hline 2 & $\begin{array}{l}\text { Muğla canibinden } \\
\text { gelmiştir Sene } 55\end{array}$ & Karındaşı & Kahveci & $\begin{array}{l}\text { Orta Boylu } \\
\text { Ter Biyıklı }\end{array}$ & Ahmed bin İbrahim & 19 \\
\hline 3 & $\begin{array}{l}\text { Trabzon canibinden } \\
\text { gelmiştir Sene } 60\end{array}$ & & $\begin{array}{l}\text { Çilingir } \\
\text { esnafi }\end{array}$ & $\begin{array}{l}\text { Kisa Boylu } \\
\text { Kumral } \\
\text { Biyıklı }\end{array}$ & $\begin{array}{l}\text { Ahmed Reis oğlu } \\
\text { Emin bin Ahmed }\end{array}$ & 35 \\
\hline
\end{tabular}

103

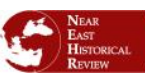

$10 / 2$

April

2020

\footnotetext{
${ }^{81}$ BOA, NFS.d. 3013, s. 18.

82 BOA, NFS.d. 3013, s. 18.
} 


\section{No Kişinin Geldiği Yer}

Yakınlık

Derecesi

ve

Maiyetini

n Niteliği

ve Görevi

$4 \quad$ Sandikl1 Kazası canibinden gelmiştir

Sene 60

5 Beyşehri canibinden gelmiştir Sene 59 Bozkır Kazasına tabi Hoca

Karyeli

6 Isparta canibinden gelmiştir Sene 59

7 Antakya canibinden gelmiştir Sene 61

8 Isparta Kazas1 canibinden gelmiştir Sene 57

9 Isparta canibinden gelmiştir Sene 57

10 Muğla canibinden gelmiştir Sene 60

11 Isparta Kazas1 canibinden gelmiştir Sene 60

12 Isparta Kazas1 canibinden gelmiştir Sene 60

13 Ödemiş Kazasından gelmiştir Sene 60

14 Tiryanda Nahiyesindne gelmiştir Sene 60

15 Asitaneden gelmiștir İplik mübayaası için Sene 60

16 Asitaneden gelmiştir Şeriki İplik mübayaası için Sene 60 Giridli
Mesleği

Fiziksel Özellikleri

İsim Ya

Çerci

Koyun

Taciri

Orta Boylu Mehmed bin Bekir 45 Kumral

Sakall1

Uzun Boylu Mehmed bin Musa 36

Kara Sakallı

Hamal Orta Boylu Halil bin Hac1 23 Kumral İbrahim

Müzellef

Sakall1

Hamal Orta Boylu Ali bin Ahmed 25

Kumral

Bıyıkl1

Hamal Orta Boylu Dolam oğlu Ali bin 20

Ter Bıyıklı ～Mehmed

Hamal Uzun Boylu Ahmed bin 42

Kara Sakallı Süleyman

Irgad Orta Boylu Zenci Çolak oğlu 25

Ter Bıyıklı Hacı Ömer...

Abdullah bin

Abdullah

Hamal Orta Boylu Çalak oğlu Mehmed 35

Kara Sakallı bin Hüseyin

Eskici Orta Boylu Emeksiz oğlu 28

Müzellef Abduulah bin İsmail

Kara Sakall

Terzi Orta Boylu Kasab Hac1 22

Kalfası Kara Az Mehmed oğlu

Bıyıklı İbrahim bin

Han Orta Boylu Ali bin Abdullah 28

Hademesi Sarı Biyıklı

İplik Orta Boylu Gedizli Mehmed 33

Tüccar1 Kumral Az Efendi bin Ahmed

Sakall1

Orta Boylu Hacı Süleyman bin 35

Kumral

Hüseyin

Sakallı 


\begin{tabular}{|c|c|c|c|c|c|c|}
\hline No & Kişinin Geldiği Yer & $\begin{array}{c}\text { Yakınlık } \\
\text { Derecesi } \\
\text { ve } \\
\text { Maiyetini } \\
\text { n Niteliği } \\
\text { ve Görevi }\end{array}$ & Mesleği & $\begin{array}{c}\text { Fiziksel } \\
\text { Özellikleri }\end{array}$ & İsim & $\begin{array}{c}\text { Ya } \\
\mathbf{s}\end{array}$ \\
\hline 17 & $\begin{array}{l}\text { Asitaneden gelmiştir } \\
\text { ticaret için Sene } 61\end{array}$ & & $\begin{array}{l}\text { Ayak } \\
\text { Tüccar1 }^{83}\end{array}$ & $\begin{array}{l}\text { Uzunca } \\
\text { Boylu } \\
\text { Kumral } \\
\text { Sakallı }\end{array}$ & $\begin{array}{l}\text { Mehmed } \\
\text { Mustafa }\end{array}$ & 43 \\
\hline 18 & $\begin{array}{l}\text { Antakya canibinden } \\
\text { gelmiştir Sene } 57\end{array}$ & & Uncu & $\begin{array}{l}\text { Orta Boylu } \\
\text { Kara Sakallı }\end{array}$ & $\begin{array}{l}\text { Şahin Mehmed bin } \\
\text { Halil }\end{array}$ & 4 \\
\hline 19 & $\begin{array}{ll}\text { Erzurum } & \text { canibinden } \\
\text { gelmiştir. } & \text { Sene } \quad 60 \\
\text { Bayburtlu } & \end{array}$ & & $\begin{array}{l}\text { Ağnam } \\
\text { tüccarı }\end{array}$ & $\begin{array}{l}\text { Orta Boylu } \\
\text { Kara Az } \\
\text { Biy1klı }\end{array}$ & Hüseyin bin Ahmed & 24 \\
\hline 20 & $\begin{array}{ll}\text { Erzurum } & \text { canibinden } \\
\text { gelmiştir. } & \text { Sene } 60\end{array}$ & Refiki & & $\begin{array}{l}\text { Orta Boylu } \\
\text { Kara Sakallı }\end{array}$ & İbrahim bin Ali & 40 \\
\hline
\end{tabular}

Bayburtlu

\section{Mustafa Paşa Hanı ${ }^{84}$}

Denizli Kazas1 canibinden gelmiştir

1 Sene 60

Misir canibinden

2 gelmiştir Sene 58

Çulha

Orta Boylu Deli koz oğlu İsmail

Orta Boylu Arap Hacı Bedevi

Şekerci Kara Sakallı bin Davud 56

Şam-1 Şerif canibinden

3 gelmiştir Sene 61

Denizli Kazas1

canibinden gelmiştir

$4 \quad \begin{array}{ll}\text { Sene } 60 \\ \text { Denizli Kazas1 }\end{array}$

canibinden gelmiştir

5 Sene 60

Simav Kazas1

canibinden gelmiştir

6 Sene 60

Misır canibinden

7 gelmiştir Sene 61

Mimar Han ${ }^{85}$

1 Isparta Kazas1 canibinden gelmiştir Sene 61

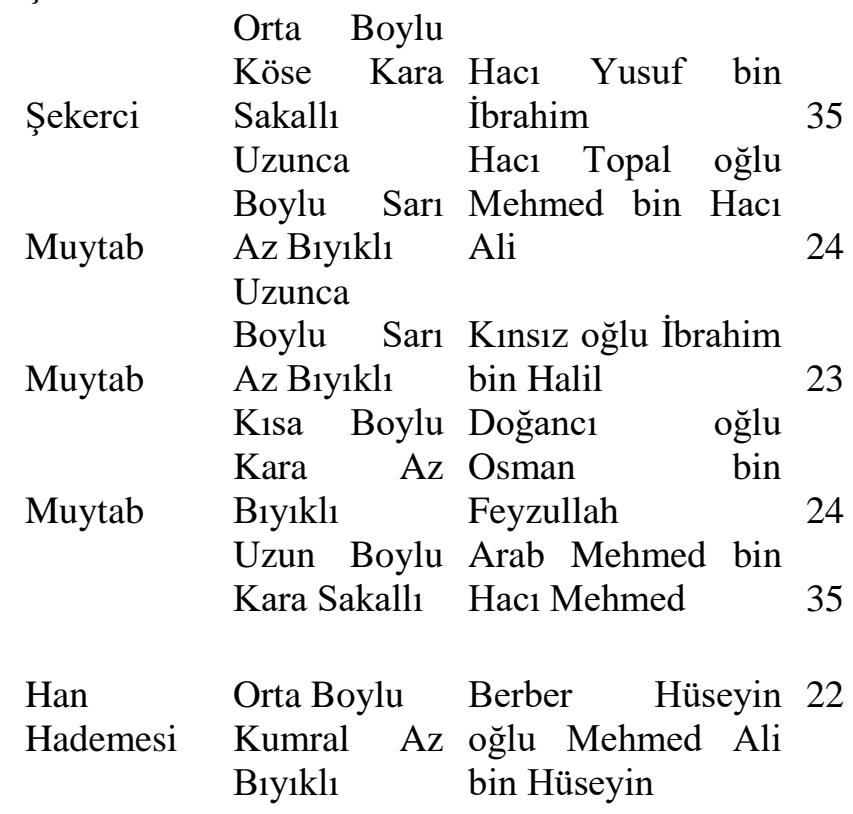

\footnotetext{
${ }^{83}$ Muhtemelen bu kişiler dükkânı olmayan tüccarlardı. Ayrıntılı bilgi için bkz. Saim Çağrı Kocakaplan, Temettüât Defterleri Çerçevesinde Silistre Kazası'nın İktisadî ve Sosyal Yapısı, Basılmamış Yükssek Lisans Tezi, Marmara Üniversitesi, Sosyal Bilimler Enstitüsü, İstanbul 2007, s. 83.

${ }^{84}$ BOA, NFS.d. 3013, s. 19.

${ }^{85}$ BOA, NFS.d. 3013, s. 19.
} 


\section{No Kişinin Geldiği Yer}

Isparta canibinden gelmiştir Sene 61

3 Tire Kazasindan gelmiş̧ir Sene 57

Osmanzade $\mathrm{HanI}^{86}$

Eğin

Canibinden

1 gelmiştir Sene 54

Denizli Kazas1 canibinden gelmiştir

2 Sene 59 Buldanl

Denizli Kazas1 canibinden gelmiştir

3 Sene 60 Buldanl

Denizli Kazas1 canibinden gelmiştir

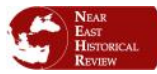

$10 / 2$

April

2020

Denizli Kazas1 canibinden gelmiştir

5 Sene 60 Buldanl
Yakınlık
Derecesi
ve
Maiyetini
n Niteliği
ve Görevi

Hamal Orta Boylu Süleyman Konya 30

Kara Sakallı bin Hasan

... Çavuşu Orta Boylu Hamamcı Şerif oğlu 30

Sarı Bıyıklı Murad bin Şerif

Orta Boylu

Hanc1 Kara Biyıklı Mustafa bin Halil 25

Orta Boylu Hüseyin oğlu Habib

Çulha Ter Bıyıklı bin Hüseyin 18

Orta Boylu

Kumral Az Kel oğlu Süleyman

$\begin{array}{lll}\text { Çulha Biyklı } & \text { bin Mustafa } & 27\end{array}$

Orta Boylu

Çulha Ter Kumral Şaher oğlu İbrahim

Kalfası Bıyıklı bin Ahmed 18

Uzunca

Denizli Kazas1 canibinden gelmiştir

6 Sene 59 Buldanl

Denizli Kazas1 canibinden gelmiştir

$7 \quad$ Sene 59

Karındaşı

Çulha

Boylu Ter Köse Ahmed oğlu

Kalfas1

Kumral

Süleyman bin

Biyıklı

Ahmed

Orta Boylu ... oğlu Mehmed bin

Çulha Kara Biyıklı Hacı Ahmed 25

Uzunca

Boylu Şabb-1

Emred İbrahim

Uzunca

Denizli Kazas1 canibinden gelmiştir

8 Sene 61 Buldanlı

Denizli Kazası canibinden gelmiştir

9 Sene 60 Buldanlı

Denizli Kazası canibinden gelmiştir

10 Sene 60 Buldanlı

Karacasu Kazasından 11 gelmiştir Sene 61
Boylu

Çulha

Kalfas1

Kumral

Sakalli

Uzunca

Çulha

Boylu Şabb-1

Kara Mehmed oğlu

Mustafa

Mehmed

bin

Emred

Hüseyin oğlu
bin Hüseyin

Orta Boylu Certan oğlu

Çulha Şabb-1 Emred Mahmud bin Ali 18 Orta Boylu

Müzellef Gök oğlan oğlu

Kumral Mehmed bin

Çulha Sakallı Mustafa

${ }^{86}$ BOA, NFS.d. 3013, s. 19-20. 


\section{No Kișinin Geldiği Yer Yakınlık \\ Derecesi \\ ve \\ Maiyetini \\ n Niteliği \\ ve Görevi}

Denizli Kazas1 canibinden gelmiştir

12 Sene 59 Buldanl

Denizli Kazas1 canibinden gelmiştir

13 Sene 60 Buldanl

Muytap Hani $^{87}$

1 Denizl canibinden gelmiştir Sene 60 Manastır Karyeli

2 Denizli canibinden gelmiştir Sene 60

3 Denizli Kazası canibinden gelmiștir Sene 60 Birgili

Balcıoğlu Hanı $^{88}$

1 Aydınl

2 Isparta Kazas1 canibinden gelmiştir Sene 54 Yalvaşlı

3 Isparta Kazası Oğlu canibinden gelmiştir Sene 54

4 Isparta Kazas1 canibinden gelmiştir Sene 57 Yalvaşlı

5 Isparta Kazası Oğlu canibinden gelmiştir Sene 57

6 Isparta Kazas1 canibinden gelmiștir Sene 59 Yalvaşlı

7 Isparta Kazas canibinden gelmiştir Sene 57 Yalvaşlı

8 Isparta Kazasi canibinden gelmiştir Sene 59 Yalvaşlı
Mesleği

Fiziksel Özellikleri

İsim Ya

Çulha

Çırağı

Çulha

Kalfas1

Orta Boylu

Köse Kumral Kadı Beşe Mehmed

Sakallı

bin Halil Day1

Orta Boylu Kör Osman oğlu

Şabb-1 Emred Mehmed bin Habib 18

Muytab

Orta Boylu Şerif oğlu Ahmed 52

Kır Sakallı bin Molla Mehmed

Hüseyin

Muytab

Orta Boylu Veli oğlu Ahmed 22 Ter Kara bin Hüseyin

Bıyıklı

Kahveci Orta Boylu Sağır Süleyman bin 50

Kırca Sakallı Ahmed

Çulha Orta Boylu Ömer bin İbrahim 48

Kir sakall1

$10 / 2$

April

Orta Boylu İbrahim

Ter Biyıklı

Çulha

Orta Boylu

Veli oğlu Ali bin 56

Kir sakallı Veli

Orta Boylu İbrahim

20

Ter Biyıklı

Çulha

Orta Boylu

Hacı Mustafa oğlu 26

Sarı Sakallı

Hüseyin

bin

Mustafa

Çulha

Uzun Boylu Börekçi oğlu 24

Kalfas1

Sar1

$\mathrm{Az}$

Ahmed bin Molla

Biyıkl1

Hüseyin

Çulha

Uzun Boylu

Sağır oğlu Salih bin 30

Kara Bıyıklı Süleyman

${ }^{87}$ BOA, NFS.d. 3013, s. 20

${ }^{88}$ BOA, NFS.d. 3013, s. 20. 


\section{No Kişinin Geldiği Yer \\ 9 Isparta Kazas1 canibinden gelmiştir Sene 54 Yalvaşlı \\ 10 Isparta Kazas1 canibinden gelmiştir Sene 61 Yalvaşlı}

11 Isparta Kazas1 canibinden gelmiştir Sene 61 Yalvaşlı

12 Isparta Kazas1 canibinden gelmiştir Sene 61 Yalvaşlı

13 Isparta Kazas1 canibinden gelmiştir Sene 61 Yalvaşlı

14 Isparta Kazas1 canibinden gelmiştir Sene 61 Yalvaşlı

15 Kismet tarikiyle Çanakkale canibinden gelmiștir Sene 61

Tekke Odası $^{89}$

1 Yeddinde olan tezkere mucibince asakir-i Nizamiye-i

Şahaneden ihraç sene 59 Reft Pınarbaşı Mahalle

2 Denizli Kazas1 canibinden gelmiştir Sene $59 \quad$ Nakil Güzelhisar Balc1 Mahallesine Temmuz 62

3 Kütahya Canibinden gelmiştir Sene 59 Reft Mahalle-i Balc1 5 Rebiü'l-Ahir 62

4 Isparta Kazas1 Canibinden gelmiştir Sene 60

\section{Yakınlık \\ Derecesi \\ ve \\ Maiyetini \\ n Niteliği \\ ve Görevi}

Mesleği

Çulha

Çulha

Çulha

Çulha

Çulha

Çulha

Han

Hademesi

Fiziksel

Özellikleri

İsim

Ya

ş

Uzun Boylu Çakal oğlu Osman 42

Sarı Sakallı

bin Ahmed

Orta Boylu Mavi oğlu Osman 38

Kara Sakallı bin İbrahim

Orta Boylu Kara bey oğlu Ali 45

Kara Sakallı bin Mehmed

Orta Boylu İsa Süleyman oğlu 40

Köse Kara İsa bin Süleyman

Sakalli

Orta Boylu Molla Hasan oğlu 31

Kara Sakallı İsmail bin Mehmed

Ali

Orta Boylu Eğriboyun oğlu 35

Kara Sakallı Yusuf bin Hüseyin

Orta Boylu Osman bin Ali 20

Kumral Az

Biyıklı

Basmac1 Orta Boylu Pirli Yiğit oğlu 41

Esnafindan Kumral

Biyıklı

Mehmed bin Molla

Hasan

Yemenici Kısa Boylu Kâhya Osman oğlu 32

Esnafindan Kara Biyıklı Mehmed bin Osman

Sol ayağı

topal

Yemenici Orta Boylu Odabaş1 oğlu 23

Esnafindan Kumral Az Hüseyin bin

Bıyıklı Süleyman

Zenne Orta Boylu Savlu oğlu Hüseyin 18

Pabuç Ter Bıyıklı bin Mehmed

${ }^{89}$ BOA, NFS.d. 3013, s. 21. 


\section{No Kişinin Geldiği Yer Yakınlık Derecesi \\ ve \\ Maiyetini \\ n Niteliği \\ ve Görevi}

5 Nazilli Kazasından gelmiştir Sene 52

$6 \quad$ Isparta Kazas1 Canibinden gelmiştir Sene 60

7 Isparta Kazas1 Canibinden gelmiştir Sene 58

8 Isparta Kazas1 Canibinden gelmiştir Sene 59

9 Dazkırı Kazası canibinden gelmiştir Sene 57

10 Mekke-i Mükerremeden ticaret içün gelmiştir Sene 59

11 Asitaneden gelmiştir Sene 60

12 Isparta Kazas1 canibinden gelmiştir Sene 61

13 Isparta Kazas1 canibinden gelmiştir Sene 61

14 Isparta Kazas1 canibinden gelmiştir Sene 59

15 Denizli canibinden gelmiştir Sene 61

16 Denizli canibinden gelmistir Sene 61

17 Isparta Kazas1 canibinden gelmiştir Sene 61

$\underset{\text { Hanı }^{90}}{\text { Hacı }}$ Ali Efendi

\section{Mesleği}

Fiziksel Özellikleri

İsim Ya

ş

Zenne

Pabuç

Dikici

Zenne

Pabuç

Dikici

Yemenici

Kalfas1

Zenne

Pabuç

Dikici

Yemenici

Esnafindan

Şekerci

Orta Boylu Ter Bıyıklı

Orta Boylu
Kara Bıyıklı

Ali Kethüda oğlu 25

Orta Boylu

Ter Bıyıklı

Orta Boylu

Ter Biyıklı

Orta Boylu

Ter Bıyıklı

Orta Boylu

Sünbül

Ali bin Mustafa

Durmuş oğlu Ali bin 18

Mehmed

Kara oğlu Salih bin 18

Ahmed

Cancan oğlu Ahmed 20 bin Mehmed

Yemenic

Orta Boylu

Kır Sakallı

Pabuççu

Uzunca

Boylu

Kara Sakallı

Pabuççu

Orta Boylu

Kalfas1

Sar1 Sakallı

Zenne

Pabuç

Dikici

Yemenici

Orta Boylu

Ter Bıyıklı

Şeyh Hacı Ömer bin 25

Ali

Derviş Mehmed bin 60

Salih

Konyalı oğlu 40

Mustafa bin İsmail

oğlu 22

Hızır oğlu Mustafa 35

bin İsmail

Uşaklı oğlu Mustafa 19

bin İbrahim

Orta Boylu Kamer oğlu Osman 45

Kır Sakallı bin Mehmed

Yemenici

Orta Boylu Yağc1 Hasan oğlu 23

Kalfas1

Kara

Biyıkl1

Yemenici

Orta Boylu

$\mathrm{Az}$ Mehmed bin Hasan

Kalfas1
Biyıklı

90 BOA, NFS.d. 3013, s. 21-22. 
$\begin{array}{cc}\text { No Kişinin Geldiği Yer } & \text { Yakınlık } \\ & \text { Derecesi } \\ \text { ve } \\ \text { Maiyetini } \\ \text { n Niteliği } \\ \text { ve Görevi }\end{array}$

1 Kütahya Canibinden gelmiştir Sene 49 Simavlı

2 Denizli Kazas1 canibinden gelmiştir Sene 60 Buldanl 1

3 İskenderiye Canibinden gelmiştir Sene 61 Sirozlu

4 Ticaret tarikiyle Sobice kazasına gelmiştir Sene 60

5 Denizli Kazas1 canibinden gelmiştir Sene 60 Buldanl1

6 Denizli r Kazas1 Sene 60 Buldanl 1

7 Kuyucak Kazasından gelmiştir Sene 59
Mesleği

Fiziksel Özellikleri

İsim Ya

Ş

8 Tavas Kazas1 canibinden gelmiştir Sene 60 Yarangümeli

9 Denizli Kazas1 canibinden gelmiştir Sene 60 Kadıköylü

10 Denizli Kazası canibinden gelmiştir Sene 60 Kadıköylü

11 Burdur Kazas1 caniinden gelmiştir Sene 61

12 Denzili Kazası canibinden gelmiștir Sene 60 Kadıköylü

13 Karacasu Kazasindan gelmiştir Sene 60

14 Yeddinde berat-1 alişan mucibince asakir-i nizamiye-i şahaneden tekaüd Sene 60 mahiyye 15
Han

Odabaşı1s

Çulha

Kahveci

$\begin{array}{ll}\text { Kara Sakallı } & \\ \text { Orta Boylu } & \text { Hacı Abdurrahman } 25 \\ \text { Sarı Sakallı } & \text { bin Hacı İbrahim }\end{array}$

Çulha Orta Boylu Akoğlan oğlu Ali 23

Ter Kumral bin Ahmed

Biyikl1

Çulha Orta Boylu Ahmed bin Mustafa 26

Kalfası Kara Sakallı

Çulha Orta Boylu Tabak oğlu 25

Kalfası Sarı Biyıklı Mehmed bin

Çulha Orta Boylu Mehmed bin 38

Seyrek Kara Hüseyin

Sakall1

Çulha Orta Boylu Hasan Dayı bin Ali 55

Kalfası Köse kır Beşe

Sakallı

Çulha Orta Boylu Tolaç oğlu Ali bin 28

Köse Kumral Hacı Mehmed

Sakallı

Çulha Orta Boylu Ali bin Mehmed 35

Kara Sakall

Çulha Orta Boylu Mehmed bin Hac1 18

Kalfası Şabb-1 Emred İsmail

Çulha Orta Boylu Mehmed bin 18

Kalfas1 Ter Kumral İbrahim

Biylkl1

Kahveci Orta Boylu Pirli Canbaz 30

Kumral İbrahim oğlu

Biyıklı Mehmed bin 


\begin{tabular}{|c|c|c|c|c|c|c|}
\hline No & Kişinin Geldiği Yer & $\begin{array}{c}\text { Yakınlık } \\
\text { Derecesi } \\
\text { ve } \\
\text { Maiyetini } \\
\text { n Niteliği } \\
\text { ve Görevi }\end{array}$ & Mesleği & $\begin{array}{l}\text { Fiziksel } \\
\text { Özellikleri }\end{array}$ & İsim & $\mathbf{Y}$ \\
\hline 15 & $\begin{array}{l}\text { Sivas canibinden } \\
\text { gelmiştir Sene } 53\end{array}$ & & Manav & $\begin{array}{l}\text { Orta Boylu } \\
\text { Kumral } \\
\text { Biyikl1 }\end{array}$ & $\begin{array}{l}\text { Aşir oğlu İbrahim } \\
\text { bin Hasan }\end{array}$ & 28 \\
\hline 16 & $\begin{array}{l}\text { Kütahya canibinden } \\
\text { gelmiştir Sene } 57 \text { Çal } \\
\text { Kazasından }\end{array}$ & & Manav & $\begin{array}{l}\text { Orta Boylu } \\
\text { Kumral } \\
\text { Biyıklı }\end{array}$ & Salih bin Hasan & 22 \\
\hline 17 & $\begin{array}{l}\text { Balıkesir canibinden } \\
\text { gelmiştir Sene } 51 \\
\text { Kör Keçiler Hanı }{ }^{91}\end{array}$ & & Çulha & $\begin{array}{l}\text { Orta Boylu } \\
\text { Kisa Kara } \\
\text { Sakallı }\end{array}$ & $\begin{array}{l}\text { Haci Mehmed Ali } \\
\text { bin Mehmed }\end{array}$ & 45 \\
\hline 1 & $\begin{array}{l}\text { Bolu Kazasına tabi } \\
\text { Mudullu'dan gelmiştir } \\
\text { Sene } 58\end{array}$ & & $\begin{array}{l}\text { Demirci } \\
\text { esnafindna }\end{array}$ & $\begin{array}{l}\text { Orta Boylu } \\
\text { İnce Kara } \\
\text { Biyıklı }\end{array}$ & $\begin{array}{l}\text { Kara Mustafa oğlu } \\
\text { Mehmed } \\
\text { Mustafa }\end{array}$ & 25 \\
\hline 2 & $\begin{array}{l}\text { Muğla canibinden } \\
\text { gelmiştir Sene } 54\end{array}$ & & Kahveci & $\begin{array}{l}\text { Uzun Boylu } \\
\text { Kara Bıyıklı }\end{array}$ & $\begin{array}{l}\text { Zenci Ali Çavuş bin } \\
\text { Abdullah }\end{array}$ & 30 \\
\hline 3 & $\begin{array}{ll}\text { Manisa } & \text { canibinden } \\
\text { gelmiştir } & \text { Sene } 60 \\
\text { Akşehirli } & \\
\text { İnce Bayraktar Han } & \\
\mathbf{9 2}\end{array}$ & & Kebabçı & $\begin{array}{l}\text { Orta Boylu } \\
\text { Köse Sarı } \\
\text { Biyıklı }\end{array}$ & Ali bin Osman & 26 \\
\hline 1 & $\begin{array}{lr}\begin{array}{l}\text { Denizli } \\
\text { canibinden }\end{array} & \text { Kazasi } \\
\text { Sene 54 } & \text { gelmiştir }\end{array}$ & & Çulha & $\begin{array}{l}\text { Uzun Boylu } \\
\text { Kara Sakallı }\end{array}$ & $\begin{array}{l}\text { Kasab oğlu Mustafa } \\
\text { bin Mustafa }\end{array}$ & 35 \\
\hline 2 & $\begin{array}{lr}\begin{array}{l}\text { Denizli } \\
\text { canibinden }\end{array} & \text { Kazasi } \\
\text { Selmiştir } \\
\text { Karyeli }\end{array}$ & & Çulha & $\begin{array}{l}\text { Orta Boylu } \\
\text { Kumral } \\
\text { Sakallı }\end{array}$ & $\begin{array}{l}\text { Çapkın oğlu Ahmed } \\
\text { bin Himmet }\end{array}$ & 35 \\
\hline 3 & $\begin{array}{lr}\begin{array}{l}\text { Denizli } \\
\text { canibinden }\end{array} & \begin{array}{r}\text { Kazas1 } \\
\text { gelmiştir }\end{array} \\
\text { Sene } 60 \text { Kadıköylü }\end{array}$ & & Çulha & $\begin{array}{l}\text { Uzun Boylu } \\
\text { Kur Sakallı }\end{array}$ & Yusuf bin Süleyman & 48 \\
\hline 4 & $\begin{array}{lr}\begin{array}{l}\text { Denizli } \\
\text { canibinden }\end{array} & \text { Kazasi } \\
\text { Sene } 60 & \end{array}$ & & $\begin{array}{l}\text { Çulha } \\
\text { Kalfası }\end{array}$ & $\begin{array}{l}\text { Orta Boylu } \\
\text { Kumral } \\
\text { Biyıklı }\end{array}$ & Ali bin İsmail & 28 \\
\hline 5 & $\begin{array}{lr}\begin{array}{l}\text { Denizli } \\
\text { canibinden }\end{array} & \text { Kazas1 } \\
\text { Sene } 60 & \end{array}$ & & $\begin{array}{l}\text { Çulha } \\
\text { Kalfası }\end{array}$ & $\begin{array}{l}\text { Uzunca } \\
\text { Boylu } \\
\text { Ter Kumral } \\
\text { Biyıklı }\end{array}$ & $\begin{array}{l}\text { Himmet } \\
\text { Mustafa }\end{array}$ & 18 \\
\hline 6 & $\begin{array}{lr}\text { Uluborlu } & \text { Kazasi } \\
\text { canibinden } & \text { gelmiştir }\end{array}$ & & Çulha & $\begin{array}{l}\text { Orta Boylu } \\
\text { Kara Sakallı }\end{array}$ & $\begin{array}{l}\text { Hasan bin Bekir } \\
\text { oğlu Mustafa }\end{array}$ & 35 \\
\hline
\end{tabular}

\footnotetext{
${ }^{91}$ BOA, NFS.d. 3013, s. 22.

92 BOA, NFS.d. 3013, s. 22-23.
} 


\begin{tabular}{|c|c|c|c|c|c|c|c|}
\hline No & Kişinin Ge & diği Yer & $\begin{array}{c}\text { Yakınlık } \\
\text { Derecesi } \\
\text { ve } \\
\text { Maiyetini } \\
\text { n Niteliği } \\
\text { ve Görevi }\end{array}$ & Mesleği & $\begin{array}{l}\text { Fiziksel } \\
\text { Özellikleri }\end{array}$ & İsim & $\begin{array}{c}\text { Ya } \\
\text { Ş }\end{array}$ \\
\hline 7 & $\begin{array}{l}\text { Uluborlu } \\
\text { canibinden } \\
\text { Sene } 60\end{array}$ & $\begin{array}{r}\text { Kazas1 } \\
\text { gelmiştir }\end{array}$ & & $\begin{array}{l}\text { Çulha } \\
\text { Kalfası }\end{array}$ & $\begin{array}{l}\text { Uzunca } \\
\text { Boylu } \\
\text { Kumral Az } \\
\text { Biy1kl1 }\end{array}$ & İsmail bin Mustafa & 23 \\
\hline 8 & $\begin{array}{l}\text { Uluborlu } \\
\text { canibinden } \\
\text { Sene } 60\end{array}$ & $\begin{array}{r}\text { Kazasi } \\
\text { gelmiştir }\end{array}$ & & Çulha & $\begin{array}{l}\text { Orta Boylu } \\
\text { Köse Kırca } \\
\text { Sakallı }\end{array}$ & $\begin{array}{l}\text { İlyas oğlu Hasan bin } \\
\text { Süleyman }\end{array}$ & 52 \\
\hline 9 & $\begin{array}{l}\text { Uluborlu } \\
\text { canibinden } \\
\text { Sene } 60\end{array}$ & $\begin{array}{r}\text { Kazasi } \\
\text { gelmiştir }\end{array}$ & & $\begin{array}{l}\text { Çulha } \\
\text { Kalfası }\end{array}$ & $\begin{array}{l}\text { Uzunca } \\
\text { Boylu } \\
\text { Kumral Az } \\
\text { Biyılil }\end{array}$ & $\begin{array}{l}\text { İlyas oğlu Hasan bin } \\
\text { Hasan }\end{array}$ & 22 \\
\hline 10 & $\begin{array}{l}\text { Denizli } \\
\text { canibinden } \\
\text { Sene } 60 \mathrm{Kad}\end{array}$ & $\begin{array}{l}\text { Kazası } \\
\text { gelmişstir } \\
\text { köylü }\end{array}$ & & Çulha & $\begin{array}{l}\text { Uzunca } \\
\text { Boylu } \\
\text { Kır Sakallı }\end{array}$ & $\begin{array}{lr}\text { Kulaksiz } & \text { oğlu } \\
\text { Hüseyin } & \text { bin } \\
\text { Mehmed } & \end{array}$ & 50 \\
\hline 11 & $\begin{array}{l}\text { Denizli } \\
\text { canibinden } \\
\text { Sene } 60\end{array}$ & $\begin{array}{r}\text { Kazasi } \\
\text { gelmiştir }\end{array}$ & Oğlu & & & Mehmed & 13 \\
\hline 12 & $\begin{array}{l}\text { Denizli } \\
\text { canibinden } \\
\text { Sene } 60 \mathrm{Kad}\end{array}$ & $\begin{array}{l}\text { Kazası } \\
\text { gelmişstir } \\
\text { köylü }\end{array}$ & & Çulha & $\begin{array}{l}\text { Orta Boylu } \\
\text { Kir sakallı }\end{array}$ & $\begin{array}{l}\text { Anasız oğlu Ömer } \\
\text { bin Mustafa }\end{array}$ & 56 \\
\hline 13 & $\begin{array}{l}\text { Denizli } \\
\text { canibinden } \\
\text { Sene } 60\end{array}$ & $\begin{array}{r}\text { Kazasi } \\
\text { gelmiştir }\end{array}$ & Oğlu & & $\begin{array}{l}\text { Orta Boylu } \\
\text { Müzellef } \\
\text { Kumral } \\
\text { Sakallı }\end{array}$ & Ahmed & 26 \\
\hline 14 & $\begin{array}{l}\text { Denizli } \\
\text { canibinden } \\
\text { Sene } 60\end{array}$ & $\begin{array}{r}\text { Kazasi } \\
\text { gelmiştir }\end{array}$ & Oğlu & & $\begin{array}{l}\text { Orta Boylu } \\
\text { Ter Kara } \\
\text { Biyıkl1 }\end{array}$ & Mehmed & 20 \\
\hline 15 & $\begin{array}{l}\text { Denizli } \\
\text { canibinden } \\
\text { Sene } 60 \mathrm{Kad}\end{array}$ & $\begin{array}{l}\text { Kazası } \\
\text { gelmişstir } \\
\text { köylü }\end{array}$ & & $\begin{array}{l}\text { Çulha } \\
\text { Kalfası }\end{array}$ & $\begin{array}{l}\text { Orta Boylu } \\
\text { Ter Biyıklı }\end{array}$ & $\begin{array}{l}\text { Hac1 Abbak oğlu } \\
\text { Salih bin Ali }\end{array}$ & 18 \\
\hline 16 & $\begin{array}{l}\text { Denizli } \\
\text { canibinden } \\
\text { Sene } 61 \mathrm{Kad}\end{array}$ & $\begin{array}{l}\text { Kazası } \\
\text { gelmişstir } \\
\text { köylü }\end{array}$ & & Çulha & $\begin{array}{l}\text { Uzun Boylu } \\
\text { Kumral } \\
\text { Sakallı }\end{array}$ & $\begin{array}{l}\text { İnad oğlu Ahmed } \\
\text { bin Mehmed }\end{array}$ & 28 \\
\hline 17 & $\begin{array}{l}\text { Denizli } \\
\text { canibinden } \\
\text { Sene } 61\end{array}$ & $\begin{array}{r}\text { Kazasi } \\
\text { gelmiştir }\end{array}$ & & $\begin{array}{l}\text { Çulha } \\
\text { Kalfası }\end{array}$ & $\begin{array}{l}\text { Orta Boylu } \\
\text { Kara Sakallı }\end{array}$ & $\begin{array}{l}\text { Kara Ahmed oğlu } \\
\text { Yusuf bin Ahmed }\end{array}$ & 31 \\
\hline 18 & $\begin{array}{l}\text {... Kazası } \\
\text { gelmiştir Sen }\end{array}$ & $\begin{array}{l}\text { anibinden } \\
\text { e } 60\end{array}$ & & Çulha & $\begin{array}{l}\text { Orta Boylu } \\
\text { Sar1 Sakallı }\end{array}$ & Ali bin Osman & 40 \\
\hline 19 & $\begin{array}{l}\text { Karacasu } \\
\text { canibinden } \\
\text { Sene } 60\end{array}$ & $\begin{array}{r}\text { Kazası } \\
\text { gelmiştir }\end{array}$ & & Çulha & $\begin{array}{l}\text { Uzun Boylu } \\
\text { Kumral } \\
\text { Sakallı }\end{array}$ & $\begin{array}{l}\text { Kabakçı oğlu } \\
\text { Ahmed bin Ali }\end{array}$ & 30 \\
\hline 20 & $\begin{array}{l}\text { Karacasu } \\
\text { canibinden } \\
\text { Sene } 60\end{array}$ & $\begin{array}{r}\text { Kazas1 } \\
\text { gelmiştir }\end{array}$ & & $\begin{array}{l}\text { Çulha } \\
\text { Kalfası }\end{array}$ & $\begin{array}{l}\text { Orta Boylu } \\
\text { Kumral } \\
\text { Biyıklı }\end{array}$ & $\begin{array}{l}\text { Mehmed şirin oğlu } \\
\text { Süleyman } \\
\text { Osman }\end{array}$ & 28 \\
\hline
\end{tabular}




\begin{tabular}{|c|c|c|c|c|c|c|c|}
\hline No & Kişinin Ge & Idiği Yer & $\begin{array}{c}\text { Yakınlık } \\
\text { Derecesi } \\
\text { ve } \\
\text { Maiyetini } \\
\text { n Niteliği } \\
\text { ve Görevi }\end{array}$ & Mesleği & $\begin{array}{c}\text { Fiziksel } \\
\text { Özellikleri }\end{array}$ & İsim & $\begin{array}{c}\mathbf{Y a} \\
\mathbf{s}\end{array}$ \\
\hline 21 & $\begin{array}{l}\text { Karacasu } \\
\text { canibinden } \\
\text { Sene } 60\end{array}$ & $\begin{array}{r}\text { Kazası } \\
\text { gelmiştir }\end{array}$ & & $\begin{array}{l}\text { Çulha } \\
\text { Kalfası }\end{array}$ & $\begin{array}{l}\text { Orta Boylu } \\
\text { Kumral } \\
\text { Biyıklı }\end{array}$ & $\begin{array}{l}\text { Molla Ahmed oğlu } \\
\text { Hasan bin Ahmed }\end{array}$ & 26 \\
\hline 22 & $\begin{array}{l}\text { Denizli } \\
\text { canibinden } \\
\text { Sene } 58 \mathrm{Kad}\end{array}$ & $\begin{array}{r}\text { Kazası } \\
\text { gelmiştir } \\
\text { köylü }\end{array}$ & & $\begin{array}{l}\text { Çulha } \\
\text { Kalfası }\end{array}$ & $\begin{array}{l}\text { Orta Boylu } \\
\text { Ter Kumral } \\
\text { Biyıkl1 }\end{array}$ & $\begin{array}{l}\text { Tuna oğlu Mustafa } \\
\text { bin Ahmed }\end{array}$ & 20 \\
\hline 24 & $\begin{array}{l}\text { Tavas } \\
\text { canibinden } \\
\text { Sene } 60 \text { Yara }\end{array}$ & $\begin{array}{l}\text { Kazas1 } \\
\text { gelmişstir } \\
\text { angümeli }\end{array}$ & & $\begin{array}{l}\text { Çulha } \\
\text { Çırağ }\end{array}$ & $\begin{array}{l}\text { Orta Boylu } \\
\text { Ter Kara } \\
\text { Biyıklı }\end{array}$ & $\begin{array}{l}\text { Memiş oğlu İsmail } \\
\text { bin Ahmed }\end{array}$ & 18 \\
\hline 25 & $\begin{array}{l}\text { Uluborlu } \\
\text { canibinden } \\
\text { Sene } 60 \text { Ulub } \\
\text { Deliler Hanı }\end{array}$ & $\begin{array}{l}\text { Kazasi } \\
\text { gelmiştir } \\
\text { gorlu } \\
\text { 93 }\end{array}$ & & Hanc1 & $\begin{array}{l}\text { Orta Boylu } \\
\text { Köse } \quad \text { Kara } \\
\text { Sakallı }\end{array}$ & $\begin{array}{l}\text { Muslu oğlu Mustafa } \\
\text { bin Ahmed }\end{array}$ & 35 \\
\hline 1 & $\begin{array}{l}\text { Kayseri } \\
\text { canibinden } \\
\text { Sene } 60\end{array}$ & $\begin{array}{r}\text { Kazası } \\
\text { gelmiştir }\end{array}$ & & Misirc1 & $\begin{array}{l}\text { Orta Boylu } \\
\text { Kır Sakallı }\end{array}$ & $\begin{array}{l}\text { Koca Veli oğlu Haci } \\
\text { İbrahim bin Mehmed }\end{array}$ & 50 \\
\hline 2 & $\begin{array}{l}\text { Kayseri } \\
\text { canibinden } \\
\text { Sene } 58\end{array}$ & $\begin{array}{r}\text { Kazası } \\
\text { gelmiştir }\end{array}$ & & Bakırc1 & $\begin{array}{l}\text { Uzun Boylu } \\
\text { Kara Sakallı }\end{array}$ & $\begin{array}{l}\text { Kalabaklı oğlu Seyid } \\
\text { Ali bin hacı Ali }\end{array}$ & 35 \\
\hline 3 & $\begin{array}{l}\text { Isparta } \\
\text { canibinden } \\
\text { Sene } 60\end{array}$ & $\begin{array}{r}\text { Kazası } \\
\text { gelmiştir }\end{array}$ & & Hamal & $\begin{array}{l}\text { Orta Boylu } \\
\text { Köse Kara } \\
\text { Sakallı }\end{array}$ & $\begin{array}{l}\text { Kemal oğlu Ömer bin } \\
\text { Ali }\end{array}$ & 37 \\
\hline 4 & $\begin{array}{l}\text { Isparta } \\
\text { canibinden } \\
\text { Sene } 60\end{array}$ & $\begin{array}{r}\text { Kazas1 } \\
\text { gelmiştir }\end{array}$ & & Hamal & $\begin{array}{l}\text { Orta Boylu } \\
\text { Kır Sakallı }\end{array}$ & $\begin{array}{l}\text { Çırak oğlu Ali bin } \\
\text { Hasan }\end{array}$ & 50 \\
\hline 5 & $\begin{array}{l}\text { Isparta } \\
\text { canibinden } \\
\text { Sene } 59\end{array}$ & $\begin{array}{r}\text { Kazası } \\
\text { gelmiştir }\end{array}$ & & Hamal & $\begin{array}{l}\text { Orta Boylu } \\
\text { Kara Biyiklı }\end{array}$ & $\begin{array}{lr}\text { Kemal } & \text { oğlu } \\
\text { Süleyman } & \text { bin } \\
\text { Mehmed } & \end{array}$ & 25 \\
\hline 6 & $\begin{array}{l}\text { Isparta } \\
\text { canibinden } \\
\text { Sene } 58\end{array}$ & $\begin{array}{r}\text { Kazas1 } \\
\text { gelmiştir }\end{array}$ & & Eskici & $\begin{array}{l}\text { Orta Boylu } \\
\text { Kumral } \\
\text { sakallı }\end{array}$ & Mehmed bin İsmail & 45 \\
\hline 7 & $\begin{array}{l}\text { Kayseri } \\
\text { canibinden } \\
\text { Sene } 60\end{array}$ & $\begin{array}{r}\text { Kazası } \\
\text { gelmiştir }\end{array}$ & & Misirc1 & $\begin{array}{l}\text { Orta Boylu } \\
\text { Kara Kisa } \\
\text { Sakallı }\end{array}$ & $\begin{array}{l}\text { Numan oğlu Halil } \\
\text { İbrahim bin Numan }\end{array}$ & 45 \\
\hline 8 & $\begin{array}{l}\text { Erzurum } \\
\text { gelmiştir Sen }\end{array}$ & $\begin{array}{l}\text { canibinden } \\
\text { le } 54\end{array}$ & & Manav & $\begin{array}{l}\text { Orta Boylu } \\
\text { Ak sakallı }\end{array}$ & $\begin{array}{l}\text { Şerif Mehmed Ağa } \\
\text { bin Yakub }\end{array}$ & 60 \\
\hline 9 & $\begin{array}{l}\text { Rodos } \\
\text { gelmiştir Sen }\end{array}$ & $\begin{array}{l}\text { canibinden } \\
\text { e } 54\end{array}$ & & Dülger & $\begin{array}{l}\text { Orta Boylu } \\
\text { Kumral } \\
\text { Biy1klı }\end{array}$ & Mustafa bin Ahmed & 28 \\
\hline 10 & $\begin{array}{l}\text { İzmir } \\
\text { gelmiştir } \\
\text { Hatuniye Ma }\end{array}$ & $\begin{array}{l}\text { canibinden } \\
\text { Sene } 58 \\
\text { hallesinden }\end{array}$ & & Nalbur & $\begin{array}{l}\text { Orta Boylu } \\
\text { Sarı Biyıklı }\end{array}$ & $\begin{array}{l}\text { Hacı Hüseyin oğlu } \\
\text { Mehmed Ağa bin } \\
\text { Hasan }\end{array}$ & 45 \\
\hline
\end{tabular}

${ }^{93}$ BOA, NFS.d. 3013, s. 23. 


\begin{tabular}{|c|c|c|c|c|c|c|}
\hline No & Kişinin Geldiği Yer & $\begin{array}{c}\text { Yakınlık } \\
\text { Derecesi } \\
\text { ve } \\
\text { Maiyetini } \\
\text { n Niteliği } \\
\text { ve Görevi }\end{array}$ & Mesleği & $\begin{array}{c}\text { Fiziksel } \\
\text { Özellikleri }\end{array}$ & İsim & $\mathbf{Y}$ \\
\hline 11 & $\begin{array}{lr}\begin{array}{l}\text { Isparta } \\
\text { canibinden }\end{array} & \text { Kazas1 } \\
\text { Sene 61 } & \text { gelmiştir }\end{array}$ & & Hamal & $\begin{array}{l}\text { Uzunca Boylu } \\
\text { Kumral } \\
\text { sakallı }\end{array}$ & $\begin{array}{l}\text { Bayram oğlu Osman } \\
\text { bin Hasan }\end{array}$ & 35 \\
\hline 12 & $\begin{array}{l}\text { Girid Adas1 canibinden } \\
\text { gelmiştir Sene } 59\end{array}$ & & $\begin{array}{l}\text { Han } \\
\text { Odabașis1 }\end{array}$ & $\begin{array}{l}\text { Orta Boylu } \\
\text { Sar1 Biylkl1 }\end{array}$ & Veli bin İbrahim & 35 \\
\hline 13 & $\begin{array}{l}\text { Kula Kazası cabinden } \\
\text { gelmiştir Sene } 61\end{array}$ & & Kahveci & $\begin{array}{l}\text { Uzun Boylu } \\
\text { Ter Kara } \\
\text { Biyıklı }\end{array}$ & Mehmed bin Halil & 20 \\
\hline 14 & $\begin{array}{l}\text { Tüfekçilik ticaretiyle ... } \\
\text { canibinden gelmiştir } \\
\text { Sene } 61\end{array}$ & & Kundakçı & $\begin{array}{l}\text { Uzunca Boylu } \\
\text { Kara Biyıklı }\end{array}$ & Abdulhamid bin Arif & 33 \\
\hline 15 & $\begin{array}{l}\text { Tüfekçilik ticaretiyle ... } \\
\text { canibinden gelmiştir } \\
\text { Sene } 61 \\
\text { Şamlı oğlu Hanı }\end{array}$ & Şeriki & Kundakçı & $\begin{array}{l}\text { Orta Boylu } \\
\text { Kumral } \\
\text { Biyıklı }\end{array}$ & Said bin Halid & 5 \\
\hline 1 & $\begin{array}{l}\text { Bozdoğan Kazasından } \\
\text { gelmiştir Sene } 58\end{array}$ & & $\begin{array}{l}\text { Kahveci } \\
\text { Tabi'si } \\
\text { (çırak) }\end{array}$ & $\begin{array}{l}\text { Orta Boylu } \\
\text { Kara Biyıklı }\end{array}$ & $\begin{array}{l}\text { Demirci Salih oğlu } \\
\text { Salih bin Salih }\end{array}$ & 22 \\
\hline 2 & $\begin{array}{l}\text { İzmir canibinden } \\
\text { gelmiştir Sene } 60\end{array}$ & & Çilingir & $\begin{array}{l}\text { Orta Boylu } \\
\text { Kumral Az } \\
\text { Biyıklı }\end{array}$ & $\begin{array}{l}\text { Haci Ahmed bin } \\
\text { Mehmed }\end{array}$ & 35 \\
\hline 3 & $\begin{array}{l}\text { Yalvaş } \\
\text { canibinden } \\
\text { Sene } 57 \\
\text { Reft Mazasıalle-i } \\
\text { Mescidir } \\
\text { Kurşunlu Hayalı } \\
\end{array}$ & & $\begin{array}{l}\text { Kahveci } \\
\text { Tabi'si }\end{array}$ & $\begin{array}{l}\text { Orta Boylu } \\
\text { Kır Sakallı }\end{array}$ & $\begin{array}{l}\text { Abdurrahman } \\
\text { Mehmed }\end{array}$ & 57 \\
\hline 1 & $\begin{array}{l}\text { Haleb canibinden } \\
\text { gelmiştir Sene } 59 \text { bab-1 } \\
\text { Makam Mahallesinden }\end{array}$ & & iccar1 & $\begin{array}{l}\text { Orta Boylu } \\
\text { Kumral az } \\
\text { Biyıklı }\end{array}$ & $\begin{array}{l}\text { Mahmud Ağa bin } \\
\text { Mehmed }\end{array}$ & 23 \\
\hline 2 & $\begin{array}{lr}\begin{array}{l}\text { Karacasu } \\
\text { canibinden }\end{array} & \text { Kazas1 } \\
\text { Sene 59 } & \text { gelmiştir }\end{array}$ & & $\begin{array}{l}\text { Kahveci } \\
\text { Tabi'si }\end{array}$ & $\begin{array}{l}\text { Orta Boylu } \\
\text { Kumral az } \\
\text { Biyıklı }\end{array}$ & $\begin{array}{l}\text { Katırci Haci Ahmed } \\
\text { oğlu İsmail bin } \\
\text { Ahmed }\end{array}$ & 24 \\
\hline 3 & $\begin{array}{l}\text { Muğla canibinden } \\
\text { gelmiştir Sene } 560 \\
\text { Yakup Paşa Hanı }^{\mathbf{9 6}}\end{array}$ & & Hamal & $\begin{array}{l}\text { Uzunca Boylu } \\
\text { Kara Biyıklı }\end{array}$ & $\begin{array}{l}\text { Çil Oğlu Memiş bin } \\
\text { Hafiz Yusuf }\end{array}$ & 30 \\
\hline 1 & $\begin{array}{l}\text { Ticaret } \quad \text { zimmiyle } \\
\text { Erzurum canibinden } \\
\text { gelmiştir Sene } 57\end{array}$ & & $\begin{array}{l}\text { Kahveci } \\
\text { Tabi'si }\end{array}$ & $\begin{array}{l}\text { Orta Boylu } \\
\text { Kumral } \\
\text { Biyıkl1 }\end{array}$ & $\begin{array}{l}\text { Derviş Ahmed bin } \\
\text { Yusuf }\end{array}$ & 40 \\
\hline 2 & $\begin{array}{l}\text { Misır canibinden } \\
\text { gelmiştir Sene } 50\end{array}$ & & seyis & $\begin{array}{l}\text { Orta Boylu } \\
\text { Kara Sakallı }\end{array}$ & $\begin{array}{l}\text { Arap Haci Mehmed } \\
\text { bin Ahmed }\end{array}$ & 40 \\
\hline
\end{tabular}

\footnotetext{
${ }^{94}$ BOA, NFS.d. 3013, s. 23.

${ }^{95}$ BOA, NFS.d. 3013, s. 24.

${ }^{96}$ BOA, NFS.d. 3013, s. 24.
} 


\begin{tabular}{|c|c|c|}
\hline No & Kişinin Geldiği Yer & $\begin{array}{l}\text { Yakınlık } \\
\text { Derecesi } \\
\text { ve } \\
\text { Maiyetini } \\
\text { n Niteliği } \\
\text { ve Görevi }\end{array}$ \\
\hline & $\underset{\text { Hanı̈ }^{97}}{\text { Körük }}=$ Gödek & \\
\hline 1 & $\begin{array}{l}\text { Antakya canibinden } \\
\text { gelmiştir Sene } 55\end{array}$ & \\
\hline 2 & $\begin{array}{l}\text { Antakya canibinden } \\
\text { gelmiştir Sene } 56\end{array}$ & \\
\hline 3 & $\begin{array}{l}\text { Antakya canibinden } \\
\text { gelmiştir Sene } 56\end{array}$ & Karındaşı \\
\hline 4 & $\begin{array}{lr}\text { Isparta } & \text { kazasi } \\
\text { canibinden } & \text { gelmiştir }\end{array}$ & \\
\hline 5 & $\begin{array}{l}\text { Sene } 59 \text { İslam Karyeli } \\
\ldots \text {. canibinden gelmiştir } \\
\text { Sene } 57\end{array}$ & \\
\hline 6 & $\begin{array}{l}\text { Antakya canibinden } \\
\text { gelmiştir Sene } 61\end{array}$ & \\
\hline 7 & 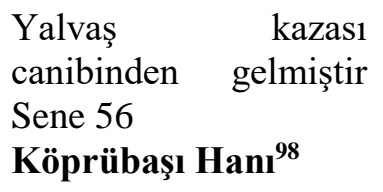 & \\
\hline 1 & 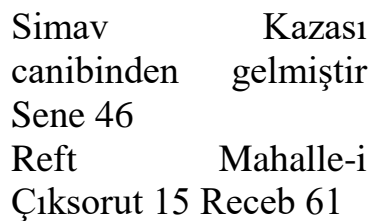 & \\
\hline 2 & $\begin{array}{lr}\begin{array}{l}\text { Simav } \\
\text { canibinden }\end{array} & \text { Kazasi } \\
\text { Sene 46 } & \text { gelmiştir }\end{array}$ & Oğlu \\
\hline & $\begin{array}{l}\text { Reft Mahalle-i } \\
\text { C1ksorut } 15 \text { Receb 61 }\end{array}$ & \\
\hline 3 & $\begin{array}{l}\text { Arpaz Kazasından } \\
\text { gelmiştir Sene } 60\end{array}$ & \\
\hline 4 & $\begin{array}{lr}\begin{array}{l}\text { Alaşehir } \\
\text { canibinden }\end{array} & \text { Kazasi } \\
\text { Sene } 57 & \text { gelmiştir }\end{array}$ & \\
\hline
\end{tabular}

\section{Mesleği \\ Meslegi}

Fiziksel Özellikleri
İsim Ya

ş

Ekmekçi Orta Boylu Mehmed bin 68 Hamurkârı Kır Sakallı Süleyman Arpac1 Orta Boylu İbrahim bin Yusuf 38 esnafindan Kumral sakall

$\begin{array}{lll}\text { Orta Boylu Ali } & 18\end{array}$

Hamal Uzun Boylu Kara Mehmed bin 28 Kara sakallı Kara Mehmed

Ekmekçi Orta Boylu Mahmud bin 25

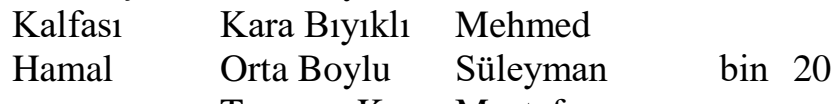
Ter Kara Mustafa Biyıklı

Kahveci Orta Boylu Ömer oğlu İsmail 26 Tabi'si Kumral bin Ömer Biyıklı

Hanc1

\begin{tabular}{lll} 
Uzunca & \multicolumn{2}{c}{ Katırcı Mustafa } \\
Boylu & \multicolumn{2}{c}{ oglu Ahmed bin } \\
Kumral & Az & Mustafa \\
Biyklı & &
\end{tabular}

$$
\text { Hüseyin }
$$

Han Orta Boylu Terzi oğlu Mustafa 24

Odabaşısı Kumral Az bin Mustafa

Kahveci

Biyıklı

Tabi'si

$\begin{array}{llc}\text { Uzunca } & \text { Boyacı } & \text { oğlu } 53 \\ \text { Boylu } & \text { Mehmed } & \text { bin } \\ \text { Kır Sakallı } & \text { Mustafa } & \end{array}$

\footnotetext{
97 BOA, NFS.d. 3013, s. 24.

${ }^{98}$ BOA, NFS.d. 3013, s. 24-25.
} 
Kahve ve Dekakinlerde sakin olan bekaran perakende ehl-i İslam ${ }^{99}$

\section{N Kişinin Geldiği Yer ve \\ o}

\section{Yakınlık \\ ve \\ Maiyetinin \\ Niteliği ve \\ Görevi}

1 Isparta Kazası canibinden gelmiştir Sene 59

Sakin-i Zeyn oğlu Medresesine

2 Isparta Kazas1 canibinden gelmiştir Sene 57

Sakin-i Zeyn oğlu Medresesine

3 Isparta Kazası canibinden gelmiştir Sene 52

Sakin yukarı Zeyn oğlu Medresesine

Reft mahalle-i Sarayiçi

4 Isparta Kazası canibinden gelmiş̧ir Sene 58

Sakin Çavuş Hanı

5 Muğla canibinden gelmiştir Sene 59

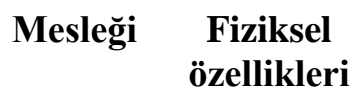

\section{Giridli}

Dede damı bahçesinde sakin

9 Aydinlı

Helvac1 Orta Boylu

Çırağı Ter Bıyıklı Kuruçıkı oğlu Ali bin Mestan

$\begin{array}{lllrl}\text { Duhan } & \text { Uzunca } & \text { Ömer } & \text { oğlu } & 45 \\ \text { Kıyıcı } & \text { Boylu } & \text { Mehmed } & \text { Emin } & \\ & \text { Kara sakallı } & \text { bin Ali } & & \end{array}$

${ }^{99}$ BOA, NFS.d. 3013, s. 25-26. 


\section{N Kişinin Geldiği Yer ve \\ o Kaldığı Yer}

\section{Yakınlık Derecesi \\ ve \\ Maiyetinin \\ Niteliği ve \\ Görevi}

12 Denizli canibinden gelmiş̧ir Sene 58

Sakin Dükkân önü Kahvesi

13 İzmir canibinden gelmiştir Sene 57 Misirl1

14

15 Arpaz Kazasindan gelip mücavir kalmıştır Sene 46 İnebolu Karyeli

Nakil Mahalle-i Güzelhisar 15 Eylül 62

16 Rodos canibinden gelmiştir Sene 58

Anahtar Ağa bahçesinde sakin

17 Rodos canibinden gelmiştir Sene 59

Sakin Almalı=Elmalı Bahçe

18 Akșehir canibinden gelmiştir Sene 50

Sakin Karanko Köprü Baş1

19 Isparta canibinden gelmiştir Sene 56

Uluborlulu

Sakin Nazilli Köprübaşı

20 Akşehir canibinden gelmiştir Sene 58

Sakin Dükkân önünde Yağhanede

21 Tire Kazasıdan gelmiştir sene 51

23 an-as11 Kayseriyeli olub Misır canibinden gelmiştir Sene 57

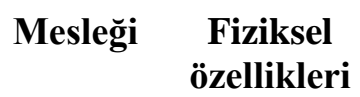

Mesleği Fiziksel özellikleri

İsim

Yaş

Kahveci Orta Boylu Nalband Kara Ali

Tabi'si Sarı Bıyıklı oğlu İsmail bin

Ali

Kahveci Orta Boylu Hac1 Mehmed bin 45

Tabi'si Kara Bıyıklı Ali

Kahveci Orta Boylu Aydınlı ... oğlu 30

Tabi'si Sarı Sakallı Derviș Mehmed

bin Hac1 Ahmed

Kahveci Uzunca Öksüz oğlu

Tabi'si Boylu Mustafa bin

Kumral Ahmed

sakallı

Bahçıva Orta Boylu Koca Halil oğlu 32

n Kara Biyıklı Yusuf bin Halil

Bahçıva Orta Boylu Üç akçe oğlu 33

n Sarı Bıyıklı Mehmed Emin

bin Mehmed

Susam Orta Boylu İsa oğlu Mustafa 36

Yağçı Kara Bıyıklı bin Osman

Helvac1 Orta Boylu Kalaycı oğlu Ali 17

Çırağı Ter Bıyıklı bin Halil

Helvac1 Orta Boylu Ali Kadı oğlu 20

Kalfası Ter Bıyıklı Mehmed bin

Mehmed

Pasvant Orta Boylu Halil bin Ahmed 25

Başı Köse Kara

neferatın Sakallı

dan ${ }^{100}$

Rençber Orta Boylu Durmuş Ali bin 38

Köse Kumral Hacı Ali

sakallı

Kahveci Uzun Boylu Deli Mehmed bin 38

Tabi'si Kara Bıyıklı Mehmed

${ }^{100}$ Rumeli'de gece bekçisi. 


\section{N Kişinin Geldiği Yer ve \\ $\mathbf{o}$ Kaldığı Yer}

Yakınlık Derecesi

ve

Maiyetinin

Niteliği ve

Görevi

Sakin kahve-i Rumiyan

24 Sille canibinden gelmiştir Sene 57

Sakin Dürrizade Medresesi

25 Bergama kazasından gelmiş̧ir Sene 58

Sakin Nalband Başı yanından

26 Akșehir canibinden gelmiştir sene 60

27 Denizli canibinden gelmiștir Sene 61 Sarayköylü

28 Denizli canibinden Karındaşı gelmiştir Sene 61

29 Uluborlu canibinden gelmiştir Sene 60

30 Akşehir canibinden gelmiştir Sene 61

31 Kuyucak Kazasindan gelmiştir Sene 45

32 Kuyucak Kazasindan gelmiştir Sene 51

33 Muğla canibinden gelmiştir Sene 51

34 Muğla canibinden gelmiştir Sene 58

Mimar Hanı kurbinde sakin

35 Antakya canibinden gelmiştir Sene 61

Sakin Ekmekçi Başı yanında

36 Muğla canininden gelmiştir Sene 52

\section{Mesleği Fiziksel özellikleri}

İsim

Yaş

Eskici Uzun Boylu İslam oğlu İsmail 38 Kumral bin İsmail

Sakall1

Nalband Kisa Boylu Yusuf bin 18

Kalfası Ter Biyıklı Mehmed

Helvac1 Orta Boylu Kara Bacak oğlu 40

Kara sakallı Hasan bin Halil

Helvac1 Orta Boylu Kasap Süleyman 23

Kumral Az oğlu Mustafa bin

Bıyıklı Süleyman

Orta Boylu Mestan

Şabb-1

Emred

Helvacı Orta Boylu Mavi oğlu Ahmed 17

Kalfası Şabb-1 bin Osman

Emred

Helvac1 Orta Boylu Hatib oğlu 18

Kalfası Ter Kumral Mustafa bin Bıyıklı Molla İbrahim

Ekmekçi Orta Boylu Hacı Halil oğlu 58

Köse Kır Mehmed bin Hacı

Sakallı Halil

Ekmekçi Uzunca Ocak oğlu 25

Boylu Mustafa bin

Kumral Ahmed

Biyıklı

Ekmekçi Orta Boylu Mahmud oğlu 40

Kalfas1 Kirca Mehmed bin

Kumral Mahmud

Sakallı

Ekmekçi Uzunca Kâhya oğlu 18

Kalfası Boylu Mehmed bin

Ter Kara İbrahim

Biyıklı

Ekmekçi Uzunca Tahir oğlu Ali bin 17

Kalfas1 Boylu Tahir

Şabb-1

Emred

Ekmekçi Orta Boylu Küçük oğlu Ali 25

Kumral bin Halil

Biyıklı 


\section{N Kişinin Geldiği Yer ve \\ $\mathbf{0}$}

\section{Yakınlık Derecesi \\ ve \\ Maiyetinin \\ Niteliği ve \\ Görevi}

37 Muğla canininden gelmiştir Sene 61

38 Denizli Kazası canibinden gelmiştir Sene 59

39 Denizli Kazası canibinden gelmiştir Sene 60

40 Antakya canibinden gelmiştir Sene 61

41 Denizli Kazasından gelmiştir Sene 59 Buldanlı Sakin Ekmekçi Andreya yanında

42 İzmir canibinden gelmiştir Sene 51

43 İzmir canibinden gelmiştir Oğlu Sene 51

Nakil Güzelhisar Yarbaşı Mahallesine Sene 63

44 Isparta Kazasindan gelmiştir Sene 61

Sakin han-1 Çavuş

45 Isparta Kazasindan gelmiştir Sene 61

Sakin han-1 Çavuş

46 Isparta Kazasından gelmiştir Sene 61

Sakin han-1 Çavuş

47 Isparta Kazasından gelmiştir Sene 61

49 Antakya canibinden gelmiştir Sene 61

Kütüphane karşısında kadayıf̧̧ı dükkanında

48 Isparta canibinden gelmiştir Sene 58

\section{Mesleği Fiziksel özellikleri}

İsim

Yaș

\begin{tabular}{|c|c|c|c|}
\hline \multirow{2}{*}{$\begin{array}{l}\text { Ekmekçi } \\
\text { Kalfası }\end{array}$} & Orta Boylu & Çuluğ & \multirow[t]{2}{*}{22} \\
\hline & Kara & Osman & \\
\hline & Biylkl1 & Hasan bin Osman & \\
\hline Ekmekçi & Orta Boylu & Nalband Kara Ali & 16 \\
\hline Kalfasi & $\begin{array}{l}\text { Şabb-1 } \\
\text { Emred }\end{array}$ & oğlu Halil bin Ali & \\
\hline Ekmekçi & Uzunca & Kara hisarlı oğlu & \\
\hline Kalfasi & Boylu & Mehmed & \\
\hline & $\begin{array}{l}\text { Şabb-1 } \\
\text { Emred }\end{array}$ & Mehmed & \\
\hline Ekmekçi & Orta Boylu & Şaban & \\
\hline Kalfası & $\begin{array}{l}\text { Kumral } \\
\text { sakall }\end{array}$ & Süleyman & \\
\hline Ekmekçi & Orta Boylu & Kani oğlu Hasan & \\
\hline Tablekar & Kara & bin Mehmed & \\
\hline 1 & Biyıklı & & \\
\hline
\end{tabular}

Aşç

$\begin{array}{llll}\text { Uzunca } & \text { İbrahim } & \text { bin } & 56 \\ \text { Boylu } & \text { Mehmed } & & \\ \text { Kara sakallı } & & & \\ \text { Orta Boylu } & \text { Mustafa } & & 16\end{array}$

Şabb-1

Emred

Hamal Orta Boylu Tabur oğlu Hasan 40

Kara sakallı bin Ömer

Hamal Kisa Boylu Berber oğlu 40

Köse Sarı Mehmed bin

Sakallı İbrahim

Hamal Uzunca Hamza oğlu 18

Boylu Hamza bin

Ter Kara Mehmed

Biylklı

Hamal Orta Boylu Çırak oğlu 42 Kumral Mustafa bin sakall $\quad$ Mehmed

Lokmac1 Orta Boylu Şaban bin Ahmed 20 Ter Kara Bıyıklı

Hamal Uzun Boylu Kara Mehmed bin 42 Kara sakallı Mehmed 


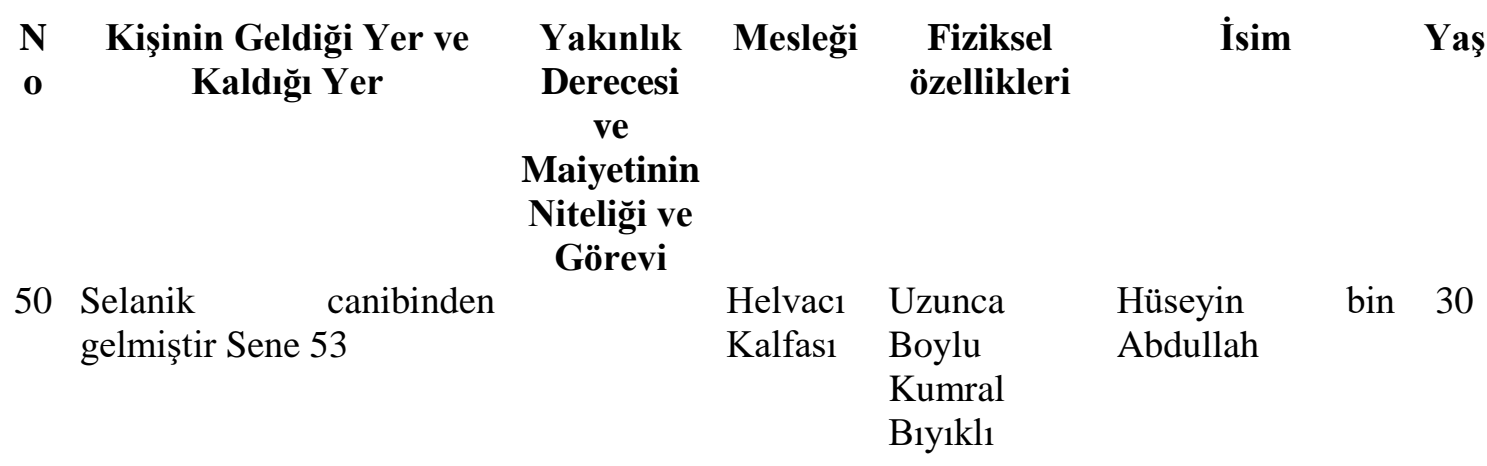

\section{Karye-i Hacı Ali Obası tabii Güzelhisar-ı Aydın bekaran-ı İslam ${ }^{101}$}

No

Kişinin Geldiği Yer

Mesleği

Fiziksel
Özellikleri

1 Nazilli Kazasından gelip işbu Buldurlu Ali'nin Orta Boylu karye-i mezkûrda Sene 57 Hizmetkâr1

Ter Biyıklı

İbrahim bin 23

2 Söke kazasına tabi Irgadlı

Köse oğlu Orta Boylu karyesinden gelmiştir Sene 57 Hizmetkârı Ter Bıyıklı

Abdullah

Osman bin 16

3 Yenipazar kazasında olub üç Mestan Kethüda Kısa Boylu

Osman

Mehmed bin 17 seneden beri karye-i mezkûrda Hizmetkârı

Ter Biyıklı

Mehmed hizmetkâr

4 Erzincan tarafindan olub İki İmam

Orta Boylu

Osman

Kara Sakallı

Efendi bin ücret ile imam olduğu Sene 58

Tahir

\section{Karye-i Kürtler tabii Güzelhisar-ı Aydın bekaran-ı İslam ${ }^{102}$}

$\begin{array}{ccc}\mathbf{N} & \text { Kişinin Geldiği } & \text { Mesleği } \\ \mathbf{0} & \text { Yer } & \\ 1 & \text { Erzincan tarafindan } & \text { İmam } \\ & \text { olub dört seneden } & \\ & \text { beri karye-i } & \\ & \text { mezkıurda ücet ile } & \\ & \text { İmam olduğu } & \\ 2 & \text { an-asıl Mihaliç } & \text { Çiftlik } \\ & \text { kazasindan olup } & \text { Müdürü } \\ & \text { der-Saadette } & \\ & \text { Türkmenzade } & \\ \text { tarafindan bir } & \\ \text { seneden beri karye- } & \\ \text { i mezkurda çiftlik } & \\ \text { müdürü olduğu } & \\ & \text { Sene 59 }\end{array}$

\section{Fiziksel \\ Özellikleri \\ Uzun Boylu \\ Kır Sakallı}

\section{Mehmed Efendi bin} Ahmed

Ali Ağa bin Halil

35

\footnotetext{
${ }^{101}$ BOA, NFS.d. 3013, s. 26.

102 BOA, NFS.d. 3013, s. 26.
} 


$\begin{array}{cccccc}\mathbf{N} & \text { Kişinin Geldiği } & \text { Mesleği } & \text { Fiziksel } & \text { İsim } & \text { Ya } \\ \mathbf{o} & \text { Yer } & & \text { Özellikleri } & & \text { ș } \\ 3 & \text { Rumelinden ... } & & \text { Orta Boylu } & \text { Memiş bin Mahmud } & 28 \\ & \text { Kazasından olub } & & \text { Kara Bıylklı } & & \end{array}$
çiftlik-i mezkûrda altı mahtan beri sakin olduğu Sene 60

\begin{tabular}{|c|c|c|c|c|c|c|}
\hline \multicolumn{7}{|c|}{ Karye-i Umurlu tabii Güzelhisar-ı Aydın bekaran-ı ehl-i İslam ${ }^{103}$} \\
\hline No & Kişinin Geld & ği Yer & Mesleği & $\begin{array}{l}\text { Fiziksel } \\
\text { Özellikleri }\end{array}$ & İsim & Yaş \\
\hline 1 & $\begin{array}{l}\text { Burdur Kazas1 } \\
\text { gelmiştir Sene } 61\end{array}$ & canibinden & $\begin{array}{l}\text { Pabuç } \\
\text { Dikiciliği } \\
\text { ticaretiyle }\end{array}$ & $\begin{array}{l}\text { Orta Boylu } \\
\text { Sarı Sakallı }\end{array}$ & $\begin{array}{l}\text { Hüseyin } \\
\text { Himmet }\end{array}$ & 36 \\
\hline 2 & $\begin{array}{l}\text { Burdur Kazas1 } \\
\text { gelmiştir Sene } 61\end{array}$ & canibinden & Pabuççu & $\begin{array}{l}\text { Orta Boylu } \\
\text { Kara Sakallı }\end{array}$ & Ahmed bin Ali & 42 \\
\hline 3 & $\begin{array}{l}\text { İneovas1 Kazas1 } \\
\text { gelmiştir Sene } 60\end{array}$ & canibinden & Demirci & $\begin{array}{l}\text { Orta Boylu } \\
\text { Köse Kara } \\
\text { Sakallı }\end{array}$ & Hasan bin Ali & 38 \\
\hline
\end{tabular}

\section{Karye-i Serçe tabii Güzelhisar-ı Aydın bekaran-ı ehl-i İslam ${ }^{104}$}

No Kişinin Geldiği Yer

Mesleği

1 Rodos canibinden gelmiştir Bahçıvan Sene 46

2 Girid Adası canibinden Bahçıvan gelmiştir Sene 49

3 Girid Adası canibinden Bahçıvan gelmiştir Sene 57

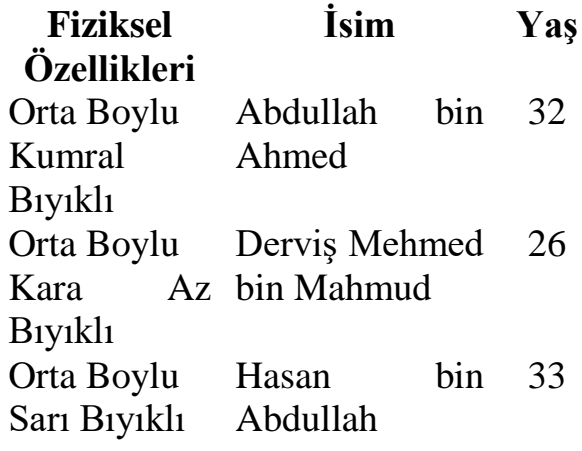

\section{SONUÇ}

Tarihsel süreçte birçok medeniyete ev sahipliği yapmış olan Aydın Güzelhisarı, Aydınoğluları Beyliği döneminde Tire ve Ayasuluğ gibi ticari merkezlerin gölgesinde kalarak daha çok küçük bir kasaba görünümündedir. Bu durumunu Osmanlı egemenliğine girdiği 1426'dan XVII. yüzyıl sonlarına kadar sürdüren Güzelhisar, gelişen ticaretin etkisiyle birlikte bu yüzyıldan itibaren Aydın Sancağı'nın önemli yerleşim yerleri arasında yer almaya başlamıştır. XVIII. ve XIX. yüzyıllarda uluslararası ticarette giderek önemi artan İzmir'in durumu Aydın Güzelhisarı'nın durumunu da etkilemiştir. İzmir' in hinterlandı konumundaki Güzelhisar, XIX. yüzyılın başlarında Tire'yi geride bırakarak Aydın Sancağı'nın merkezi haline gelmiştir.

$\mathrm{Bu}$ dönemde daha çok Cihanoğulları ve Karaosmanoğulları gibi ayan ailelerinin yönetiminde söz sahibi olduğu Aydın Güzelhisarı II. Mahmut dönemindeki merkezileştirme

\footnotetext{
103 BOA, NFS.d. 3013, s. 27.

104 BOA, NFS.d. 3013, s. 27.
} 
politikalarından etkilenmiştir. 1816 senesinde Aydın mütesellimliğini yürüten Karaosmanoğlu Hacı Hüseyin Ağa'nın vefatından sonra daha çok merkezden atanan mutasarrıf paşalar tarafından yönetilmiştir. Ancak gerek Aydın Sancağı'nda 1828-1829 yılları arasında meydana gelen Atçalı Kel Mehmet Ayaklanması gerekse 1832-1833 senelerinde Mısır Valisi Mehmet Ali Paşa'nın oğlu İbrahim Paşa tarafından atanan mütesellimler tarafından yönetilmesi idari anlamda karıșıklıklara neden olmuştur. Mısır birliklerinin Anadolu'dan çekilmesinden sonra Anadolu Eyaleti'nde yapılan değiş̧ikliklerden Aydın Güzelhisarı da etkilenmiştir. Bir bakıma askeri nitelikli bir idari teşkilat olarak oluşturulan müşirlik sistemiyle Aydın, Saruhan, Sığla ve Menteşe sancakları birleştirilerek Aydın Müşirliği oluşturulmuştur. XIX. yüzyılın başından beri Sancağı'nın merkezi olan Güzelhisar, bu tarihten itibaren Aydın Müşirliği'nin merkezi konumuna yükselmiştir. Müşirliğe ise 1833 yılından itibaren Aydın Sancağı'nın muhassılı sıfatıyla görevde bulunan Karaosmanoğlu Yakup Paşa atanmıştır.

Karaosmanoğlu ailesinden olan Yakup Paşa, 1833-1848 yılları arasında muhassıllık, müşirlik vs. farklı unvanlarla getirildiği Aydın Güzelhisarı'nın yönetimde bulunmuş önemli bir şahsiyettir. Yakup Paşa ,yöneticiliğinin dışında Aydın Güzelhisarı'nın sosyo-ekonomik ve kültürel anlamda gelişmesinde de önemli rol oynamıştır. Aydın Güzelhisarı'nda yaptırmış olduğu han, çeşme gibi hayır eserleriyle kentin imarına da katkı sağlamıştır.

Karaosmanoğlu Yakup Paşa'nın Aydın Müşirliği sırasında 1845'de gerek kendi mahiyeti gerekse Aydın defterdarı, hâkimi ve zabtiye teşkilatı gibi Aydın Güzelhisar'ının idari kadrosunun yanı sıra Kaza merkezindeki medrese ve hanlarda kalan kişilerle dükkân ve kahvehanelerde kalan bekâr nüfusa yönelik bir nüfus sayımının yapılması dikkate değerdir. II. Mahmut döneminde başlayan modern anlamdaki nüfus sayımlarında genellikle yerleşim birimlerindeki erkek nüfusun sayımının yapıldığı görülürken çalışmaya konu olan 3013 numaralı Aydın Güzelhisar Kazası nüfus defterinde bunun yerine kaza yönetiminden sorumlu idari kadrolara ilişkin ayrı bir defterin tutulması gerek Güzelhisarı Aydın'nın gerekse Karaosmanoğlu Yakup Paşa'nın konumuyla ilgili olmadır. Kavas, kâtip dividdar, aşçı, hazine kâtibi, kilerci, mirahor vs. farklı görevlerde 72 kişilik mahiyetiyle Yakup Paşa Aydın'ın idaresinden sorumludur. Her ne kadar Tanzimat'ın ilanından sonra Osmanlı' da ayanlık kurumunun tamamen ortadan kaldırıldığına dair görüşler olsa da en azından Aydın Güzelhisarı için bu durumun geçerli olmadığı ifade edilebilir. Bu dönemde aile üyeleri Yakup Paşa örneğinde olduğu gibi muhassıllık, müşirlik gibi resmi görevlerle idari kadrolarda yer almaya devam etmektedirler.

Yakup Paşa'nın mahiyeti dışında nüfus defterinden sayımın yapıldığı tarihte Aydın defterdarı Raşid Bey'in ve Aydın Eyaleti emval kâtibi Mustafa Faik Efendi bin Mehmet Emin Efendi'nin 14'er kişilik mahiyetiyle Aydın Güzelhisar'nın mali işlerinden sorumlu oldukları görülmektedir. 1845 yılında Aydın hâkimi olan Çarşambalızade el-Hac Said Efendi bin Mehmed Efendi'nin yedi kişilik mahiyetinin yanı sıra Aydın zabtiye hizmetinde görevli toplamda 52 kişilik bir süvari piyade bölüğünün de bulunduğu nüfus defterindeki bir diğer önemli bilgilerdir.

1845 yılı nüfus defterinde Aydın Güzelhisarı'nın idari kadrosunun dışında Güzelhisar'da bulunan medrese ve burada kalan kişilere dair önemli bilgiler de bulunmaktadır. Aydın Güzelhisar Kazası merkezinde ve kazaya bağlı bazı köylerde Cihanzade, Osmanzade nam-1 diğer Nasuh Paşa, Kocaavlu, İbrahim Ağa, Çiçekli, Veysi Paşa, Kubbeli Mescid, Cami-i Kebir, Dayızade, Alihan, Eski Yeni, Abacızade, Ramazan Paşa, Yukarı ve Aşağı Zeynzade, Bey, Zincirli nam-1 diğer Kozdibi, Çelik Paşa, Ağaçarası nam-1 diğer Ahmet Paşa, Çarıkçızade, Hacı Suhtezade, Cincinlizade, Çilingirzade, Ali Hoca, İhtisab, Yağıroğlu, Akmescid, Posacıoğlu, Dükkanönü, Zincirli nam-1 diğer Yarbaşı isimli olmak üzere toplamda 29 medresede 250 kişinin kaydı bulunmaktadır.

Nüfus defterindeki ilmi hareketliliği gösteren medreselere ilişkin kayıtların yanı sıra kaza dâhilindeki hanlar ve bu hanlarda kalan kişilere ait kayıtlarda Tanzimat'in hemen sonrasında 
Aydın Güzelhisarı'nın kültürel ve ticari canlılığını gösteren en önemli delillerdir. Aydın Güzelhisarı'na gelen kişiler Balcıoğlu Hanı, Cihanzade Hanı, Deliler Hanı, Hacı Ali Efendi Hanı, Hacı Mustafa Efendi Hanı, İnce Bayraktar Han, Köprübaşı Hanı, Kör Keçiler Han1, Körük = Gödek Hanı, Kurşunlu Han, Mimar Han, Mustafa Paşa Hanı, Osmanzade Hanı, Şamlıoğlu Hanı, Yakup Paşa Hanı ve Muytab Hanı gibi hanlarda konaklamışlardır.

Ayrıca defterden, hanların dışında çeşitli nedenlerle farklı meslek gurubundaki bekâr insanların Aydın Güzelhisarı'na gelerek kahvehane ve dükkânlarda ya da çevre köylerde konakladıklarına dair bilgileri de elde edebiliriz. Çoğunluğunu çevre sancak ve kazalar ile Girit, Rodos gibi adalardan gelen insanların oluşturduğu kişiler, demirci, dülger, helvacı, pabuşçu, eskici, imam, rençber çulha, muytab, dikici, şekerci, hamal, kahveci, ırgat, ekmekçi vs. çok çeşitli işkollarıyla Aydın Güzelhisarı'ının iş gücü açığını gidermektedir.

1845 yılı Aydın Güzelhisar Kazasına ait nüfus defterindeki veriler Kazanın idari, sosyoekonomik yapısıyla birlikte ticari hayatına ve ilmi hayatına ilişkin önemli veriler sunmaktadır.

\section{KAYNAKÇA}

Devlet Arşivleri Başkanlığı Osmanlı Arşivi (BOA), Nüfus Defterleri (NFS.d.), Defter Kodu: 3013.

Afyoncu, Erhan, Osmanlı Devlet Teşkilatında Defterhane-i Amire (XVII-XVIII. Yüzyıllar, Ankara 2014,), Türk Tarih Kurumu, Ankara 2014.

Akın, Himmet, Aydınoğulları Tarihi Hakkında Bir Araştırma, Ankara Üniversitesi Basım Evi, Ankara 1968.

Barkan, Ömer Lütfü, “Türkiye'de İmparatorluk Devirlerinin Nüfus ve Arazi Tahrirleri ve Hakana Mahsus İstatistik Defterleri”, IÜ İktisat Fakültesi Mecmuası, 2/1, 1940-41, ss. 20-59

Başaran, Mehmet, Sarıbey Haykıran, Aysun, Özçelik, Ali, Atçalı Kel Mehmed Efe, Batı Anadolu'da Eşklyalık ve Zeybeklik, Kitap Yayınevi, İstanbul 2018.

Baykara, Tuncer, Anadolu'nun Tarihi Coğrafyasına Giriş, I Anadolu'nun İdari Taksimatı, Türk Kültürü Enstitüsü Yayınları, Ankara 1988.

Behar, Cem, "Osmanlı Nüfus İstatistikleri ve 1831 Sonrası Modernleşmesi”, Osmanlı Devleti'nde Bilgi ve İstatistik, (Ed. H. İnalcık-Ş. Pamuk), Devlet İstatistik Enstitüsü, Ankara 2000, ss. 63-72.

Çadırcı, Musa, "Anadolu'da Redif Askeri Teşkilâtının Kuruluşu”, Tarih Araştırmaları Dergisi, S. VIII- XII / 14-23 Sene 1970-1974 (1975), ss. 63-75.

Çelik, Bülent, Demir, Tanju, Osmanlı Devleti'nde Bir- İdari- Mali Yeniden Yapılanma Örneği Aydın Muhassilliğl (XVII. ve XVIII. Yüzylllar), Adnan Menderes Üniversitesi Yayınları, Aydin 2010.

Durma, Abdulhalim, Evliyalar Şehri Aydın.

Evliyâ Çelebi, Seyahatnâmesi, IX. Kitap, Yücel Dağl1, Seyit Ali Kahraman, Robert Dankoff, Yap1 Kredi Yayınları İstanbul 2005. 
Faroqhi, Suraiya, "Sixteenth Century Periodic Markets in Various Anatolian Sancaks: İçel, Hamid, Karahisar-1 Sahib, Kütahya, Aydın, and Menteşe", Journal of Economic and Social, History of the Orient, c. 22, S. 1, 1979, ss. 32-79.

Gencer, Fatih, “İbrahim Paşa'nın Anadolu'yu İstilası, (1832-1833)”, Uluslararası Sosyal Araştırmalar Dergisi, c. 9, S. 42, Şubat 2016, ss. 641-657.

Gökbilgin, M. Tayyib, “Kara Üveys Paşa'nın Budin Beylerbeyliği (1578-1580)”, Tarih Dergisi, c. II, S. 3-4, İstanbul 1952, ss. 17-34.

Hızlı, Mefahil, "Kuruluşundan Osmanlılara Kadar Medreseler”, Uludă̆ Üniversitesi ilahiyat Fakültesi Dergisi, c. 2, S. 2, Bursa 1987, ss. 273-281.

İbn Battûta Seyahatnamesi, c. I, Çev. A. Sait Aykut, Yap1 Kredi Yayınları, İstanbul.

İlknur, Gürgen, XV. - XVI. Yüzyıllarda Güzelhisar Kazası, Basılmamış Yüksek Lisans Tezi, Celal Bayar Üniversitesi, Sosyal Bilimler Enstitüsü, Manisa 2015.

Karal, Enver Ziya, Osmanlı İmparatorluğu’nda İlk Nüfus Sayımı 1831, Devlet İstatistik Enstitüsü, Ankara 1997.

Kocakaplan, Saim Çağrı, Temettüât Defterleri Çerçevesinde Silistre Kazası'nın İktisadî ve Sosyal Yapısı, Basılmamış Yüksek Lisans Tezi, Marmara Üniversitesi, Sosyal Bilimler Enstitüsü, İstanbul 2007.

Kuneralp Sinan, Son Dönem Erkân ve Ricali (1839-1922) Prosopografik Rehber, İSíS, İstanbul 1999.

Nagata, Yuzo, Tarihte Âyânlar Karaosmanoğlu Üzerinde Bir İnceleme, Türk Tarih Kurumu, Ankara 1997.

Ortaç, Hilal, Tapu Tahrir Defterlerine Göre 16. Yüzyılda Güzelhisar, Aliağa Belediyesi Kültür Yayınları, Ankara 2018.

Öz, Mehmet, “Tahrir”, DİA, c. 39, İstanbul 2010, ss. 425-429.

Özkan, Mustafa Kenan, "Aydın Valisi Yakup Paşanın Kuyucak’da Yaptırdığı Eserler”, Cumhuriyetin 75. Yılı Milet Müzesi Yıllı̆g, S. 1, Söke 1997, ss. 21-27.

Pullukçuoğlu Yapucu, Olcay, Modernleşme Sürecinde Bir Sancak Aydın, Kitap Yayınevi, İstanbul 2007.

Pullukçuoğlu Yapucu, Olcay, Özgün, Cihan, "Batı Anadolu'nun Yol Ağı Araştırmaları III, İzmir'in Ardalanında Kervan Yolları", Tarih İncelemeleri Dergisi, c. XXVI, S. 2 Aralık 2011, ss. 527-549.

Sarıbey Haykıran, Aysun, "1831 Tarihli Nüfus Sayımında Aydın Güzelhisar Kazası Cami-, Atik Mahallesi”, Yenifikir Uluslararası Hakemli Akademik Fikir Araştırma Dergisi , S. 22 (Temmuz 2019).

Sarıbey Haykıran, Aysun, Başaran, Mehmet, "Modernleşme Sürecinde Aydın'da Yönetim Olgusu, Tarihsel Süreçte Aydın, Ed. Günver Güneş, Aydın Belediyesi Kültür Yayınları, Aydin 2012. 
Sarıbey Haykıran, Aysun, Can Tunalı, Ayten, "XIX. Yüzyılda Aydın”, Aydın Il Tarihi, Aydın İl Kültür Müdürlüğü Yayınları, Aydın 2006.

Sarıbey, Aysun, XIX. Yüzyılın İlk Yarısında Aydın'da Yönetim, Yayımlanmamış Yüksek Lisans Tezi, Adnan Menderes Üniversitesi, Sosyal Bilimler Enstitüsü, Aydın 2006.

Şeker, Mehmet, "Aydınoğullarının Kültür Hayatı ve Türkçeciliğì”, Uluslararası Batı Anadolu Tarih Kültür ve Medeniyeti Sempozyumu I Aydınoğulları Tarihi Bildiriler, Ed. Prof. Dr. Mehmet Ersan, Prof. Dr. Mehmet Şeker, Prof. Dr. Cüneyt Kanat, Türk Tarih Kurumu, Ankara 2013.

Şeker, Mehmet, İbn-i Batuta'ya Göre Anadolu'nun Sosyal- Kültürel ve İktisadî Hayatı ile Ahîlik, II. Bask1, Kültür Bakanlığı Yayınları, Ankara 2000.

Taş, Çiğdem, Maârif Salnamelerine Göre 20. Yüzyıl Başlarında (1898-1904) Aydın Vilâyeti'nde Eğitim, Basılmamış Yüksek Lisans Tezi, Afyon Kocatepe Üniversitesi, Sosyal Bilimler Enstitüsü, Afyon 2006.

Türkiye'de Vakıf Abideler ve Eski Eserler, Vakıflar Genel Müdürlüğü Yayınları, 2. Baskı, Ankara 1983.

Uluçay, Çağatay, Atçalı Kel Memed, As Matbaası, İstanbul 1968.

Uzunçarşı11, İsmail Hakkı, "Mısır Valisi Mehmet Ali Paşa Kuvvetleri Tarafindan Saruhan, Aydın ve İzmir'in İsgaline Dair Belgeler”, Belleten, c. XLVII, S. 185, Ankara 1984, ss. 1-29. 


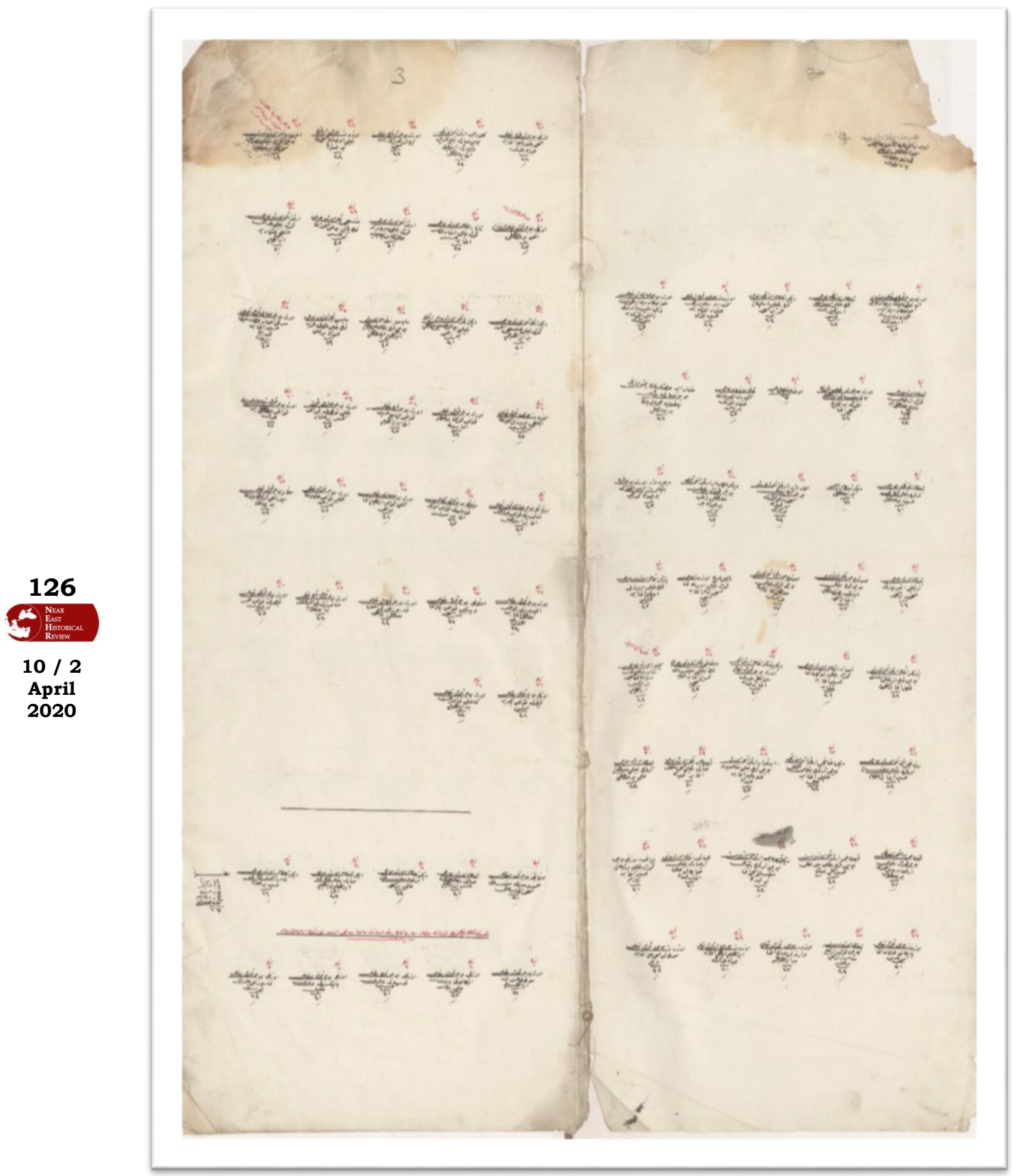

Belge 1: 3013 Nolu Nüfus Defteri

Near East Historical Review 


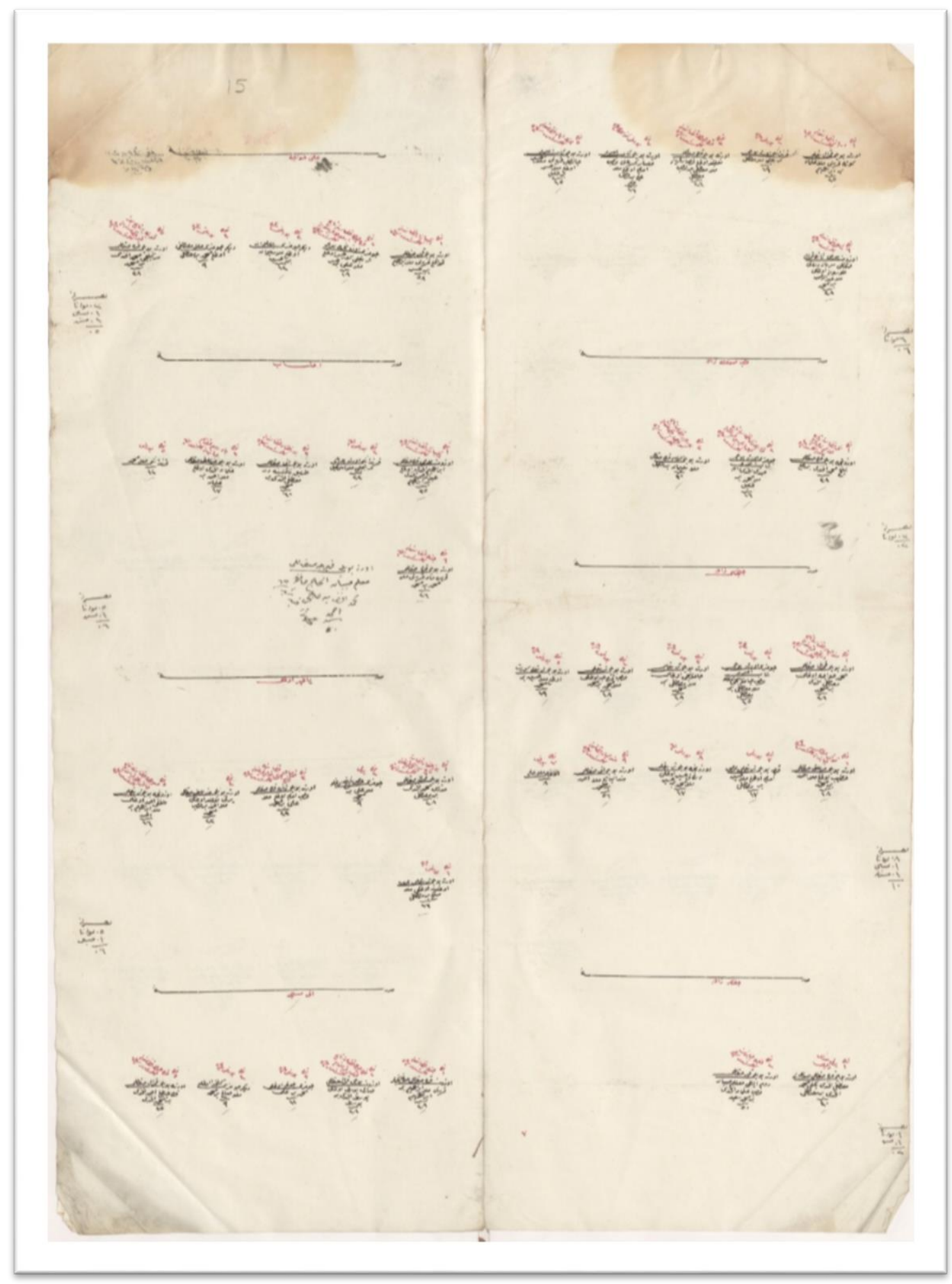

Belge 2: 3013 Nolu Nüfus Defteri 


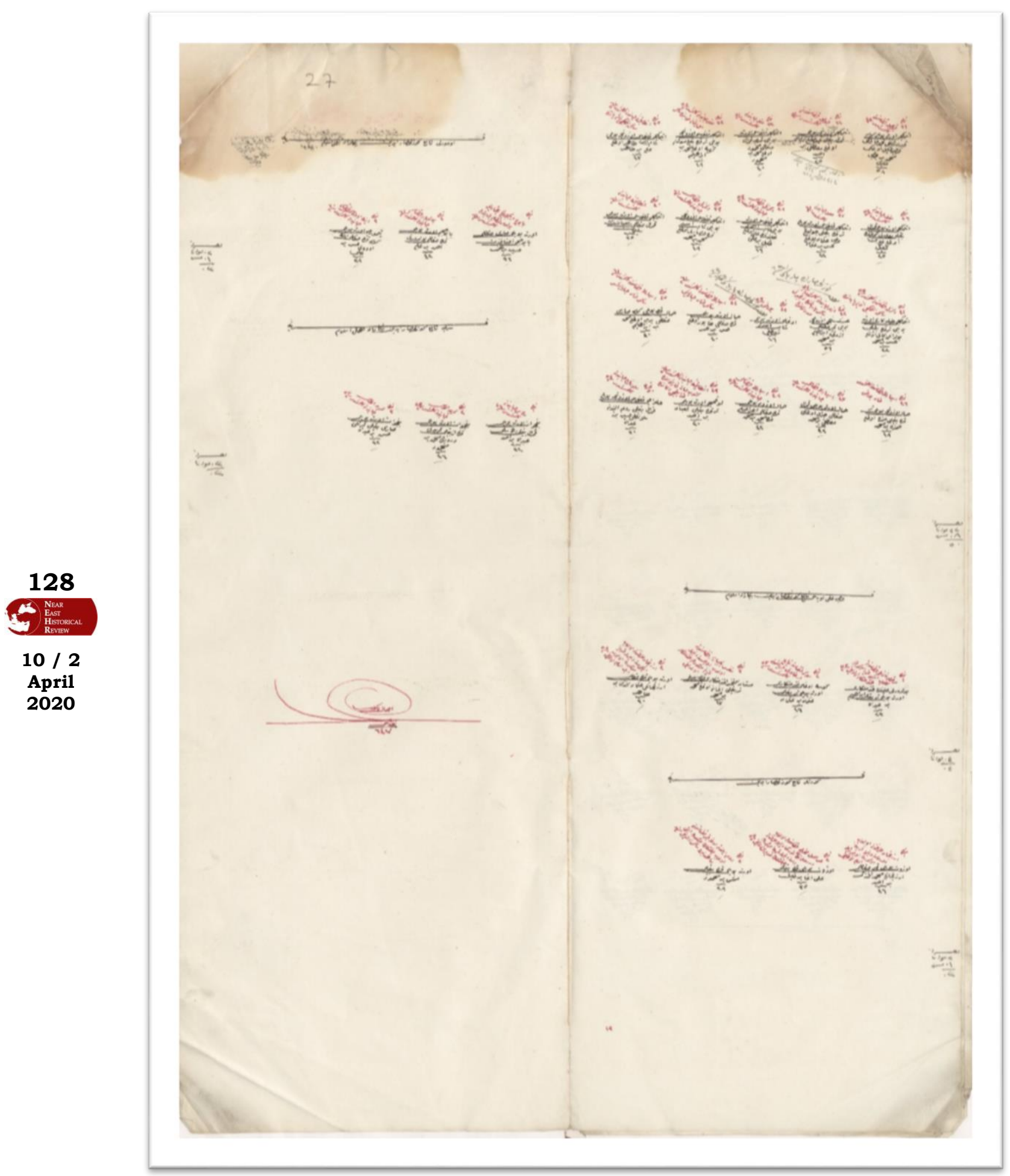

Belge 3: 3013 Nolu Nüfus Defteri

Near East Historical Review www.nehrreview.com 